\title{
CURVULARIA LUNATA INTERAKCIÓJÁNAK VIZSGÁLATA A TERMÉSZETES IMMUNVÁLASZ SEJTJEIVEL
}

DOKTORI ÉRTEKEZÉS

TóTH ESZTER JUDIT

TÉMAVEZETŐK

DR. PAPP TAMÁS, EgYeTEMI dOCENS

Prof. Dr. VÁgVölgyi Csaba, egyetemi tanár

BIOLÓGIA DOKTORI ISKOLA

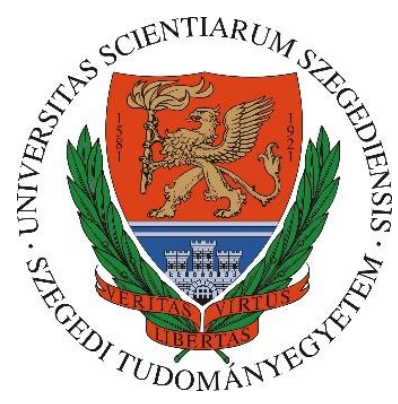

SZEGEDI TUDOMÁNYEGYETEM

TERMÉSZETTUDOMÁNYI ÉS INFORMATIKAI KAR

MiKrobiológiai TANSZÉK

2019 


\section{Tartalomjegyzék}

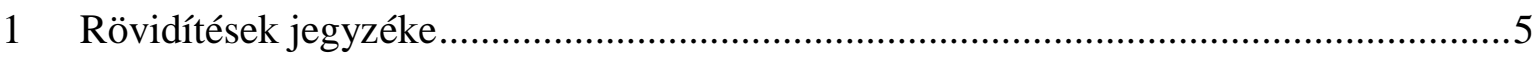

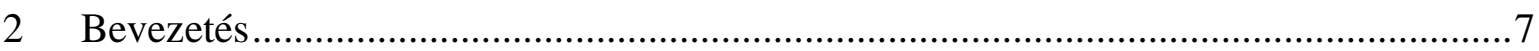

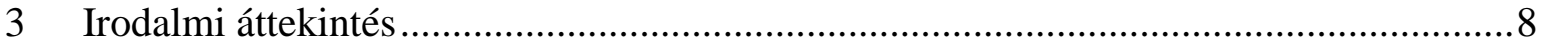

3.1 A Curvularia nemzetség általános jellemzése ......................................................

3.1 A felbukkanó gombafertőzések jelentősége .........................................................

3.2 A Curvularia fajok által okozott fertőzések általános jellemzése és epidemiológiája

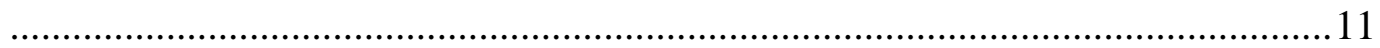

3.2.1 Felszíni fertőzések .................................................................................11

3.2.2 Légutakat érintő megbetegedések ............................................................11

3.2.3 Központi idegrendszeri megbetegedések ………………..............................12

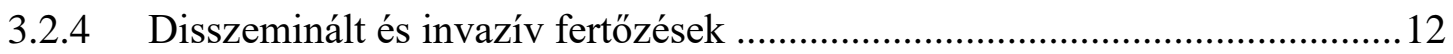

3.3 A Curvularia fajok patogenitása.........................................................................13

3.4 A Curvularia lunata lehetséges virulencia faktorai..............................................13

3.4.1 A melanin szerepe a patogenezisben...........................................................14

3.4.2 A haloperoxidáz enzimek jellemzése és szerepe............................................15

3.5 Az A. fumigatus általános jellemzése és az általa okozott megbetegedések .........18

3.6 A gombák elleni természetes immunválasz - effektor sejtek .................................18

3.6.1 Monociták ...........................................................................................19

3.6.1.1 A monociták szerepe a patogén fonalas gombák elleni védekezésben .21

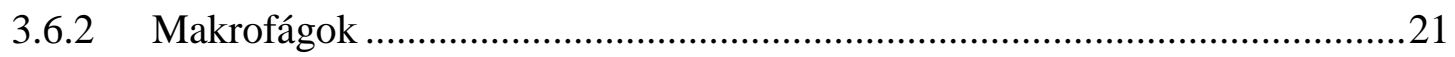

3.6.2.1 A makrofágok szerepe a patogén fonalas gombák elleni védekezésben

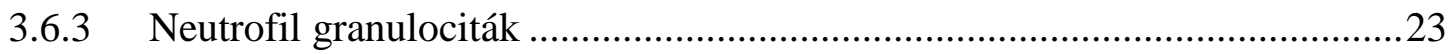

3.6.3.1 A neutrofil granulociták szerepe a patogén fonalas gombák elleni

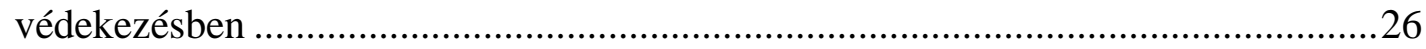

3.7 A THP-1 sejtvonal - a monocita-makrofág sejtek modellrendszere ………...........28

3.8 A neutrofil granulociták modellrendszerei ........................................................29

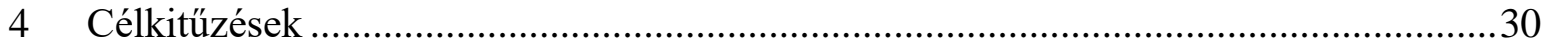

5 Anyagok és módszerek.....................................................................................

5.1 Az alkalmazott gombatörzsek: tenyésztés, spóraszuszpenzió készítése ………......31 


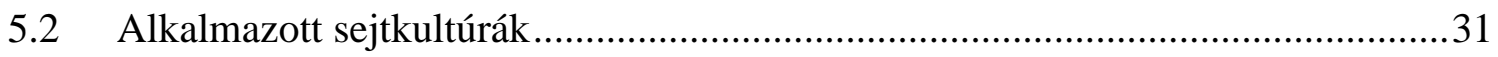

5.3 Alkalmazott tápközegek, oldatok, reagensek és pufferek.......................................31

5.4 Gombatörzsek tenyésztése, konídium-szuszpenzió készítése .................................32

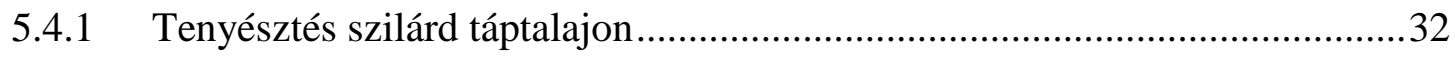

5.4.2 Tenyésztés folyékony tápoldatban, $\mathrm{H}_{2} \mathrm{O}_{2}$ indukció........................................33

5.5 Sejtvonalak tenyésztése, primer sejtek izolálása …………………………….........33

5.5.1 THP-1 sejtvonal tenyésztése és differenciáltatása............................................33

5.5.2 Primer neutrofil granulociták izolálása ……………………………………......33

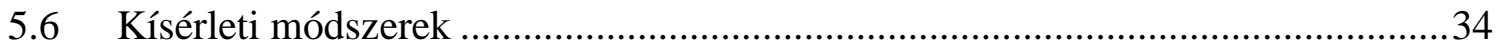

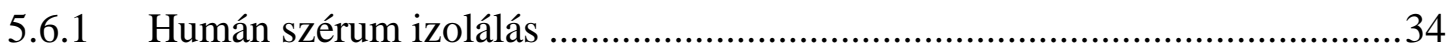

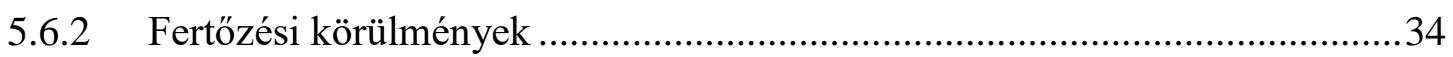

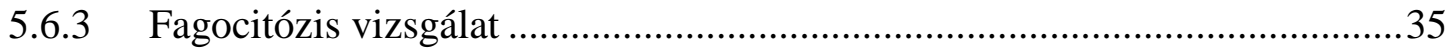

5.6.4 Enzimhez kapcsolt immunoszorbens vizsgálatok (ELISA) ……………….....35

5.6.5 Gomba életképesség meghatározás ..............................................................36

5.6.6 Mieloperoxidáz (MPO) aktivitás mérése …………………………………......37

5.6.7 Reaktív oxigéngyökök (ROS) mérése .............................................................37

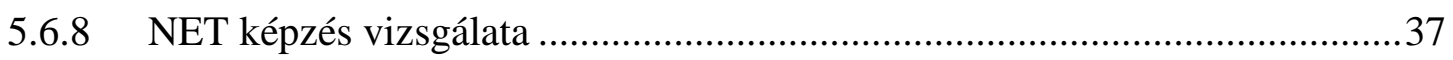

5.6.9 Az extracelluláris $\mathrm{pH}$ meghatározása .............................................................38

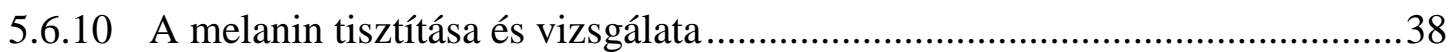

5.6.11 RNS izolálás, cDNS szintézis és kvantitatív valós idejü reverz transzkripció (qRT) PCR analízis .....................................................................................................

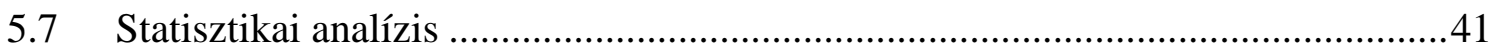

5.8 In silico szekvencia elemzés ................................................................................41

6 Eredmények és értékelésük ..................................................................................42

6.1 Monociták válasza Curvularia izolátumokra ........................................................42

6.1.1 A THP-1 sejtek C. lunata konídiumokra adott válasza...................................42

6.1.2 A THP-1 sejtek Curvularia hifákra adott válasza ............................................47

6.2 Makrofágok válasza Curvularia izolátumokra ...................................................55

6.3 Neutrofil granulociták válasza Curvularia lunata-ra............................................57

6.3.1 A melanin, mint antioxidáns jelenléte ................................................................64

6.3.2 Az extracelluláris környezet savasodása ..........................................................64 


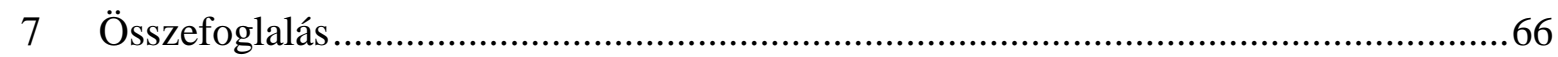

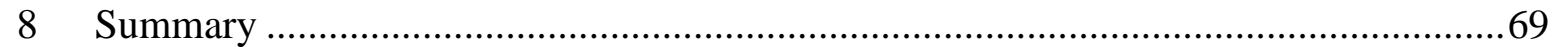

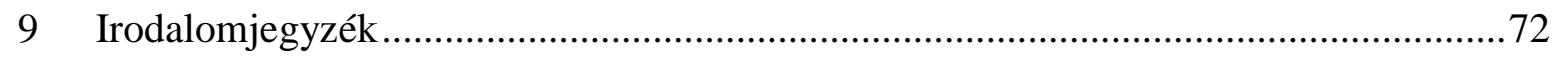

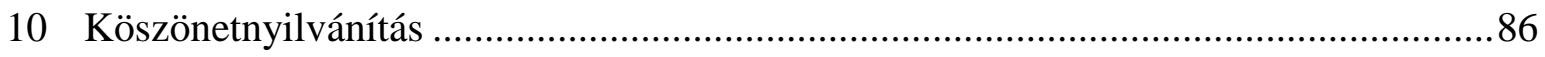

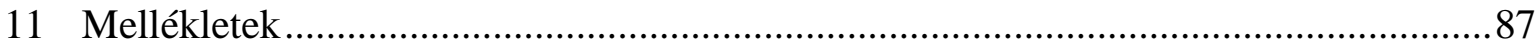




\section{Rövidítések jegyzéke}

\begin{tabular}{|c|c|}
\hline$\Delta^{1} \mathrm{O}_{2}$ & szinglet oxigén \\
\hline BSA & marha szérum albumin (bovine serum albumin) \\
\hline CARD & caspase-recruitment domain \\
\hline $\mathrm{CD}$ & differenciációs klaszter (cluster of differentiation) \\
\hline CGD & krónikus granulomatózus betegség (chronic granulomatous disease) \\
\hline CLR & C-típusú lektin receptor \\
\hline $\mathrm{CPO}$ & C. inaequalis nem-hem kloroperoxidázát \\
\hline $\mathrm{CR}$ & komplement receptor (complement receptor) \\
\hline DHN & dihidroxinaftalén \\
\hline DMSO & dimetil-szulfoxid \\
\hline DOPA & o-dihidroxifenilalanin \\
\hline ELISA & enzimkötött immunoszorbens próba (enzyme-linked immunosorbent \\
\hline & 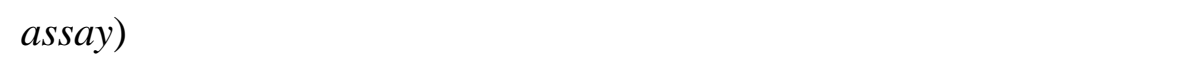 \\
\hline GPCR & G-protein kapcsolt receptor \\
\hline $\mathrm{H}_{2} \mathrm{O}_{2}$ & hidrogén peroxid \\
\hline HLADRA & HLA II osztályú hisztokompatibilitási antigén, DR alfa lánc \\
\hline $\mathrm{HOCl}$ & hipoklórossav \\
\hline HPO & haloperoxidáz \\
\hline IL & interleukin \\
\hline LPS & lipopoliszacharid \\
\hline MHC & fö hisztokompatibilitási komplex (major histocompatibility complex) \\
\hline MPO & mieloperoxidáz \\
\hline MTT & 3-(4,5-dimetil tiazol-2-il)-2,5-difenil-tetrazólium-bromid \\
\hline NADPH & nikotinamid-adenin-dinukleotid-foszfát \\
\hline NET & neutrofil extracelluláris csapda (neutrophil extracellular trap) \\
\hline $\mathrm{NF} \kappa \mathrm{B}$ & nukleáris faktor $\kappa \mathrm{B}$ \\
\hline NLR & NOD-like receptor (NOD-szerü receptor) \\
\hline NLRC3 & $\begin{array}{l}\text { NLR család CARD domént tartalmazó fehérje } 3 \text { (NLR family CARD } \\
\text { domain-containing protein 3) }\end{array}$ \\
\hline NOD & nukleotid oligomerizációs domén \\
\hline
\end{tabular}


$\mathrm{O}_{2}^{-} \quad$ szuperoxid gyök

OD optikai denzitás

PAP2 2-es típusú foszfatidil-sav foszfatáz

PBS foszfát pufferelt sóoldat (phosphate buffered saline)

PCR polimeráz láncreakció (polimerase chain reaction)

PMA forbol-mirisztil-acetát

PTFE poli(tetrafluoroetilén)

qRT-PCR kvantitatív valós-idejü polimeráz láncreakció

ROS reaktív oxigén fajták (reactive oxigen species)

RPMI 1640 sejttenyésztése alkalmas komplex tápoldat elnevezése (Roswell Park Memorial Institute)

Th segítő T-sejt (T helper)

THP-1 humán monocita-szerü sejtvonal elnevezése (Tohoku Hospital Pediatrics-1)

TLR Toll-szerü receptor (Toll-like receptor)

TNF- $\alpha \quad$ tumor nekrózis faktor $\alpha$ 


\section{Bevezetés}

Az opportunista patogén gombák által okozott fertőzések száma évről évre nő, az Aspergillus nemzetség tagjai mellett új fajok is felbukkannak, amely fajok által okozott megbetegedések kezelése megfelelő szakirodalmi adatok és tapasztalat hiányában nehézkes, gyakran csak mütéti úton lehetséges. Az immunszuppresszált betegek különösen kitettek az opportunista patogének általi fertőzéseknek, amelyek halálozási aránya ezekben az esetekben igen magas. Az immunszuppresszió számos modern orvostudományi eljárásnál nélkülözhetetlen (pl. transzplantáció, rákos megbetegedések), ezért e területek fejlődésével a társadalom veszélyeztetett rétege is bővül.

A fent említetteknek megfelelően, az utóbbi években megnőtt a nem-Aspergillus opportunista humánpatogén fonalas gombák vizsgálatával foglalkozó tanulmányok száma. Ezen csoportba tartoznak a Curvularia fajok, amelyek egyéb melanizált gombákhoz hasonlóan úgynevezett feohifomikózisok kialakítására képesek. A betegség egészséges emberekben föképp lokális fertőzésként jelenik meg, azonban immunszuppresszált betegekben invazív szisztémás mikózis is kialakulhat.

A Curvularia fajok által okozott megbetegedések immunológiai hátteréről, a felismerési mechanizmusokról, a kiváltott immunválaszról kevés információ áll rendelkezésünkre, ezért jelen dolgozat célja a Curvularia izolátumokkal, elsősorban a $C$. lunata-val szembeni immunválasz vizsgálata. A dolgozatban három, a veleszületett immunitáshoz tartozó sejtcsoport, a monociták, a makrofágok és a neutrofil granulociták interakcióját vizsgáltuk a gombatörzsekkel és összevetettük azt az A. fumigatus esetében tapasztalt adatokkal.

A Curvularia fajok erősen melanizált konídiumokkal és hifákkal rendelkeznek. A melanin virulenciában betöltött szerepét más fajok esetében már vizsgálták, azonban az eredmények alapján a pigment fajonként eltérő mértékben befolyásolja a megbetegítő képességet és a gazdaszervezeten belüli túlélést. Kísérleteink során a melanin-bioszintézis gátlásával modelleztük a melanin fagocitózist és monocita érést befolyásoló szerepét. 


\section{Irodalmi áttekintés}

\subsection{A Curvularia nemzetség általános jellemzése}

A Curvularia nemzetség a Pleosporaceae családba (Ascomycota, Pleosporales) sorolható, melynek nevezéktana és taxonómiája a közeli rokon Bipolaris nemzetséggel együtt zavaros és gyakran változott. 1999-ben Berbee és munkatársai (1999) ITS (a magi riboszómális RNS kódoló régió köztes átíródó szekvenciája), $5.8 \mathrm{~S}$ rRNS és gpd (glicerinaldehid-3-foszfát dehidrogenáz) szekvenciák alapján a teleomorf Cochliobolus nemzetség anamorf alakjait két csoportba osztotta. Eszerint az 1. csoport tartalmazta az erősen növénypatogén fajokat, melyek jellegzetes szaporító képlete a nagy, „kenu” alakú konídium. Ezen fajok mindegyike a Bipolaris nemzetségbe tartozott. A 2. csoport genetikailag és morfológiailag is diverzebb volt, a Bipolaris és a Curvularia nemzetségbe sorolt anamorf fajok egyaránt tartoztak ide. Ezek konídiuma általában rövid, egyenes vagy hajlott. A 2. csoportra már ezen vizsgálat alapján javasolták az egységes Curvularia elnevezést. Később Manamgoda és munkatársai (2012) részletesebb molekuláris filogenetikai vizsgálata is ugyanerre az eredményre vezetett. Így jelenleg az 1. csoportra a Bipolaris, a 2. csoportra a Curvularia nemzetségneveket alkalmazzák. Humánpatogén törzsek csak a 2. csoportban, tehát a Curvularia nemzetségben találhatók (da Cunha és mtsi. 2013, Madrid és mtsi. 2014). Ennek ellenére a klinikai feljegyzésekben gyakran még mindig Bipolaris-ként azonosítják a fertőzésből származó Curvularia izolátumokat.

A Curvularia nemzetség jelenleg körülbelül 80 fajt foglal magába. A lassan növő telepek sötéten pigmentáltak, barna vagy szürkés színüek, lehetnek vattaszerüek vagy lapítottak. A konídiumok szeptáltak, egyenesek vagy hajlottak, utóbbi esetben az egyik sejt megnagyobbodása okozza a jellegzetes görbületet, melyröl a nemzetség a nevét is nyerte. Erősen melanizáltak, méretük fajonként eltérö, hosszuk 16-41 $\mu \mathrm{m}$, szélességük 5-12 $\mu \mathrm{m}$ közötti (1. ábra) (Kusai és mtsi. 2016). 

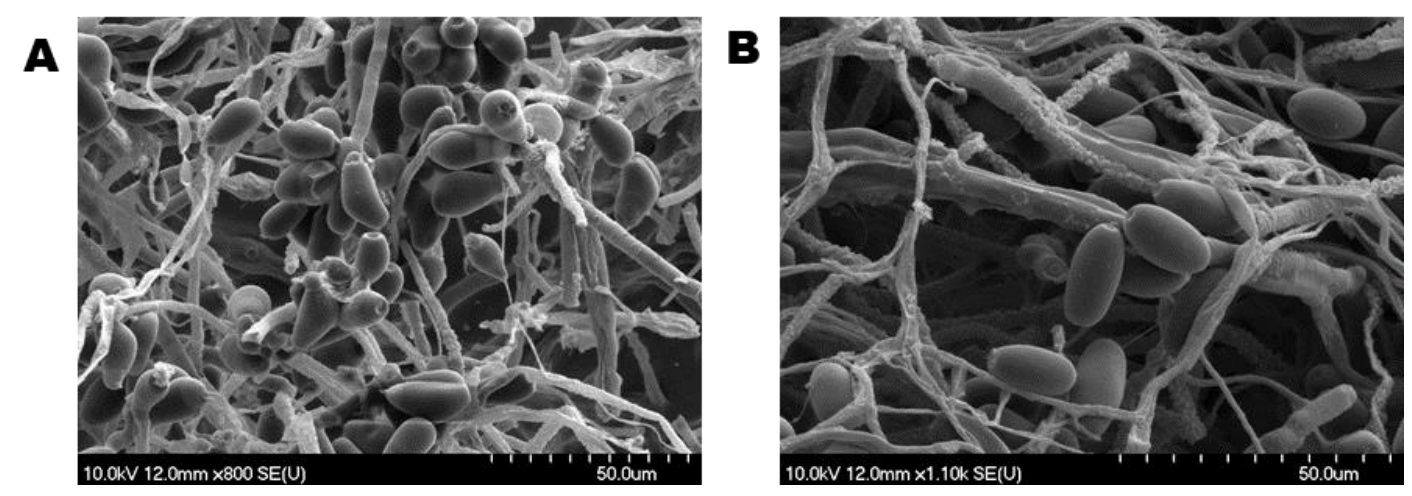

1. ábra: C. lunata (A) és C. hawaiiensis (B) konídiumok és hifák pásztázó elektronmikroszkópos felvétele.

A nemzetség tagjai alapvetően szaprotrófok, gyakran előfordulnak a talajban, növényi anyagokon vagy trágyában (Madrid és mtsi. 2014). Emellett fontos növénypatogének, melyek föképp a Poaceae család tagjait fertőzik, különösen a kukoricát, a búzát és a rizst, amivel gazdasági károkat okozhatnak. Egyes fajok opportunista humánpatogénként is számon tartottak (Manamgoda és mtsi. 2011), ezen fajok által okozott megbetegedések a felbukkanó gombafertőzések közé sorolhatók (Arif és Perfect 2017).

\subsection{A felbukkanó gombafertőzések jelentősége}

A felbukkanó gombafertőzések a nem Aspergillus fumigatus-hoz vagy Candida albicans-hoz köthető mikózisokat foglalják magukba (Pfaller és Diekema 2004). A fonalas gombák között a Mucorales rend képviselői, például a Lichtheimia, Rhizomucor és Mucor nemzetségek egyes tagjai, a Fusarium, a Scedosporium és a Trichoderma fajok, valamint a melanizált gombák csoportja, amelybe például a Cladophialophora, Alternaria vagy Curvularia fajok is tartoznak, felelősek a fertőzések kialakításáért (Arif és Perfect 2017).

$\mathrm{Az}$ ilyen jellegű fertőzések száma évről évre nő. Ennek hátterében az immunszuppresszált betegek számának növekedése állhat (Nagy és mtsi. 2004, Arif és Perfect 2017), de a fertőzések esélyét növeli a hosszantartó kórházi ápolás (Groll és Walsh 2001, Badiee és mtsi. 2011), vagy olyan civilizációs betegségek is, mint a cukorbetegség (Poradzka és mtsi. 2013). A molekuláris diagnosztika fejlődésének és elterjedésének köszönhetően pontosabb képet kaptunk ezen gombák előfordulásáról, valamint a klinikumban korábban nem diagnosztizált gombafertőzések is kimutathatóvá váltak. Mindez azonban nem feltétlenül jelenti azt, hogy eddig ezek a fajok nem voltak jelen tényleges 
patogénként (Roilides 2016). Mivel ezek a gombák gyakran elöfordulnak a környezetben, a növekvő esetszám mögött környezeti tényezők is állhatnak: a globális felmelegedés miatti klímaváltozás befolyásolhatja a gombák elterjedését, ezáltal a gombára nézve korábban nem jellemző területeken is leírnak fertőzéseket ( Raffa és mtsi. 2012, Debourgogne és mtsi. 2016). Ezzel összefüggésben az egyre gyakoribb természeti katasztrófák is kockázatot jelentenek a mikózisok megjelenésében (Benedict és Park 2014).

Ezeknél a fertőzéseknél a diagnózis felállítása nehézséget okoz, hiszen az általános képalkotó eljárások és vérvizsgálatok (például $\beta$-D-glükán teszt) alapján még nemzetség szinten sem határozható meg a fertőző ágens, valamint nem áll rendelkezésre a gyakoribb esetszámú gombákra már kifejlesztett egyszerü szerológiai vagy antigén teszt. Általában szükséges az izolátumok tenyésztése és mikroszkópos vizsgálata, valamint a molekuláris módszerekkel történő fajmeghatározás (Wong és Revankar 2016, Arif és Perfect 2017).

A kezelések egy részénél a műtéti beavatkozás jelenti a megoldást, amellyel a fertőzött szöveteket eltávolítják, emellett általánosan használnak gombaellenes szerekkel végzett kezelést is. Az ezek iránti érzékenység akár az egy nemzetséghez tartozó fajok között is nagyban eltérhet. Sok esetben hiányzik az egységes kezelési javaslat, főképp a kis esetszámú fertőzések esetében (Arif és Perfect 2017).

Ez különösen igaz a melanizált gombák csoportjára, amelyek a spórák belégzésével vagy perkután sérülés során kerülnek a szervezetbe. Ezen gombák patogenitási mechanizmusa nagyrészt ismeretlen. (Wong és Revankar 2016).

A melanizált gombák több mint 150 faja és 70 nemzetsége hozható összefüggésbe humán megbetegedésekkel (Revankar és Sutton 2010), amelyeket 3 fő csoportba oszthatunk (McGinnis 1983, Nagy és mtsi. 2004): (I) feohifomikózis, amikor melanizált gombahifa, élesztőszerủ sejtek vagy pszeudohifák találhatók a szövetekben és szklerotikus sejtek nélküli léziók jelentkeznek a fertőzött szövetben, (II) kromoblasztomikózis, mely krónikus, lokális kután vagy szubkután fertőzés, szemölcsszerü léziók és szklerotikus testek jellemzik, (III) eumikotikus micetóma, amely mélyszöveti fertőzéseket foglal magába, jellemzően micélium-aggregátumokat tartalmazó granulumokkal. 


\subsection{A Curvularia fajok által okozott fertőzések általános jellemzése és epidemiológiája}

A Curvularia fajok úgynevezett „curvulariózist” okoznak, amely a feohifomikózisok közé sorolható. Klinikai megjelenése függ a fertőzés helyétől és a beteg immunállapotától. A legtöbb opportunista patogénhez hasonlóan ezen fajok esetében is az opportunista jelleg a szisztémás mikózisok kialakítására vonatkozik, hiszen lokális fertőzést egészséges emberekben is okoznak. Felszíni fertőzéseket (keratitisz, kután, szubkután fertőzések) és allergiás megbetegedéseket okoznak leggyakrabban, de ezek mellett a tüdőt vagy a központi idegrendszert érintő és disszeminált fertőzéseket is leírtak (Revankar 2007). A Curvularia fertőzések földrajzi elterjedése a trópusi, szubtrópusi területeken a leggyakoribb, de kisebb esetszámban a mérsékelt övezetben is elöfordulnak.

\subsubsection{Felszíni fertőzések}

A Curvularia fajok által leggyakrabban okozott felszíni fertőzések a szemet érintik. A keratitiszes esetek legnagyobb része Indiából származik, de az Egyesült Államokban, Nepálban, Thaiföldön is írtak le ilyen fertőzéseket (Krizsán és mtsi. 2015). A bőrt érintő felszíni fertőzések előfordulnak például az Egyesült Államokban (Moody és mtsi. 2012), Japánban (Yanagihara és mtsi. 2010) vagy Ausztráliában (Torda és Jones 1997), amely utóbbi esetben nekrotizáló fertőzést figyeltek meg. A fertőzéseket általában sérülés előzi meg, amely utat nyit a gomba bejutásához.

\subsubsection{Légutakat érintő megbetegedések}

A légutakat érintő megbetegedések közül a Curvularia fajok leggyakrabban szinuszitiszt (orrmelléküreg-gyulladás) okoznak. Invazív (Viola és Sutton 2010) és neminvazív (Chapurin és mtsi. 2016, Cavanna és mtsi. 2014) formára is találunk példát az esetleírások között. Az invazív fertőzés kialakulása nem függ immunszuppressziótól. A neminvazív szinuszitisz leggyakoribb megjelenési formája Curvularia fajok esetében az allergiás gombás rinoszinuszitisz, amelyek közül a legtöbb esetet az Egyesült Államokban diagnosztizálták (Krizsán és mtsi. 2015), de például Katarból (Taj-Aldeen és mtsi. 2004), Franciaországból (Ambrosetti és mtsi. 2006), Olaszországból (Posteraro és mtsi. 2010) és Indiából (Chowdhary és mtsi. 2011) is származnak esetleírások. 
Az allergia kialakításában fontos szerepe van a gomba által termelt allergén molekuláknak. Ezen molekulák kutatása nem csak az allergiás folyamatok megértése szempontjából lehet fontos, hanem immunterápiás kezelésekben is felhasználhatóak lehetnek. C. lunata esetében fö allergénekként azonosították a Cur 11 (szerin proteáz), Cur 1 2 (enoláz) és Cur 13 (citokróm-c) fehérjéket. A Cur 13 fehérjével és annak epitóp peptideivel egér modellben sikeres immunterápiát is végeztek (Sharma és mtsi. 2011).

A tüdőt érintő elsődleges fertőzések között leggyakrabban allergiás bronchopulmonáris mikózishoz kapcsolhatók ezek a fajok. A szinuszitiszhez hasonlóan a fertőzés ezen megjelenési formája is az Egyesült Államokban és Ausztráliában gyakoribb (Chowdhary és mtsi. 2014, Landaeta és mtsi. 2017, Noda Milla és mtsi. 2015).

\subsubsection{Központi idegrendszeri megbetegedések}

A Curvularia fajok központi idegrendszeri fertőzést is okozhatnak, mely leggyakrabban másodlagos fertőzésként alakul ki, például krónikus szinuszitiszböl (Viola és Sutton 2010, Gadgil és mtsi. 2013). Ezt a fertőzési formát is leírták már immunkompetens egyéneknél is (Carter és Boudreaux 2004). Az esetleírások az Egyesült Államokból származnak.

\subsubsection{Disszeminált és invazív fertőzések}

A disszeminált fertőzések kialakulása során, mint ahogy egyéb gombás fertőzéseknél is, kockázati tényezőt jelent az immunszuppresszált állapot, vagy bármilyen, a szervezet védelmi vonalait érintő elégtelenség. A szakirodalomban találunk példát immunszuppresszált betegben kután fertőzésből kialakult disszeminált fertőzésre (Balla és mtsi. 2016), de a vérképzőszervi rendellenesség (Chang és mtsi. 2018) vagy a kiterjedt égési sérülés (Beckett és mtsi. 2017) is növeli a fertőzés esélyét. Immunkompetens egyénben is volt példa disszeminált fertőzésre, amely a vesét és agyat érintette (Frank s mtsi. 2016). A fent említett esetleírásokból az látható, hogy ezek a fertőzések leggyakrabban az Egyesült Államokban fordultak elő, de problémát okoztak Ausztráliában és Japánban is. 


\subsection{A Curvularia fajok patogenitása}

A Curvularia fajok növényekkel kapcsolatos patogenitásával számos kutatás foglalkozott (Gao és mtsi. 2013, Gao és mtsi. 2014, Liu és mtsi. 2016, Gao és Chen 2017b), azonban az emberi megbetegedések vonatkozásában inkább csak esetleírások állnak a rendelkezésünkre és a patogenitási folyamatról keveset tudunk.

Emlős modellen végzett korai vizsgálatok főleg annak bizonyítására szolgáltak, hogy a fajok képesek a fertőzésre (Whitcomb és mtsi. 1981, Alture-Werber és Edberg 1985). Egy későbbi tanulmány is beszámolt arról, hogy a humán szervezetből izolált törzsekkel fertőzött egészséges és immunszuppresszált állatok szerveiben a gomba kimutatható (Vishnoi és mtsi. 2005). Egér modellben végzett vizsgálatok azt mutatták, hogy az immunszuppresszált állatok fertőzése magas mortalitást eredményezett, továbbá a gomba elsődlegesen a tüdőt és a vesét kolonizálta (Paredes és mtsi. 2013). Azonban magáról a fertőzési folyamatról vagy a virulenciafaktorokról nem áll rendelkezésünkre információ.

Mivel egészséges emberekben a Curvularia törzsek leggyakrabban allergiás megbetegedésekkel hozhatók összefüggésbe, az allergének meghatározására is irányultak kutatások, amelyek során azonosították például a korábban már említett Cur 1 fehérjéket (Gupta és mtsi. 2004, Sharma és mtsi. 2011) és az alkohol dehidrogenázt is (Nair és mtsi. 2011).

\subsection{A Curvularia lunata lehetséges virulencia faktorai}

A humán fertőzésekhez köthető virulenciafaktorokról nincs adatunk, azonban a gombafaj számos, a növények fertőzésében szerepet játszó virulenciafaktorát azonosították. Ide tartozik például a nem gazda specifikus furanoid toxin (Liu és mtsi. 2009) és a melanin bioszintézise (Xu és mtsi. 2007), amely szintetikus útvonalakban a brnl gén által kódolt enzim szerepet játszik (Liu és mtsi. 2011). Virulenciafaktorként azonosították például a $\operatorname{clm} 1$ (Wang és Chen 2011) és clkl (Gao és mtsi. 2013) gének által kódolt mitogén aktivált protein kinázokat (MAPK), a ClPKS18 poliketid szintázt (Gao és Chen 2017a) vagy a ClVelB velvet fehérjét (Gao és mtsi. 2017). 


\subsubsection{A melanin szerepe a patogenezisben}

A melaninok a pigmentek egy diverz csoportját alkotják, amelyek fenolos vegyületek hidroxilációjával és polimerizációjával jönnek létre. Szintézisük alapján három fő csoportot különböztetünk meg: i) a fekete vagy barna eumelaninok, amelyek szintézise során a tirozin ciklizációjával o-dihidroxifenilalanin (DOPA) és dopakinon keletkezik és ezek további ciklizációs lépéseken mennek keresztül, ii) a pirosas színű feomelaninok, amelyek szintézise az eumelaninokéhoz hasonló, azonban a DOPA ebben az esetben ciszteinizálódik, valamint iii) az allomelaninok, amelyek di- vagy tetrahidroxinaftalén molekulák oxidációjával és polimerizációjával keletkeznek a pentaketid útvonalon (2. ábra) változatos színű polimereket hozva létre (Plonka és Grabacka 2006).

A $C$. lunata dihidroxinaftalén (DHN) melanint szintetizál, amely a konídiumokban és a hifákban is megtalálható (Lanisnik és Wheeler 2003), míg az A. fumigatus DHN-melanin és az ugyancsak az allomelaninok közé sorolható piomelanin szintézisére képes, amely csak a konídiumok falában halmozódik fel (Heinekamp és mtsi. 2012). A DHN-melanin bioszintetikus útvonala kémiailag gátolható például triciklazollal vagy Pyroquilon-nal (Wheeler és Klich 1995). A ticiklazol kis koncentrációban $(1 \mu \mathrm{g} / \mathrm{ml})$ gátolja az 1,3,8-tri-HN vermelonná történő átalakítását, magasabb koncentrációban $(10 \mu \mathrm{g} / \mathrm{ml})$ az 1,3,6,8-tetra-HN redukcióját is (Tokousbalides és Sisler 1979).

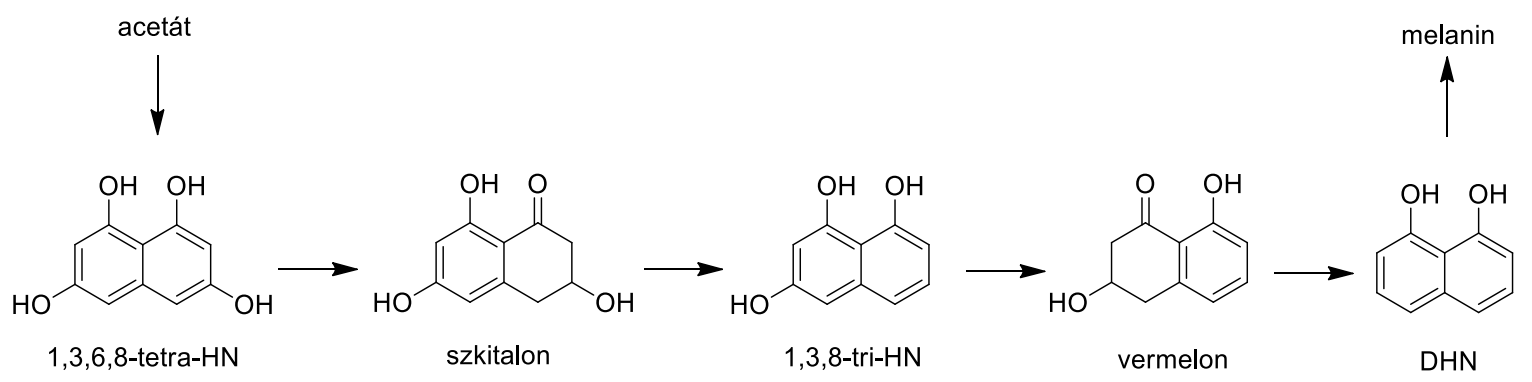

2. ábra: A C. lunata és az A. fumigatus által is termelt DHN-melanin szintézisének útvonala. HN: hidroxinaftalén; DHN: dihidroxinaftalén

A mikroorganizmusok esetében a melaninok számos funkciót elláthatnak. Környezeti hatásokkal szemben hatékony védelmet nyújthatnak: a melanizált Sporothrix schenckii konídiumai az UV besugárzással szemben ellenállóbbak, mint a nem melanizált konídiumok (Romero-Martinez és mtsi. 2000). 
A pigmentek virulenciafaktorként betöltött szerepét több organizmusnál is vizsgálták. Wang és munkatársai (1995) kísérleteiben a Cryptococcus neoformans esetében a melanin hiánya virulencia csökkenést eredményezett, a melanizált törzsek ellenállóbbak voltak az oxigén és nitrogén gyökökkel szemben, valamint a pigment a fagocitózis gátlásában is szerepet játszott. A melanin antioxidáns kapacitását egyéb melanizált gombák, pl. Exophiala dermatitidis és Alternaria alternata, esetében is bizonyították (Jacobson és mtsi. 1995). A melanin hidrogén-peroxid $\left(\mathrm{H}_{2} \mathrm{O}_{2}\right)$ és hipoklórossav $(\mathrm{HOCl})$ semlegesítő hatását például $A$. nidulans esetében is igazolták (de Cassia és Pombeiro-Sponchiado 2005). Az E. dermatitidis által termelt melanin a neutrofil granulociták fagocitózisát vagy oxidatív folyamatait nem befolyásolta, azonban szerepet játszott a fagolizoszómán belüli túlélésben (Schnitzler és mtsi. 1999). C. neoformans és Histoplasma capsulatum esetében a melanin csökkentette az amfotericin B-vel és kaszpofunginnal szembeni érzékenységet (van Duin és mtsi. 2002). A melanin azonban nem csak a túlélést segítheti, hanem a felismerés célpontja is lehet. Az $A$. fumigatus spórafalában található melanint a mieloid sejtek MelLec receptora képes felismerni, amely szerepet játszik a gombaellenes folyamatok indukciójában (Stappers és mtsi. 2018).

\subsubsection{A haloperoxidáz enzimek jellemzése és szerepe}

A peroxidáz enzimek majdnem minden élölényben megtalálhatók, oxidatív reakciókat katalizálnak, amelyekhez elektron akceptorként különböző peroxidokat használnak fel. Lehetnek hem és nem-hem fehérjék A főbb csoportokat a 3. ábra szemlélteti. A hem peroxidázok többsége két nagyobb családba sorolható, az egyikbe föleg növényekben, baktériumokban és gombákban előforduló enzimek tartoznak, a másikban főleg állati peroxidázok találhatók. Ezen kívül 4 kisebb családot is elkülönítenek, ezek a katalázok, a dihem citokróm C peroxidázok, a Dyp-típusú peroxidázok és a hem-haloperoxidázok. A nemhem peroxidázok öt független családba sorolhatók, melyek közül az egyik a haloperoxidázok csoportja (Koua és mtsi. 2009). 


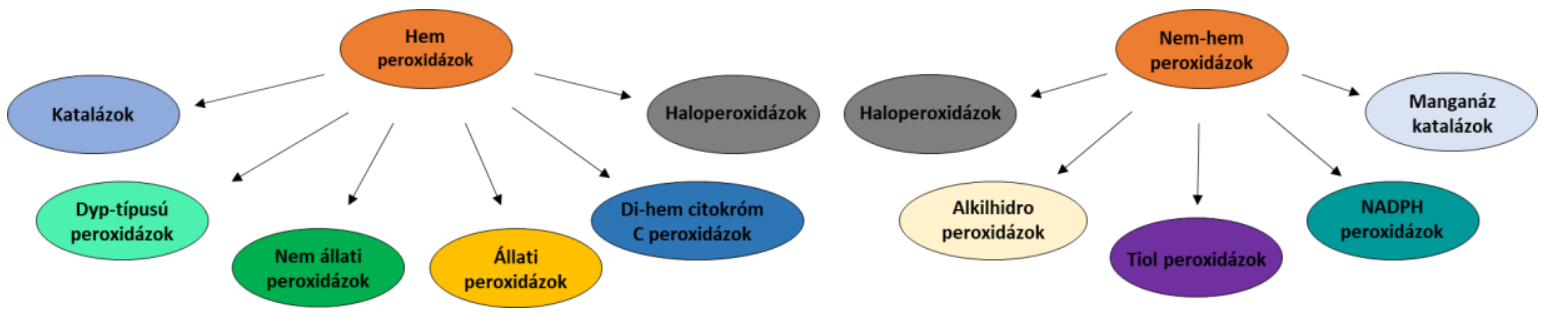

3. ábra: A peroxidázok föbb csoportjai (Koua et al. 2009).

A haloperoxidázok halidok oxidációját végzik hidrogén peroxid felhasználásával (Butler 1998). Az enzimek tartalmazhatnak fémiont az aktív centrumban, amely lehet hemcsoport vagy vanádium, de fémion nélküli aktív centrummal is rendelkezhetnek. A három csoport kismértékủ szekvencia-homológiát mutat (Conesa és mtsi. 2002).

A vanádium haloperoxidázok egy vanadát iont tartalmaznak a fémion centrumban és az általuk oxidált legelektronegatívabb ion alapján csoportosíthatók. A kloroperoxidázok (CPO) klorid, bromid és jodid ionokat is képesek felhasználni, míg a bromoperoxidázok csak bromid és jodid ionokat (Winter és Moore 2009). Gombák esetében a vanádium kloroperoxidázoknak a növényi sejtfal bontásában tulajdonítanak szerepet. Az enzimek lignocellulóz oxidációjával elősegítik a gomba növényi sejtbe történő bejutását, ezáltal virulenciafaktorként számontartottak (Butler és mtsi. 2001, Wever és Hemrika 2001).

A C. lunata-val közeli rokon C. inaequalis nem-hem kloroperoxidázát (CPO) 1987ben írták le először (Liu és mtsi. 1987), majd van Schijndel és munkatársai (1993) vanádium kloroperoxidázként azonosították. Az enzim monomer szerkezetü, a központi egység két 4 darab $\alpha$-hélixből álló kötegbe rendeződik a harmadlagos szerkezetben (Messerschmidt és Wever 1996). A vanadát-ion a His ${ }^{496}$ aminosav nitrogén atomjához, valamint négy nem fehérje eredetű oxigén atomhoz kötődik trigonális bipiramis szerkezetben (Messerschmidt és mtsi. 1997), a negatív töltést az $\operatorname{Arg}^{360}$ aminosav kompenzálja (Macedo-Ribeiro és mtsi. 1999). A kötőhelyet a 4. ábra illusztrálja. 


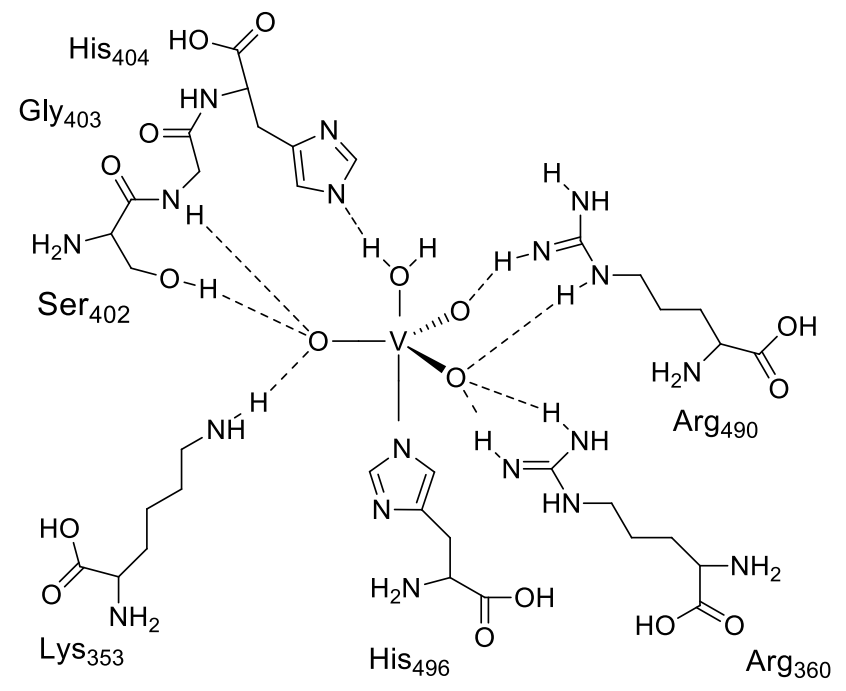

4. ábra: A C. inaequalis kloroperoxidáz vanádium kötőhelye. (Winter and Moore 2009)

A katalitikus aktivitásért a His ${ }^{404}$ aminosav felelős. A halid kötését valószínüleg a Phe ${ }^{397}$ és Trp ${ }^{350}$ végzik (Hasan és mtsi. 2006). Ezen haloperoxidáz esetében a kataláz aktivitás nem volt kimutatható (Fernández-Fueyo és mtsi. 2015), ami általánosan elmondható a vanádium kloroperoxidázokról (Renirie és mtsi. 2009).

A gomba hem peroxidázok egy protopofririn IX (hem $b$ ) kofaktort tartalmaznak. A hem csoport egy N-terminális és C-terminális helix között helyezkedik el (Conesa és mtsi. 2002). Ezek a haloperoxidázok általában rendelkeznek kataláz aktivitással (Renirie és mtsi. 2009, Sun és mtsi. 1994).

A fémion mentes haloperoxidázok szerkezetét például Pseudomonas fluorescens, Streptomyces aureofaciens és Streptomyces lividans esetében vizsgálták. A S. aureofaciens kloroperoxidáza az észteráz/lipáz enzimek nagyobb csoportjába tartozik (Hecht és mtsi. 1994). A P. fluorescens és $S$. lividans kloroperoxidázok specifikus halid kötőhelye valószínüleg hiányzik (Hofmann és mtsi. 1998).

A gomba haloperoxidázok virulenciában betöltött szerepét humán patogének esetében még nem vizsgálták, viszont mivel az enzimek maguk is szerepet játszanak reaktív oxigéngyökök termelésében, jelenlétük a gombában feltételezi a ROS-okkal szembeni hatékony védelmi mechanizmus meglétét. Néhány haloperoxidáz kataláz aktivitással is rendelkezik, a $\mathrm{H}_{2} \mathrm{O}_{2}$ semlegesítésében is szerepet játszhatnak. 


\subsection{Az A. fumigatus általános jellemzése és az általa okozott megbetegedések}

Az A. fumigatus az Aspergillus nemzetség Fumigati szekciójába tartozó szaprotróf fonalas gomba, amelynek természetes élőhelye a talaj. Bőségesen spórázik, spórái 2-3 $\mu \mathrm{m}$ átmérőjüek, szinte mindenhol megtalálhatók a levegőben (Mullins és mtsi. 1976), ezért leggyakrabban belégzés útján jutnak be az emberi szervezetbe. Kis méretüknek köszönhetően könnyen elérik az alveolusokat. A belélegzett konídiumokat immunkompetens egyénekben hatékonyan eliminálják az immunsejtek, azonban immunszuppresszált vagy immundefficiens betegekben akár halálos kimenetelü invazív fertőzések kialakítására is képesek (Latge 1999).

A tüdőt érintő megbetegedések közül kolonizáció nélkül asztma, allergiás szinuszitisz alakulhat ki, amely a spórákkal szembeni erőteljes kitettséggel hozható összefüggésbe. Ha a gomba micéliuma is jelen van a légzőszervrendszerben, allergiás bronchopulmonáris aszpergillózis, aszpergillóma vagy invazív aszpergillózis alakulhat ki. Ezen kívül az A. fumigatus egyéb testtájakon is okozhat fertőzést, pl. a börön, a hasüregben, a vesékben, vagy a szemben (Latge 1999).

\subsection{A gombák elleni természetes immunválasz - effektor sejtek}

A természetes immunválasz az immunrendszer elsődleges védelmi vonala. Ennek kialakításában rész vesznek fizikai gátak, mint a bőr vagy nyálkahártya, amelyek megakadályozzák a mikroorganizmusok bejutását a szervezetbe, a komplement rendszer elemei, amelyek segítik az immunsejtek általi felismerést, valamint maguk az effektor sejtek, amelyek egymással is együttmüködve képesek a mikroorganizmusok eliminálására, valamint az adaptív immunválasz aktiválására (Ghuman és Voelz 2017). A természetes immunválasz sejtjei közé tartoznak a monociták, makrofágok, neutrofil granulociták, dendritikus sejtek, hízósejtek, bazofil és eozinofil granulociták valamint az epitél sejtek (5 ábra). Ezek közül hivatásos antigénprezentáló sejtek a makrofágok és a dendritikus sejtek, azonban mindegyik sejttípus képes antigén bemutatására, amellyel a $\mathrm{T}$ sejtek differenciációját indukálják (Murphy és mtsi. 2008). 


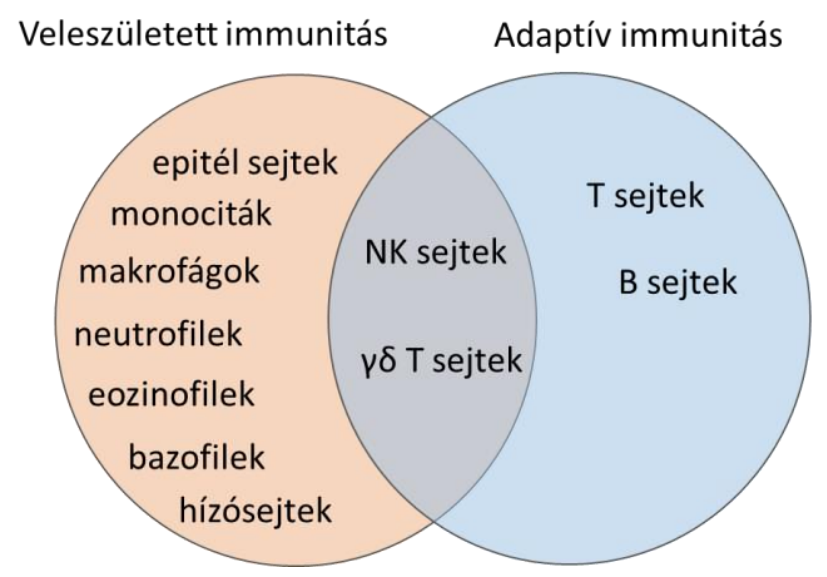

5. ábra: A veleszületett és az adaptív immunitás sejtjei.

A fonalas gombák elleni immunválasz modellezésére leggyakrabban az A. fumigatust használják (Park és Mehrad 2009, Heinekamp és mtsi. 2015), azonban a felbukkanó fertőzéseket okozó fajok közül is egyre többet bevonnak a kutatásokba. Ezen fajok között a Mucorales rend képviselői (Ghuman és Voelz 2017) és a Scedosporium fajok (Roilides és mtsi. 2009, Kaur és mtsi. 2019) által kiváltott immunválaszról áll rendelkezésre nagyobb mennyiségü információ.

Mivel a dolgozat a monociták, makrofágok és neutrofil granulociták C. lunata-ra adott válaszát vizsgálja, a továbbiakban ez a három sejttípus kerül bemutatásra.

\subsubsection{Monociták}

A monociták a vérben található, csontvelői eredetủ leukociták, amelyek a mieloid útvonalon jönnek létre. Funkcionálisan a fagocitózisra való képesség, antigénprezentáció és citokintermelés jellemzi őket (Ziegler-Heitbrock 2015). A monociták szubpopulációit CD14 és CD16 markerek alapján különítjük el. A klasszikus monocita sejtek a CD14 molekulát erősen expresszálják, a nem klasszikus monocitákra viszont a CD16 marker erősebb kifejezése jellemző. A két molekulát egyenlő mennyiségben expresszáló sejteket a köztes fenotípusú alpopulációba sorolják (Ziegler-Heitbrock és mtsi. 2010). Egérben a klasszikus és nem-klasszikus populációk ugyanúgy megtalálhatók, amelyek a CD115, CD45 és Ly6C markerek alapján különíthetők el (Ingersoll és mtsi. 2010).

Fagocitózis után a monociták az antigéneket MHC molekulán keresztül mutatják be. Az antigének prezentációjával és azok nyirokszervekbe történő szállításával szabályozzák az adaptív immunrendszert. A T sejtek differenciációjának szabályozásával helper, citotoxikus, 
de akár regulátor T sejtek proliferációját is elősegíthetik (Augier és mtsi. 2010, Jakubzick és mtsi. 2017).

A monociták aktivációját mikrobiális, gyulladásos vagy egyéb patológiás szignálok indukálhatják (Ivanova és Orekhov 2016). A mikrobiális szignálok közé tartoznak többek között a gomba PAMP-ok (patogén-asszociált molekuláris mintázat) is, amelyek felismerésében elsősorban a Toll-like receptorok (TLR) vagy C-típusú lektin receptorok (CLR) játszanak szerepet (Lauvau és mtsi. 2015). Az aktivációs szignál elindítja a monociták differenciációját, amely során a sejtek a szövetek közé vándorolnak (Shi és Pamer 2011). A CD14 ${ }^{+}$monociták az érfalon való átlépés után többféle útvonalon fejlödhetnek: differenciálódhatnak makrofágokká vagy dendritikus sejtekké (Plantinga és mtsi. 2013, Tamoutounour és mtsi. 2013, Jakubzick és mtsi. 2017) (6. ábra), de akár fenntarthatják a monocita állapotot is (Jakubzick és mtsi. 2013, Jakubzick és mtsi. 2017).

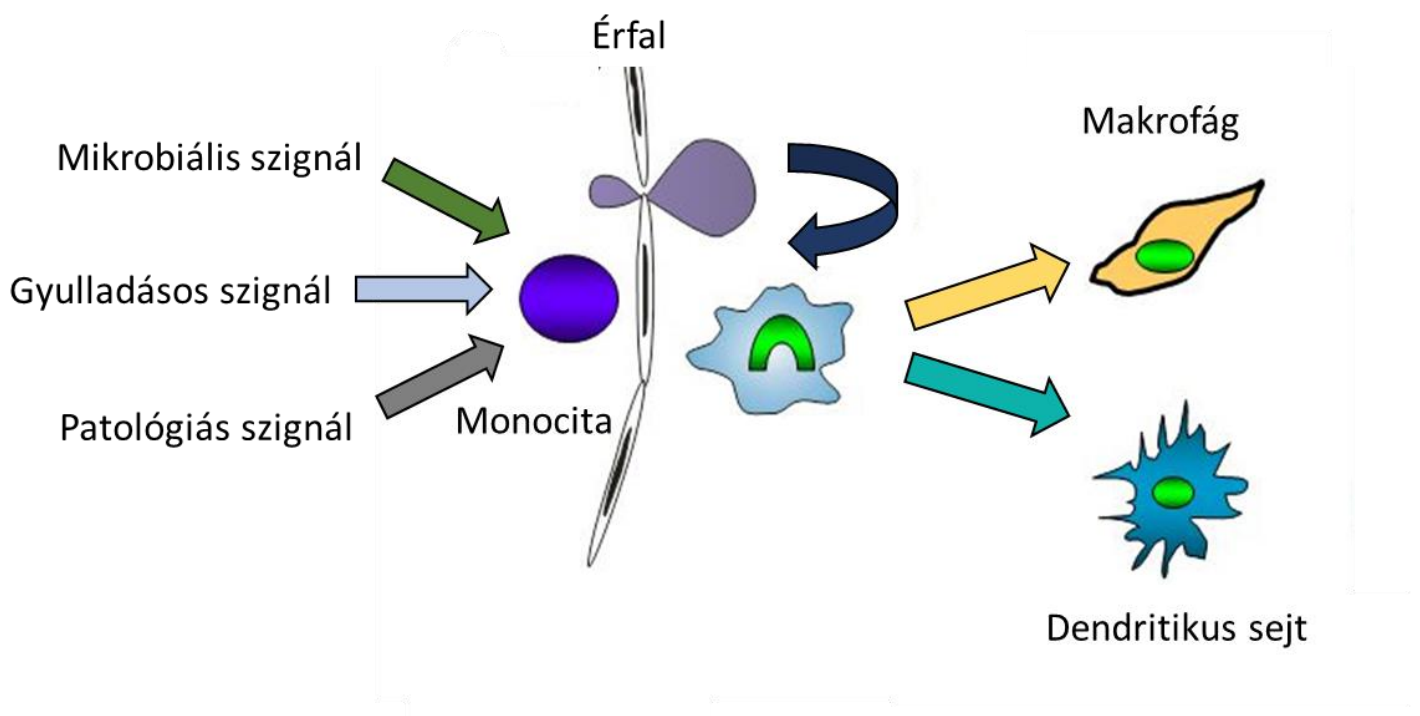

6. ábra: A monociták aktivációjának és differenciációjának folyamata. A monociták a szignálok hatására az érfalon keresztül a szövetek közötti térbe lépnek, majd ott differenciálódnak (https://slideplayer.hu/slide/2108693/).

A monociták differenciációja során többek között az endotél sejtekkel való kapcsolat kialakításához szükséges fehérjék jelennek meg a sejtek felszínén. Ilyen fehérjék az integrinek, amelyek a sejt-sejt kapcsolatok kialakításán (Hynes 1987) kívül a fagocitózissal összefüggő jelátvitelben is szerepet játszanak (Aplin és mtsi. 1998). A primer monociták makrofággá történő differenciálódása során a CD11a, CD11b és CD11c molekulák expressziója emelkedik meg, míg dendritikus sejtté való differenciálódásnál a CD11b és 
CD11c expressziója nő meg. A dendritikus sejteken a CD11a expressziója is megmarad (Ammon és mtsi. 2000).

A monociták a kemokin receptorok közül elsősorban a CCR1, CCR2 és CCR5 molekulákat expresszálják, amelyek az infiltrációt kiváltó kemokinek kötéséért felelősek (Yang és mtsi. 2014). Az érés során a CCR2 molekula mennyisége csökken, amely transzkripciós szinten is kimutatható (Phillips és mtsi. 2005).

\subsubsection{A monociták szerepe a patogén fonalas gombák elleni védekezésben}

A monociták A. fumigatus-ra adott válasza függ attól, hogy a gomba milyen formában van jelen a szervezetben. A konídiumok jelenléte ugyan vált ki fagocitózist, de a citokin és kemokin kódoló gének expresszióját nem indukálja. Ezzel szemben a csíratömlö megjelenése, valamint a hifák jelenléte ezen gének expresszióját váltja ki (Loeffler és mtsi. 2009).

Az A. fumigatus okozta légúti megbetegedések esetén a monociták által közvetített védekező mechanizmusok elengedhetetlenek a gomba eliminálásában. A monociták és a monocita eredetü dendritikus sejtek fokozzák a neutrofilek ölési képességét a konídiumokkal szemben (Espinosa és mtsi. 2014), valamint a T sejtes válasz szabályozásában is részt vesznek (Rivera és mtsi. 2011). A monociták fagocitózis után NADPH-oxidáz dependens útvonalon közvetlenül is képesek a belélegzett Aspergillus konídiumok ölésére (Jhingran és mtsi. 2012, Espinosa és mtsi. 2014). A CD14+ sejtek gátolják a gombasejtek növekedését, míg a CD16+ sejtek inkább a citokintermelésben (TNF- $\alpha$, IL1) játszanak szerepet, azonban a citokin szekréció csak élő konídiumok jelenlétében valósul meg (Serbina és mtsi. 2009).

\subsubsection{Makrofágok}

A makrofágok a szövetekben található mieloid eredetű immunsejtek, amelyek az idegen anyagok, elpusztult sejtek eltakarítását, valamint gyulladásos szignál jelenlétében egyéb immunsejtek toborzását végzik. A professzionális fagociták közé sorolhatók, a patogének jelenlétét TLR, NOD-like és C-típusú lektin receptorokon keresztuil érzékelik (Akira és mtsi. 2006, Murray és Wynn 2011). Szöveti elhelyezkedésük szerint csoportosíthatjuk őket, funkciójukat a szöveti környezet is befolyásolja. Például a bélfalban található makrofágok a dendritikus sejtekkel együttmüködve alakítják ki a bélflórával szembeni toleranciát, a lép marginális zónájának makrofágjai az immunsejtek 
szuppresszióját végzik az apoptotikus sejtekkel szemben (McGaha és mtsi. 2011, Murray és Wynn 2011). A szöveti makrofágok egy része, föleg gyulladásos körülmények között, a monociták differenciációjával jön létre (Gordon és Taylor 2005), azonban egyéb populációk, mint a Kupffer-sejtek vagy az alveoláris makrofágok már magzati korban a szövetek közé vándorolnak és helyben proliferálódnak (Yona és mtsi. 2013)

A szöveti makrofágok a klasszikus (M1) és alternatív (M2) útvonalon aktiválódhatnak. Az M1 makrofágok proinflammatorikus funkciójú sejtek, amelyek a Th1-es választ, míg az antiinflammatorikus M2 sejtek a Th2-es választ indukálják. Az M1 fenotípus kialakulását többek közt a TLR ligandok általi aktiváció eredményezheti. Ilyen ligand pl. a Gram-negatív baktériumok külső membránjában található lipopoliszacharid (LPS), amely a TLR4-hez kötődik (Nau és mtsi. 2002). Az M2 fenotípus további csoportokra bontható. Az M2a típusú sejtek a Th2 sejtek által aktivált makrofágok, amelyek kialakulása a Th2 sejtekböl felszabaduló IL4 és IL13 citokinektől függő folyamat (Martinez és mtsi. 2013). Az M2b csoportba tartozó sejtek immunkomplex (antigén és ellenanyag kölcsönhatása) és TLR ligand kombinált szignál jelenlétében figyelhetők meg. Az M2c, vagy immunregulátor sejtek kialakulását az IL10 jelenléte váltja ki (Park-Min és mtsi. 2005, Martinez és Gordon 2014).

\subsubsection{A makrofágok szerepe a patogén fonalas gombák elleni védekezésben}

A makrofágok a fonalas gombák spóráit, konídiumait fagocitálják, majd intracelluláris mechanizmusokkal károsítják, azonban ezen antifungális mechanizmusok az egyes fajokkal szemben eltérö lehet. A Rhizopus fajok fagocitált spóráinak csírázását a sejtek vaséheztetés útján gátolják, ugyanis a fertőzés során a vas sejten belüli transzportjához és eloszlásához köthető gének transzkripciós változását figyelték meg (Andrianaki és mtsi. 2018), az A. fumigatus konídiumok ölése viszont fagolizoszóma savasodásával és intracelluláris oxidatív útvonalon történik (Ibrahim-Granet és mtsi. 2003, Philippe és mtsi. 2003).

$\mathrm{Az}$ A. fumigatus spórák leggyakrabban belégzéssel kerülnek a szervezetbe, ezért a spórák eliminálásában az alveoláris makrofágoknak elengedhetetlen szerepe van. A nyugvó konídiumokat a sejtek fagocitálják, azonban citokinek és reaktív oxigénfajták (ROS) szekrécióját ez a forma nem váltja ki (Gersuk és mtsi. 2006), az intracelluláris ölési mechanizmusok aktivációja a duzzadt konídiumok megjelenésekor történik meg (Philippe és mtsi. 2003). A fagocitózis indukciójában a Dectin-1 és a TLR2 receptorok játszanak szerepet 
(Luther és mtsi. 2007). Érdekes módon a konídiumok a makrofágok alternatív útvonalú polarizációját indukálják (Bhatia és mtsi. 2011). A makrofágok gátolják a neutrofil funkciókat a konídiumok jelenlétében (Rosowski és mtsi. 2018). A nem fagocitált duzzadt és csírázó konídiumok már indukálják a citokinek és a ROS szekrécióját (Gersuk és mtsi. 2006), azonban a sejttípus elsődleges feladata a konídiumok eliminálása (Schaffner és mtsi. 1982).

\subsubsection{Neutrofil granulociták}

A neutrofil granulociták csontvelöi eredetü sejtek, amelyek folyamatosan termelödnek a mieloid prekurzor sejtekből (Borregaard 2010). Emberben a keringő leukociták 50-70\%-át teszik ki (Mestas és Hughes 2004). 7-10 $\mu$ m átmérőjü, szegmentált sejtmagú sejtek, amelyek citoplazmájában számos granulum és szekretoros vezikula található (Borregaard 2010). A granulumok három csoportba oszthatók: i) azurofil (elsődleges) granulum, amely mieloperoxidáz enzimet (MPO), specifikus proteázokat és defenzineket tartalmaz; ii) specifikus (másodlagos) granulum, amelyben többek között laktoferrin és zselatináz található; iii) zselatináz (harmadlagos) granulum, amely a mátrix metalloproteináz 9 enzimet tartalmazza (Faurschou és mtsi. 2002, Borregaard 2010, Hager és mtsi. 2010).

A neutrofilek a patogéneket intra- és extracelluláris útvonalakon is képesek eliminálni. Azt, hogy melyik útvonal aktiválódik a patogén mérete is befolyásolja: a kis méret fagocitózist és intracelluláris ölést, a nagy méret extracelluláris ölési mechanizmusokat indukál (Warnatsch és mtsi. 2017). A patogén bekebelezése után a neutrofil sejtek NADPHoxidáz függő ROS termeléssel és a granulumokból az antimikrobiális peptidek fagoszómába ürítésével károsítják a mikroorganizmust (Borregaard 2010, Hager és mtsi. 2010). Az extracelluláris ölési mechanizmusban is szerepet játszik a ROS és a granulumokból felszabaduló enzimek általi károsítás (degranuláció), valamint az extracelluláris csapda (NET - neutrophil extracellular trap) formálás is (Brinkmann és mtsi. 2004, Papayannopoulos és Zychlinsky 2009) (7. ábra). 


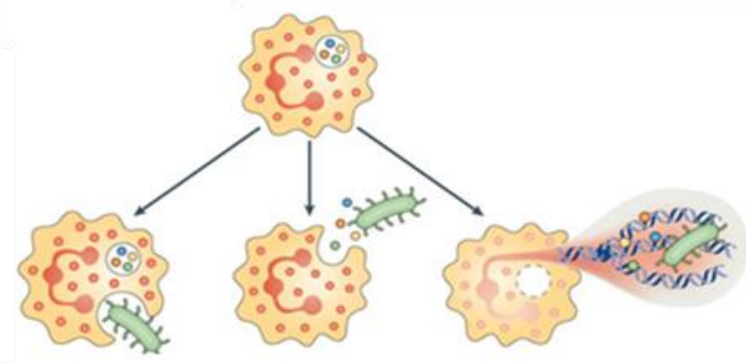

Fagocitózis Degranuláció NET

7. ábra: A neutrofil granulociták effektor funkciói: fagocitózis, degranuláció és NET formálás (Kolaczkowska és Kubes 2013).

A NADPH-oxidáz függő ROS termelés, az oxidatív burst folyamatában a membránkötött NADPH-oxidáz elektront vesz fel a citoplazmatikus NADPH-tól, amelyet molekuláris oxigénhez köt szuperoxid gyököt $\left(\mathrm{O}_{2}{ }^{-}\right)$hozva létre, amely gyors reakcióban spontán vagy szuperoxid dizmutáz (SOD) által $\mathrm{H}_{2} \mathrm{O}_{2}$-dá alakul (Babior és mtsi. 2002, Bedard és Krause 2007). Ezután a MPO HOCl-t hoz létre a $\mathrm{H}_{2} \mathrm{O}_{2}$ felhasználásával (Klebanoff 1999, Klebanoff 2005). Emellett a MPO a $\mathrm{O}_{2}^{-}$közvetlen felhasználásával szinglet oxigén $\left(\Delta^{1} \mathrm{O}_{2}\right)$ előállítására is képes (8. ábra) A $\mathrm{HOCl}$ ezután képes reakcióba lépni a $\mathrm{H}_{2} \mathrm{O}_{2}$-dal és szinglet oxigént vagy peroxil gyököket létrehozni (Miyamoto és mtsi. 2006).

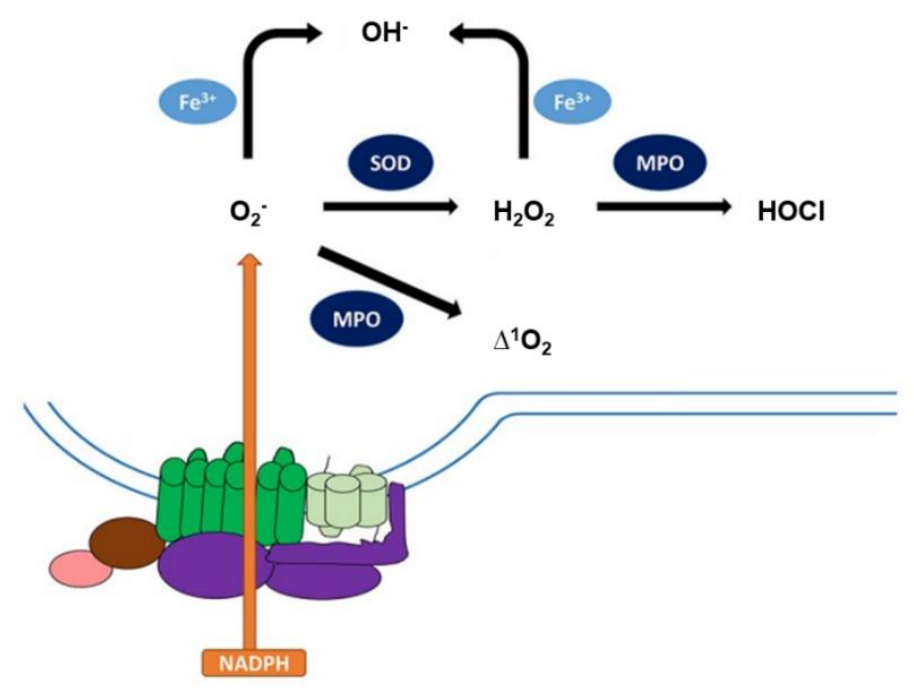

8. ábra: Az oxidatív burst folyamata. (Nguyen, Green and Mecsas 2017). $\Delta^{1} \mathrm{O}_{2}$ : szinglet oxigén; $\mathrm{H}_{2} \mathrm{O}_{2}$ : hidrogén peroxid; MPO: mieloperoxidáz; NADPH: Nikotinamid-adenin-dinukleotid-foszfát; $\mathrm{O}_{2}$ : szuperoxid gyök; $\mathrm{OH}^{-}$: hidroxil gyök; SOD: szuperoxid dizmutáz; 
A NADPH-oxidáz komplexre számos receptoron keresztüli jelátvitel hathat. Ezek közül a legtöbb G-protein kapcsolt receptorról (GPCR), a TLR-ekről és a citokin receptorokról érkező szignál elsődleges impulzusként szolgál a sejteknek, felkészíti a második szignálra adott erőteljes válaszra. Ezek a jelátviteli folyamatok nem indukálnak $\mathrm{O}_{2}^{-}$ termelést, azonban az enzimkomplex egy-egy tagjának foszforilációját, transzlokációját szabályozhatják Az Fc receptorok (opszoninokat kötő receptorok) és integrin receptorok (mint pl. a CR3) jelátviteli folyamatai azonban közvetlenül képesek aktiválni a NADPHoxidázt, így $\mathrm{O}_{2}{ }^{-}$termelést váltanak ki (Nguyen és mtsi. 2017).

A MPO érett formában tárolódik a neutrofilek azurofil granulumaiban. A sejtek receptorokon keresztüli aktivációja után az enzim sejtböl való kijutása történhet degranulációval, apoptózis/nekrózis következtében (Bentwood és Henson 1980, van der Veen és mtsi. 2009, Odobasic és mtsi. 2013) vagy a NET képzés velejárójaként (Kessenbrock és mtsi. 2009). A már tárgyalt enzimatikus aktivitáson kívül az MPO nem-enzimatikus szabályozó szerepet is betölt. Proinflammatorikus hatása, hogy autokrin módon aktiválhatja a neutrofil granulocitákat (Lau és mtsi. 2005), azonban egyéb leukociták toborzását is végzi azok CD11b/CD18 receptorain keresztül (Johansson és mtsi. 1997). Az enzimatikusan inaktív MPO az endotél sejtekben az IL6 és IL8 citokinek termelését indukálja (Lefkowitz és mtsi. 2000).

Az extracelluláris effektor funkciót ellátó NET legfőbb összetevője a sejtek DNS-e, de tartalmaz a granulumokból felszabaduló fehérjéket, mint például elasztázt, mieloperoxidázt vagy lektoferrint is. A neutrofilek baktérium- (Brinkmann és mtsi. 2004) és gombaölő (Urban és mtsi. 2006) mechanizmusaiban is van szerepe.

A NET képzés szabályozása kevésbé ismert. A legtöbb kutatás szerint a hálózat megjelenése függ a ROS képzéstöl (Fuchs és mtsi. 2007), de ezek a kutatások főképp az intracelluláris ROS általi szabályozásra vonatkoznak (Stoiber és mtsi. 2015). Megfigyeltek ROS független NET képzést (Arai és mtsi. 2014) és a csapda hiányát ROS jelenlétében is. Tehát a ROS valószínúleg szükséges, de nem egyedüli szabályozója a NET megjelenésének (Yost és mtsi. 2009). Nishinaka és munkatársai (2011)eredményei alapján a szinglet oxigén a NET képzés legfontosabb inducere, azonban más kutatások ennek a hipotézisnek ellent mondanak: a pH változás befolyásolja a neutrofil funkciókat, így a NET kialakulását: az intra- és extracelluláris savasodás gátolja a ROS termelést, ezáltal a NET képzést, azonban 
savas környezetben is indukálható a NET kialakulása $\mathrm{H}_{2} \mathrm{O}_{2}$ hozzáadásával (Behnen és mtsi. 2017), tehát a $\mathrm{H}_{2} \mathrm{O}_{2}$ is szerepet játszik a szabályozásban.

Nem csak a ROS-ok válthatnak ki NET képzést, hanem egyes gyulladásos citokinek, mint az IL8, TNFa (Keshari és mtsi. 2012) vagy mikrobiális szignálok, mint az LPS (Brinkmann és mtsi. 2004) jelenléte is képes indukálni azt. Feltételezik továbbá, hogy a hálózat megjelenése függ a patogén méretétől is, ugyanis a Dectin-1 receptoron keresztüli fagocitózis gátolja a kialakulását (Branzk és mtsi. 2014). Egyes esetekben, például Candida albicans jelenlétében, megfigyelték, hogy az MPO is szabályozza a NET kialakulását (Metzler és mtsi. 2011). Ezt az összefüggést azonban Staphylococcus aureus vagy Escherichia coli esetében nem támasztották alá (Parker és mtsi. 2012)

A neutrofil granulociták, akárcsak a monociták és makrofágok, CLR és TLR receptorokon keresztül ismerik fel a gombasejtfali mintázatokat (Thomas és Schroder 2013). A TLR2 és TLR4 receptorok részt vesznek a $\mathrm{H}_{2} \mathrm{O}_{2}$ termelés indukciójában. A TLR4 receptor a neutrofilek élettartamának szabályozásában is szerepet játszik, a stimuláció elnyújtott neutrofil túlélést eredményez a szignál megjelenését követő rövid időszakban, amely egy NF-кB által közvetített útvonalon zajlik, azonban a hosszú távú élethossz-szabályozás már a monociták feladata (Sabroe és mtsi. 2003). A sejtek felszínén jelen lévő Fc receptorok is fontosak az opszonizált (ellenanyaggal vagy komplementfehérjékkel megjelölt) patogének felismerésében (Dale és mtsi. 2008).

\subsubsection{A neutrofil granulociták szerepe a patogén fonalas gombák elleni védekezésben}

Tekintettel arra, hogy a neutropéniás vagy neutrofil funkcióban sérült betegeknél az invazív aszpergillózis kialakulása igen gyakori, a neutrofilek A. fumigatus-sal szemben betöltött kulcsfontosságú védekező szerepe régóta ismert (Young és mtsi. 1970, Cohen és mtsi. 1981). A feohifomikózisok, ezen belül a disszeminált Curvularia fertőzések kialakulásában is kockázati tényezőt jelent a neutropénia, a fertőzést követően a neutrofil funkció helyreállítása pedig növeli a túlélés esélyét (Ben-Ami és mtsi. 2009).

A neutrofil granulociták az Aspergillus konídiumokat és hifákat különböző módon ismerik fel (9. ábra). A konídiumokat opszonizáció nélkül is képesek fagocitálni a CR3 receptoron keresztuil, amelyek csírázását nem oxidatív folyamatokon keresztül gátolják. A csírázás gátlása föképp a laktoferrinek általi vaskötés következtében történik. A hifák 
felismerése opszonizációhoz kötött, Fc receptoron keresztül történik. Azok ölésében nagy szerepe van az oxidatív folyamatoknak (Gazendam és mtsi. 2016).
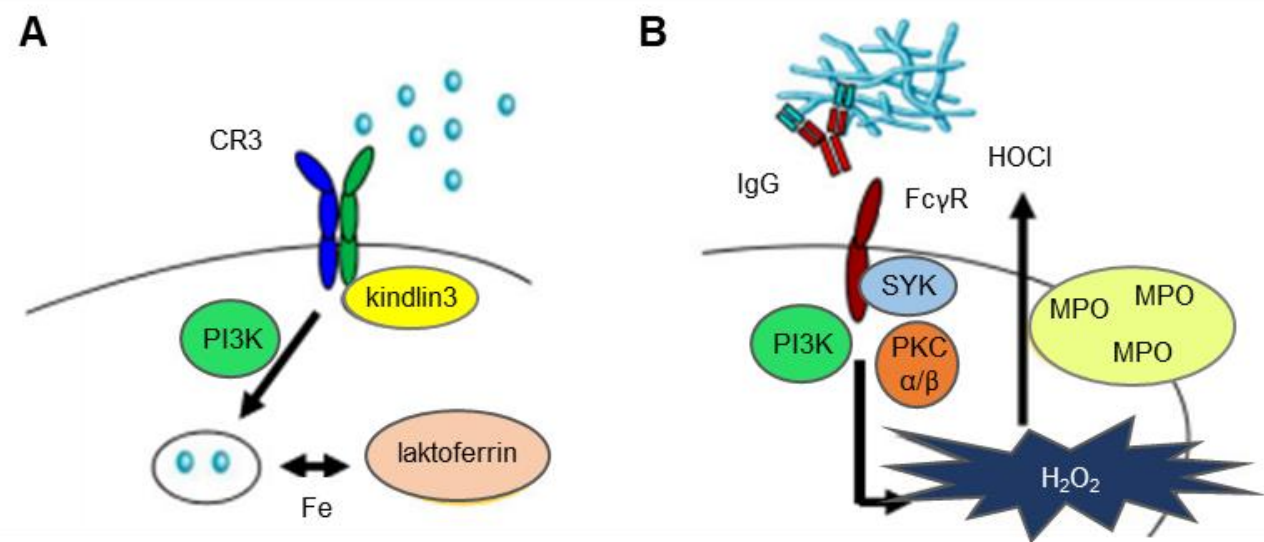

9. ábra: A) Az A. fumigatus konídiumok által kiváltott jelátviteli folyamat, amely nem oxidatív ölési mechanizmust indukál, B) a hifák felismerését követő jelátviteli folyamat, amely az oxidatív burst indukálásához vezet (Gazendam és mtsi. 2016). CR3: komplement receptor 3; FCүR: FC gamma receptor; $\mathrm{H}_{2} \mathrm{O}_{2}$ : hidrogén peroxid; $\mathrm{HOCl}$ : hipoklórossav; IgG: immunoglobulin $\mathrm{G}$; MPO: mieloperoxidáz; PI3K: foszfoinozitid 3-kináz; PKC: protein kináz C; SYK: Spleen tirozin kináz.

Clark és munkatársai (2018) eredményei alapján a CR3 receptor valószínűleg a hifák felismerésében is szerepet játszik, ugyanis a NET képzés szabályozásával is összefüggésbe hozható, valamint a $\beta$-glükán a receptoron keresztül a ROS képzést is indukálja. Ebben a kísérletben a Dectin-1 szerepe a felismerésben nem volt bizonyítható. Egy másik tanulmány szerint azonban a Dectin-1 knockout egerekből származó neutrofilek NADPH-oxidáz komplex aktivációja duzzadt és csírázó konídiumok jelenlétében elmaradt, ölési képességük csökkent (Werner és mtsi. 2009).

A Dectin-1 receptornak valószínüleg fontos szerepe van a Curvularia fajok felismerésében is, hisz a Dectin-1-hez kötött jelátvitelben is szerepet játszó CARD9 fehérje hiánya vagy helytelen müködése kockázati tényezőként szerepel az ezen gombák által okozott feohifomikózisok kialakulásában (Wang és mtsi. 2018).

A krónikus granulomatózus betegségben (CGD) szenvedők NADPH-oxidáz funkció hiányában elégtelen neutrofil válasszal rendelkeznek (Arnold és Heimall 2017). A CR3 receptor a CGD-s betegek esetében is szerepet játszik a gomba felismerésében, ebben az esetben azonban nem-oxidatív ölési mechanizmusokat aktivál (Gazendam és mtsi. 2016). CGD esetén nem figyelhető meg NET formálás (Fuchs és mtsi. 2007). Ezekben a betegekben a halálozás egyik fő oka az invazív aszpergillózis (Winkelstein és mtsi. 2000, Seger 2008). 
A NADPH-oxidáz génterápiás komplementálása helyreállította a NET képzést, így a neutrofilek képesek voltak eliminálni az A. nidulans spórákat és hifákat (Bianchi és mtsi. 2009).

A NET ölési mechanizmusban betöltött szerepe Aspergillus esetében ennek ellenére kérdéses. McCormick és munkatársai (2010) tanulmánya alapján a NET szerepet játszik a gomba növekedésének gátlásában, azonban Gazendam és munkatársai (2016) nem tapasztaltak változást az ölési hatékonyságban A. fumigatus-szal szemben akkor sem, ha a NET kialakulását gátolták.

\subsection{A THP-1 sejtvonal - a monocita-makrofág sejtek modellrendszere}

A THP-1 sejtvonal egy spontán immortalizálódott monocita szerủ sejtvonal, amelyet egy leukémiás gyermek perifériás véréből izoláltak. Fagocitózisra képes sejtek, HLA tipizálás alapján HLA-A, HLA-B és HLA-DR antigén található a felszínükön (Tsuchiya és mtsi. 1980). A monocita állapotú THP-1 sejt a CD14 markert kis mennyiségben expresszálja (Bosshart és Heinzelmann 2016).

A HLA-DR gén által kódolt MHC II molekula részt vesz az antigén prezentációban, valamint általa nyomon követhető a sejtek aktiváltsági állapota is (Baqui és mtsi. 1999). A sejtvonal esetében a HLA molekulák közül a HLA-DR expressziója konstitutív, míg a DP és DQ IFN- $\gamma$ dependens (Yunis és mtsi. 1989). Az aktiválódás detektálására a CCR2 molekula szintén alkalmas, hiszen a monocita állapotú THP-1 sejtek makrofággá történő differenciációjában a CCR2 kifejeződése a primer klasszikus monocitákra jellemző mintázatot mutatja. A CCR1 mRNS szintủ alulszabályozása nem mutatható ki a THP-1 sejtek differenciációjakor (Phillips és mtsi. 2005). A sejtvonal a monociták adhéziós molekuláit is expresszálja, az ITGAL (CD11a), ITGAM (CD11b), ITGAX (CD11c) integrinek vizsgálata szintén következtetni enged a sejtek aktiváltsági állapotára (Baqui és mtsi. 1999).

A monocita sejtek érett makrofág fenotípusú sejtté differenciáltathatók forbol-12mirisztát-13-acetát (PMA) vagy 1,25-dihidroxivitamin $\mathrm{D}_{3}\left(\mathrm{VD}_{3}\right)$ használatával (Schwende és mtsi. 1996).

A THP-1 sejtek monocita és makrofág állapotban is képesek citokinek és kemokinek termelésére (Schutte és mtsi. 2009). A sejtvonal gyakran használt modellje a monocita és 
makrofág funkciók vizsgálatának (Chanput és mtsi. 2014), gomba-immunsejt interakciók tanulmányozására is használják (Thuer és Gabaldon 2017, Hymery és mtsi. 2017)

\subsection{A neutrofil granulociták modellrendszerei}

Mint minden sejttípusnál, a neutrofil granulociták modellezéséhez is használhatók a vérből izolált primer sejtek, vagy rendelkezésre állnak immortalizált sejtvonalak is (pl. HL60, NB4). Mindkét modellrendszernek vannak erősségei és gyengeségei. A sejtvonalak nem minden funkcióban azonosak a primer sejtekkel, viszont könnyebben hozzáférhetők. A primer sejtek funkcióját ugyanakkor befolyásolhatja a donor állapota, az izoláció hatékonysága és egyes lépései. A neutrofil granulociták esetében az izolálásnál visszamaradt monocita populáció is hatással van a neutrofilek túlélésére (Sabroe és mtsi. 2003). 


\section{Célkitüzések}

A fonalas gombák elleni immunválaszról a legtöbb információnk az A. fumigatus-szal kapcsolatban van, azonban egyre több opportunista humán patogén fonalas gomba fajt vizsgálnak ebből a szempontból. A gombákkal szembeni felismerési és ölési mechanizmusok a szakirodalmi adatok alapján eltérőek lehetnek.

Munkánk során a klinikai mintákból leggyakrabban izolált Curvularia fajok reprezentatív törzsei, elsősorban a $C$. lunata által kiváltott természetes immunválaszt vizsgáltuk. Hogy képet kapjunk a folyamatok csoporton belüli diverzitásáról, egyes kísérleti elrendezések esetében a Curvularia nemzetség egyéb fajait is bevontuk a vizsgálatokba.

Ezen vizsgálatokhoz a következő célkitüzéseket fogalmaztuk meg:

1. THP-1 monocita sejtvonal interakciójának vizsgálata $C$. lunata, $C$. hawaiiensis és C. spicifera törzsekkel, amely kiterjed a hifák és a konídiumok által kiváltott válasz, az ölési hatékonyság, valamint a melanin fagocitózisgátló szerepének vizsgálatára;

2. THP-1 sejtekböl érlelt makrofágok interakciójának vizsgálata $C$. lunata, $C$. hawaiiensis és $C$. spicifera törzsekkel, amely során a fagocitózis mértékét és az ölési hatékonyságot kívántuk megállapítani;

3. Primer neutrofil granulociták interakciójának vizsgálata C. lunata-val, ezen belül a felismerési és ölési mechanizmusok, az ölési hatékonyság és a gomba védekező mechanizmusainak feltérképezése. 


\section{Anyagok és módszerek}

\subsection{Az alkalmazott gombatörzsek: tenyésztés, spóraszuszpenzió készítése}

A kísérletek során négy Curvularia és egy Aspergillus fumigatus izolátumot használtunk, amelyeket az 1. táblázat mutat be.

1. táblázat: A kísérletek során használt gombatörzsek, azok törzsgyüjteményi száma, valamint izolálási helyük.

\begin{tabular}{lccc}
\hline Faj & $\begin{array}{c}\text { Törzsgyüjteményi } \\
\text { szám }\end{array}$ & Forrás & Származási hely \\
& SZMC 23759 & Humán keratomikózis & India \\
\hline Curvularia lunata & SZMC 13064 & Humán keratomikózis & Coimbatore, India \\
Curvularia spicifera & CBS 103.97 & Humán szinuszitisz, & Giessen, \\
Curvularia hawaiiensis & & agyi érintettséggel & Németország \\
& SZMC 13061 & Humán keratomikózis & Coimbatore, India \\
Curvularia hawaiiensis & SZMC 23245 & Humán keratomikózis & Horvátország \\
Aspergillus fumigatus & & & \\
& & &
\end{tabular}

\subsection{Alkalmazott sejtkultúrák}

THP-1: akut mieloid leukémiás beteg perifériás véréből származó monocita-szerủ sejtvonal (ATCC TIB-202).

Neutrofil granulociták: egészséges felnőtt donorok perifériás véréből izolált polimorfonukleáris sejtek.

\subsection{Alkalmazott tápközegek, oldatok, reagensek és pufferek}

Burgonya-dextróz táptalaj (Potato dextrose agar; PDA; VWR): 0,4\% burgonya pepton, $2 \%$ glükóz, 1,5\% agar.

Rizslisztes táptalaj (Rice flour agar; RFA): 1\% rizsliszt, 0,2\% élesztőkivonat, 2\% agar.

RPMI tápoldat: RPMI-1640 (Sigma-Aldrich), 0,3 mg/l L-glutamin.

THP-1 tápoldat: RPMI-1640 tápoldat (BioWhittaker) kiegészítve $10 \%(\mathrm{~V} / \mathrm{V}) 56^{\circ} \mathrm{C}$-on 40 percig hőinaktivált borjúszérummal (FBS; Euroclone), valamint szükség esetén 100 unit/ml penicillin-sztreptomicinnel (Lonza) és $25 \mu \mathrm{g} / \mathrm{ml}$ amfotericin B-vel (Gibco). 
Módosított Krebs-Ringer foszfát puffer (mKRPG): $145 \mathrm{mM} \mathrm{NaCl,} \mathrm{4,85} \mathrm{mM} \mathrm{KCl,} \mathrm{5,5} \mathrm{mM}$ glükóz, 5,7 mM Na $2 \mathrm{HPO}_{4}, \mathrm{pH}=7,35$.

Foszfát puffer (PBS): $137 \mathrm{mM} \mathrm{NaCl}, 2,7 \mathrm{mM} \mathrm{KCl}, 10 \mathrm{mM} \mathrm{Na} 2 \mathrm{HPO}_{4}, 2 \mathrm{mM} \mathrm{KH} \mathrm{PO}_{4}$, $\mathrm{pH}=7,4$.

Nátrium-citrát puffer: $10 \mathrm{mM} \mathrm{C} \mathrm{H}_{5} \mathrm{Na}_{3} \mathrm{O}_{7} \cdot 2 \mathrm{H}_{2} \mathrm{O}, \mathrm{pH}=7,2$.

Tripánkék festék: 0,4\% (m/V) tripánkék festék PBS pufferben.

ELISA puffer: $1 \%(\mathrm{~m} / \mathrm{V})$ marha szérumalbumin (Bovine Serum Albumin, BSA; SigmaAldrich) PBS pufferben.

ELISA mosó puffer: 0,05\% (V/V) Tween 20 (Reanal) PBS pufferben.

ELISA szubsztrát puffer: 0,11 M Na-acetát, $\mathrm{pH}=5,5$ (96\% ecetsavval).

TMB oldat: 6 mg/ml TMB (tetrametilbenzidin, Sigma-Aldrich) DMSO-ban oldva.

ELISA szubsztrát oldat: $0,1 \mathrm{mg} / \mathrm{ml}$ végkoncentrációjú TMB és $0,003 \%$ (V/V) $\mathrm{H}_{2} \mathrm{O}_{2}$ ELISA szubsztrát pufferben.

ELISA stop oldat: $1,8 \mathrm{M} \mathrm{H}_{2} \mathrm{SO}_{4}$.

FACS puffer: 0,05\% (V/V) Tween 20 (Reanal) PBS pufferben.

MTT oldat: $0,5 \%(\mathrm{~m} / \mathrm{V})$ 3-(4,5-dimetilthiazol-2-il)-2,5-difeniltetrazolium bromid RPMI1640-ben oldva.

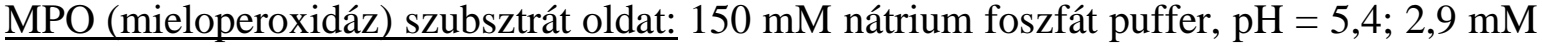
3,3',5,5'-tetrametilbenzidin; $0,05 \mathrm{mM} \mathrm{H}_{2} \mathrm{O}_{2}$.

Inhibitoros MPO szubsztrát oldat: $150 \mathrm{mM}$ nátrium foszfát puffer $\mathrm{pH}$ 5,4; 2,9 mM 3,3',5,5'tetrametilbenzidin, 0,05 $\mathrm{mM} \mathrm{H} \mathrm{O}_{2}, 1 \mathrm{mM}$ 4-amino benzhidrazid.

Savas izopropanol: $95 \%(\mathrm{~V} / \mathrm{V})$ izopropanol, $5 \% 1 \mathrm{~N} \mathrm{HCl}$.

\subsection{Gombatörzsek tenyésztése, konídium-szuszpenzió készítése}

\subsubsection{Tenyésztés szilárd táptalajon}

A felhasznált gombatörzseket PDA táptalajon tartottuk fenn. A kísérletekhez a konídiumokat 7 vagy 14 napig PDA illetve 7 napig RF táptalajon nevelt tenyészetekről, PBSsel vagy mKRPG-vel mostuk le. A hifatörmeléktől a Curvularia izolátumok esetében $45 \mu \mathrm{m}$ pórusátmérőjü szürő (Millipore) segítségével szabadultunk meg.

A melanin bioszintézis gátlására a PDA táptalajt $20 \mu \mathrm{g} / \mathrm{ml}$ triciklazollal (SigmaAldrich) és $1 \%$ agarral (Merck) egészítettük ki. 


\subsubsection{Tenyésztés folyékony tápoldatban, $\mathrm{H}_{2} \mathrm{O}_{2}$ indukció}

A gombatörzseket a folyadéktenyészetben történő neveléséhez 100 ml-es Erlenmeyer lombikba, $50 \mathrm{ml}$ RPMI tápoldatba $10^{3}$ konídium/ml koncentrációban oltottuk le. A tenyészeteket $37{ }^{\circ} \mathrm{C}$-on, folyamatosan rázatva neveltuik 5 napig. A tenyészeteket $\mathrm{H}_{2} \mathrm{O}_{2}$-dal indukáltuk (0,2 mM végkoncentrációban), majd 30 vagy 60 perc múlva gézlapon leszürtük. A mintákat felhasználásig $-80{ }^{\circ} \mathrm{C}$-on tároltuk.

\subsection{Sejtvonalak tenyésztése, primer sejtek izolálása}

\subsubsection{THP-1 sejtvonal tenyésztése és differenciáltatása}

A sejtvonalat antibiotikummal kiegészített THP-1 tápoldatban tartottuk fenn, $37{ }^{\circ} \mathrm{C}$ on, $5 \% \mathrm{CO}_{2}$ és $100 \%$ relatív páratartalom mellett. A kísérletek előtt minimum egy átoltási ciklus során antibiotikum nélkül neveltük a sejteket.

A differenciáltatáshoz a sejteket a kísérlethez szükséges végkoncentrációban osztottuk 12 vagy 24 lyukú sejttenyésztő lemezekre. A differenciáltatást 24 órán keresztül végeztük 10 nM forbol-mirisztil-acetáttal (PMA) kiegészített THP-1 tápoldatban, 1 ml végtérfogatban. A PMA eltávolítása után a sejteket 24 órán keresztül $37{ }^{\circ} \mathrm{C}$-on, $5 \% \mathrm{CO}_{2}$ és $100 \%$ relatív páratartalom mellett inkubáltuk.

\subsubsection{Primer neutrofil granulociták izolálása}

A sejteket 20-50 éves, egészséges donorokból származó vénás vérből izoláltuk. A vér heparin tartalmú csőbe (BD Vacutainer) került levételre. A neutrofil granulociták izolálását a korábban már leírt dextrán (Sigma-Aldrich) szedimentációt követő Ficoll-Paque grádiensen (GE Healthcare) történő centrifugálással végeztük (Kuhns et al. 2015). Az eritrociták lízise hipozmotikusan történt. A sejtek spontán aktivációjának elkerülése érdekében az izolálást

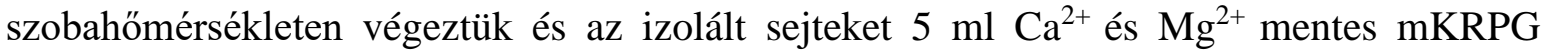
pufferben vettük fel. 


\subsection{Kísérleti módszerek}

\subsubsection{Humán szérum izolálás}

Az opszonizációhoz használt humán szérumot minden donor esetében saját vénás vérből izoláltunk. A vér szeparátor géllel töltött vérvételi csőbe került levételre. A szérum elválasztásához a megalvadt vért $25{ }^{\circ} \mathrm{C}$-on $1200 \mathrm{rpm}$-en 15 percig centrifugáltuk.

\subsubsection{Fertőzési körülmények}

\section{THP-1 sejtvonal fertőzése}

A THP-1 monociták fertőzését 6 vagy 12 lyukú sejttenyésztő lemezen végeztuik, a sejteket a fertőzést megelőző napon osztottuk $10^{5}$ sejt/ml koncentrációban, $3 \mathrm{ml}$ vagy $1 \mathrm{ml}$ végtérfogatban.

Mind a monocita, mind pedig a makrofág sejtekhez 1:20 vagy 2:1 effektor:target (E:T) arányban adtunk élő vagy hőinaktivált konídiumokat $100 \mu$ l PBS-sel készített szuszpenzióban, majd a lemezeket meghatározott ideig (3, 9 vagy 24 óra) $37{ }^{\circ} \mathrm{C}$-on, $5 \% \mathrm{CO}_{2}$ és $100 \%$ relatív páratartalom mellett inkubáltuk. Az inkubációs idő leteltével gyüjtött felülúszót felhasználásig $-20{ }^{\circ} \mathrm{C}$-on tároltuk.

A spórák hőinaktiválását 25 percig $125^{\circ} \mathrm{C}$-on végeztük.

\section{Primer neutrofil granulociták fertőzése}

A kísérletekben csíráztatott konídiumok és neutrofil granulociták interakcióját vizsgáltuk. A 96 lyukú lemezen (Sarstedt) a csíráztatást $\left(2 \times 10^{4}\right.$ konídium/well) $37{ }^{\circ} \mathrm{C}$-on, mKRPG-ben végeztük, $C$. lunata esetében 4 órán, $A$. fumigatus esetében 8 órán át $100 \mu 1$ végtérfogatban, amely után a sejteket $100 \mu$ l térfogatban adtuk a gombákhoz a konídiumokhoz viszonyított 5:1 arányban. A CELLview üvegaljú sejttenyésztő petricsészére (Greiner Bio-One) $7 \times 10^{4}$ konídiumot oltottunk le $400 \mu$ l végtérfogatban. A csíráztatás után a sejteket $400 \mu \mathrm{l}$ térfogatban adtuk a gombákhoz 5:1 arányban.

Négy kísérleti körülményt állítottunk fel:

1. Felülúszóval: a konídiumok csírázását követően az izolált sejteket közvetlenül adtuk a gombákhoz.

2. Felülúszó nélkül: a csíráztatás után a csírázó konídiumokat friss mKRPG-vel mostuk, majd a sejteket a friss pufferben adtuk a gombákhoz. 
3. Szérum opszonizált: a gombákat a konídiumok csíráztatásának utolsó órájában $10 \%$ (V/V) szérum hozzáadásával opszonizáltuk, majd a sejteket így adtuk a gombákhoz.

4. Felülúszó kezelt: a sejtekhez a csírázó konídiumok gombamentes felülúszójának 100 $\mu 1$-ét adtuk.

Lipopoliszachariddal (LPS) történő indukció

Az LPS-sel történő indukcióhoz Escherichia coli Q26:B6 (Sigma-Aldrich) lipopoliszacharidot használtunk, $1 \mu \mathrm{g} / \mathrm{ml}$ végkoncentrációban.

\subsubsection{Fagocitózis vizsgálat}

A fagocitózis vizsgálatot 12 lyukú lemezeken végeztük, amelyre a monocita THP-1 sejteket a kísérletet megelőző napon osztottuk a mintahelyekbe, $10^{5} \mathrm{sej} / \mathrm{ml}$ koncentrációban. A makrofágok vizsgálatához a sejteket 24 lyukú lemezen, $3 \times 10^{5}$ sejt $/ \mathrm{ml}$ koncentrációban indukáltuk a korábban leírt módon. A kísérlet elött 4 órával a sejteket félszeres koncentrációban festettük 15 percen át CellMask Deep Red Plasma Membrane stain (Thermo Scientific) festékkel, majd kétszer mostuk $37{ }^{\circ} \mathrm{C}$-ra előmelegített PBS-sel.

A konídiumokat AlexaFluor 488 karboxilsav, szukcinimidil észterrel (Thermo Scientific) festettük $4{ }^{\circ} \mathrm{C}$-on 15 percig, majd kétszer mostuk PBS-sel. Az interakcióhoz 1:2 vagy 20:1 (E:T) arányban fertőztük a sejteket. Az inkubációs idő lejárta után a sejteket felmostuk, majd 15 perc 1000 rpm-en történő centrifugálás után $200 \mu$ l FACS pufferben felszuszpendáltuk. A mérést FlowSight Imaging Flow Cytometer-rel (Amnis) végeztük, az adatokat IDEAS Software (Amnis) segítségével értékeltük ki.

\subsubsection{Enzimhez kapcsolt immunoszorbens vizsgálatok (ELISA)}

Az interakciók során a sejtekből felszabaduló citokinek mennyiségét ELISA eljárással határoztuk meg, a következő kiteket használva: Human TNF- $\alpha$ DuoSet ELISA Kit (R\&D Systems), Human IL-1 $\beta$ DuoSet ELISA Kit (R\&D Systems), Human IL-6 DuoSet ELISA Kit (R\&D Systems), Human IL-8 DuoSet ELISA Kit (R\&D Systems) és Human IL-10 ELISA (Immunotools). A méréseket a gyártók utasításai szerint végeztük. A mosást minden esetben négyszer végeztük ELISA mosó pufferrel. Az elsődleges antitestet 96 lyukú NUNC Immuno-plate F96 MaxiSorp (Thermo Scientific) lemezre vittük fel egy éjszakán át történő szobahőmérsékletü inkubálással. A lemezeket mosás után ELISA pufferrel 1 órán át 
blokkoltuk. Újabb mosás után a mintahelyekre felvittük az ELISA pufferben hígított citokin standardokat vagy a mintákat 2 technikai párhuzamosban, majd szobahőmérsékleten 2 órán át inkubáltuk. Mosást követően adtuk hozzá a másodlagos, biotinált antitestet a mintákhoz, amelyet 2 órán át, szobahőmérsékleten kötöttünk fel. Mosás után ELISA pufferben hígított sztreptavidin-HRP oldatot mértünk a mintahelyekbe. 20 perc inkubálás után mostuk a mintákat és $100 \mu \mathrm{l}$ friss ELISA szubsztrát oldatot adtunk hozzájuk. A megfelelő színintenzitás elérése után $100 \mu$ l ELISA stop oldattal állítottuk le a reakciót. A fényelnyelést 450 nm-en, SPECRTOStar Nano Microplate Reader (BMG Labtech) segítségével határoztuk meg. Az adatokat a MARS Data Analysis szoftverrel (BMG Labtech) elemeztük. A citokinek mennyiségi meghatározásához négy paraméteres logisztikus modell alapján létrehozott standard görbét használtunk.

\subsubsection{Gomba életképesség meghatározás}

Az immunsejt-gomba interakciókat követő hifakárosodás mértékét MTT (3-(4,5dimetil tiazol-2-il)-2,5-difenil-tetrazólium-bromid) vizsgálattal határoztuk meg. A metabolikusan aktív sejtek a sárga színü MTT-t kék formazán-kristályokká alakítják át, amelyek a gomba sejtfalába épülnek be. A vizsgálatoknál meghatározott interakciós idő leteltével a lemezek mintahelyeiröl a felülúszót eltávolítottuk, majd a sejteket 0,5\%-os nátrium-deoxikolát hozzáadásával lizáltuk. A sejttörmeléket PBS-sel történő mosással távolítottuk el, majd $200 \mu \mathrm{l}$ vagy $1 \mathrm{ml}$, a kísérletnek megfelelő pufferben vagy tápoldatban oldott, 0,5\%-os (m/V) MTT (Sigma) hozzáadása után a lemezeket $37{ }^{\circ} \mathrm{C}$-on 3 órát inkubáltuk. Ezután a mintákat háromszor mostuk PBS-sel, majd egy éjszakán át $-20{ }^{\circ} \mathrm{C}$-on tároltuk. Ezt követően $200 \mu 1$ savas izopropanolt (19:1 arányú izopropanol és $\mathrm{HCl}$ ) adtunk a gombákhoz, majd a formazán-kristályok feloldódásáig inkubáltuk szobahőmérsékleten. A felülúszót új mikrotiterlapra vittük át, majd a fényelnyelést 550 nm-en mértük SPECTROStar Nano Microplate Reader (BMG Labtech) készülékkel. Az életképességet a következő képlet alapján számoltuk, ahol OD550 minta a sejtekkel ko-inkubált hifára vonatkozó fényelnyelés, míg OD550 kontroll a sejtek nélkül inkubált hifa esetében mért fényelnyelés:

$$
\text { Életképesség }=\left(\frac{\text { OD550 minta }}{\text { OD550 kontroll }}\right) \times 100 .
$$




\subsubsection{Mieloperoxidáz (MPO) aktivitás mérése}

A neutrofil granulocitákból felszabaduló mieloperoxidáz mennyiségének meghatározását 96-lyukú lemezen végeztük. Az MPO felszabadulást a ko-inkubáció 30. és 60. percében mértük a sejtmentes felülúszóból. A reakcióelegy a következő összetevőket tartalmazta: $30 \mu \mathrm{l}$ minta, $150 \mu \mathrm{l}$ szubsztrát oldat / inhibitoros szubsztrát oldat. A reakcióelegyet 5 percig $37{ }^{\circ} \mathrm{C}$-on inkubáltuk, majd a reakciót $70 \mu$ ELISA stop oldat hozzáadásával állítottuk le. A mérést 450 nm-en végeztük SPECTROstar Nano Microplate Reader (BMG Labtech) készülékkel. Kontrollként vizsgáltuk a neutrofil granulociták spontán mieloperoxidáz termelését, amelyhez fertőzés nélküli sejteket használtunk. A számolás során a hozzáadott szubsztrátot tartalmazó minták OD450nm értékéből kivontuk az inhibitoros minták OD $450 \mathrm{~nm}$ értéket, így megkapva a kizárólag MPO aktivitásból származó értékeket. A mennyiségi meghatározáshoz Recombinant Human Myeloperoxidase Protein, CF (R\&D) hígítási sorából felvett standard görbét használtunk.

\subsubsection{Reaktív oxigéngyökök (ROS) mérése}

Az extracelluláris $\mathrm{H}_{2} \mathrm{O}_{2}$ termelést Amplex Red Hydrogen Peroxide/Peroxidase Assay Kit-tel (Thermo Scientific) mértük, a gyártó leírása alapján. A minták méréséhez használt excitációs és emissziós hullámhossz 560 és 590 nm volt. A mérést a ko-inkubáció 30. és 60 . percében végeztük Fluostar Optima (BMG Labtech) készülékkel. A mérések során kontrollként vizsgáltuk a neutrofil granulociták fertőzés nélküli, spontán extracelluláris $\mathrm{H}_{2} \mathrm{O}_{2}$ termelését. A kiértékelés során a 30 és 60 perc elteltével mért értékekből kivontuk a spontán felszabaduláskor mért értékeket. A mennyiségi meghatározáshoz $\mathrm{H}_{2} \mathrm{O}_{2}$ hígítási sorból mért értékekből felvett standard görbét használtunk.

\subsubsection{NET képzés vizsgálata}

A neutrofil granulociták által létrehozott extracelluláris csapdát (NET) az interakció harmadik órájában, CELLview (Greiner Bio-One) csészén vizsgáltuk. A mintákat 1\% formaldehid oldattal 15 percig fixáltuk. A festéseket nátrium-citrát pufferben, szobahőmérsékleten, fénytől védve végeztük. A DNS-t 167 nM SYTOX Green-nel (Life Technologies) 30 percig, a kitint $5 \mu \mathrm{g} / \mathrm{ml}$ koncentrációjú Calcofluor White-tal (Cyanamid) 15 percig, a sejtmembránt félszeres koncentrációjú CellMask Deep Red plazma membrán 
festékkel (Life Technologies) 15 percig festettük. A festési lépések között és a festés után a mintákat kétszer mostuk nátrium-citrát pufferrel.

A mikroszkópos vizsgálatot Zeiss Axio Observer fluoreszcens inverz mikroszkóppal végeztuik. A NET képzésben részt vevő sejtek százalékos arányát ImageJ képanalízissel határoztuk meg Gonzalez és mtsi. (Gonzalez és mtsi. 2014) által leírt protokol alapján kisebb módosítással. Röviden a SYTOX Green által megfestett terület kiterjedését határoztuk meg minden fókuszban lévő sejt esetében, amely alapján a sejteket 3 csoportba osztottuk: az intakt sejtmag esetében a DNS kiterjedése kisebb vagy egyenlö, mint $50 \mu^{2}$, felbomlott sejtmagmembrán esetén $50-90 \mu \mathrm{m}^{2}$, míg netotikus sejt esetén nagyobb, mint $90 \mu \mathrm{m}^{2}$. Az egyes körülmények vizsgálatára minimum 6 képet elemeztünk.

\subsubsection{Az extracelluláris pH meghatározása}

Az extracelluláris pH-t, a gomba-neutrofil granulocita interakció 3. órájában, a sejtmentes felülúszóban határoztuk meg kalibrációs egyenes segítségével. A kalibrációs egyenes felvételéhez különböző pH-jú mKRPG puffert használtunk. A felülúszó 100 l-éhez $5 \mu 1$ 2\% lakmusz oldatot (CPAChem) adtunk 96 lyukú lemezen, a színváltozást 580 nm-en SPECTROstar Nano Microplate Reader (BMG Labtech) segítségével mértük.

5.6.10 A melanin tisztítása és vizsgálata

A C. lunata neutrofil granulocitákkal való interakciója, valamint a gomba mKRPG közegben történő tenyésztése során vizsgáltuk a melanin termelést. Az interakcióból származó tápközeget 6000 rpm-en 10 percig centrifugáltuk, a tenyésztésböl származó mKRPG-t pedig gézlapon szürtük. A felülúszókat tömény $\mathrm{HCl}$ hozzadásával $\mathrm{pH}=2$-ig savanyítottuk, amely hatására a melanin kiválása figyelhető meg. A savanyítás után a felülúszókat 0,2 $\mu \mathrm{m}$ poli(tetrafluoroetilén) (PTFE) membránszürőn szürtük (Goncalves, Lisboa and Pombeiro-Sponchiado 2012), amellyel a csapadék felfogható. 
5.6.11 RNS izolálás, cDNS szintézis és kvantitatív valós idejű reverz transzkripció (qRT) PCR analízis

qRT-PCR sejttenyészetből

A THP-1 sejtekből történő totál RNS izoláláshoz RNeasy Mini kitet (Qiagen) használtunk, a gyártó utasításai alapján. Az eluálási térfogat $20 \mu \mathrm{l}$ volt. Az izolált RNS tisztaságát és koncentrációját ND-1000 Spectrophotometer (Nano Drop) ellenőriztük.

A reverz transzkripcióhoz SuperScript VILO Master Mixet (Invitrogen) használtunk a gyártó utasításai szerint.

A relatív transzkripciós szintek meghatározása StepOne Plus Real-Time PCR System (Applied Biosystems) segítségével történt. A reakciókat TaqMan Gene expression Master Mix (Applied Biosystems) vagy Sybr Select Master Mix (Applied Biosystems) felhasználásával mértük össze. Az indítószekvenciákat és a próbákat a 2., illetve a 3. táblázat foglalja össze. A relatív transzkripciós szinteket $18 \mathrm{~S}$ rRNS-re normalizálva, $\Delta \Delta \mathrm{C}_{\mathrm{T}}\left(2^{-\Delta \Delta \mathrm{Ct}}\right)$ módszerrel (Livak and Schmittgen 2001) számoltuk ki.

2. táblázat: a THP-1 sejttenyészeteknél alkalmazott indítószekvenciák összefoglaló táblázata.

\begin{tabular}{ccc}
\hline Target gén & Forward $\left(\mathbf{5}^{\prime} \mathbf{- 3}\right.$ ') indítószekvenciák & Reverz (5' -3') indítószekvenciák \\
\hline$C C R 1$ & TCTACGCCTTCGTTGGTGAG & TTTAACCAGGTGCACAGCCA \\
$C C R 2$ & TACCAACGAGAGCGGTGAAG & GCATGTTGCCCACAAAACCA \\
$C C R 5$ & TTACTGTCCCCTTCTGGGCT & AAGCAAACACAGCATGGACG \\
$C X C R 2$ & TTTCGCCATGGACTCCTCAA & GTAGTGGAAGTGTGCCCTGA \\
$I L I B$ & AGCTGGAGAGTGTAGATCCCAA & GGGAACTGGGCAGACTCAAA \\
$I T G A L$ & GCAAGGACATACCGCCCAT & TACTCAGGCTCAGCTCCACA \\
$I T G A M$ & AGTCTGCCTCCATGTCCAGAA & CTGCGTGTGCTGTTCTTTGTC \\
$I T G A X$ & AGTCTGCCTCCATGTCCAGAA & CTGCGTGTGCTGTTCTTTGTC \\
$H L A D R A$ & CCGATCACCAATGTACCTCCA & CGAAGCCACGTGACATTGAC \\
\hline
\end{tabular}


3. táblázat : A THP-1 sejttenyészeteknél használt TaqMan próbák azonosítói.

\begin{tabular}{cc}
\hline Target gén & TaqMan azonosító \\
\hline 18S rDNA & Hs99999901_s1 \\
IL10 & Hs00961522_m1 \\
IL6 & Hs00174131_m1 \\
IL8 & Hs00174103_m1 \\
TNFA & Hs00174128_m1 \\
NLRC3 & Hs01054716_m1 \\
\hline
\end{tabular}

\section{qRT-PCR a gomba sejtekböl}

A gombából történő totál RNS izoláláshoz NucleoSpin RNA Plant kitet (MachereyNagel) használtunk. A folyadéktenyészetből a gombahifát gézen való átszüréssel összegyüjtöttük, majd folyékony nitrogénben eldörzsöltük. Az RNS-t a gyártó utasításai alapján izoláltuk. Az eluálási térfogat $50 \mu 1$ volt. Az RNS tisztaságát és koncentrációját ND1000 Spectrophotometer (Nano Drop) ellenőriztük.

A reverz transzkripciót Maxima H Minus First Strand cDNA Synthesis kittel (Thermo Scientific) végeztük. Az átíráshoz qRT-PCR reakciónként 500 ng RNS-ből indultunk ki. A szintézishez oligo(dT)18 és random hexamer primereket használtunk a gyártó utasítása szerint.

A relatív transzkripciós szintek meghatározásához valós idejü PCR reakciót használtunk. A reakciókat Maxima SYBR Green qPCR Master Mix (Thermo Scientific) felhasználásával mértük össze, a gyártó utasításai alapján. A felhasznált indítószekvenciákat az 4. táblázat foglalja össze. A relatív transzkripciós szinteket a $C$. lunata aktin génre normalizálva, $\Delta \Delta \mathrm{C}_{\mathrm{T}}\left(2^{-\Delta \Delta \mathrm{Ct}}\right)$ módszerrel (Livak és Schmittgen 2001) számoltuk ki. 
4. táblázat : A C. lunata-nál használt indítószekvenciák összefoglaló táblázata

\begin{tabular}{ccc}
\hline Target gén & Forward $\left(\mathbf{5}^{\prime} \mathbf{- 3}\right.$ ') indítószekvenciák & Reverz $\left(\mathbf{5}^{\prime} \mathbf{- 3}\right.$ ') indítószekvenciák \\
\hline Aktin & CAAGTCCAACCGTGAGAAGATG & TAGTCAGTCAGATCACGACCAG \\
HPO2 & CTACAAACACCAACGACATCC & GTTTAGCTCCTCGGAAATCAC \\
HPO3 & TACCGCCAATACTTTCCTCCT & TGGTTTCCAATTTCACCGTCTG \\
HPO4 & GTACCTCTTTCTCGCCATTGTC & GGAATAGCCAGGTAAGAGTTGGA \\
HPO5 & CTAGCTCATTTGACGGCTTCC & GTTCCAACAGGCTTCCTAGAC \\
HPO6 & TCCCAAATCATTGCTACCTCCA & CAAGTTCCCGATGATGCCAG \\
HPO7 & CATTGCCTCCTATATCTTTGACTG & GGACAAAGACAAGACAGACGA \\
HPO8 & GACCGCGTCTCTTTCTTGTG & ATTTGCCCTGCGAACATGAG \\
\hline
\end{tabular}

\subsection{Statisztikai analízis}

A kísérleteket két technikai és három biológiai párhuzamosban végeztük. Az adatokat Microsoft Excel és GraphPad Prism 7 szoftverek segítségével elemeztük. A szignifikancia értékeket páros t-próbával, többszörös t-próbával (hamis találati aránnyal, $\mathrm{Q}=10 \%$ ), kétszempontos ANOVA teszttel vagy Kruskal-Wallis teszttel határoztuk meg. $\mathrm{P} \leq 0,05$ (* $\mathrm{p}<0.05 * * * * \mathrm{p}<0.0001)$ érték esetében tekintettük az eredményeket szignifikánsnak.

\section{$5.8 \quad$ In silico szekvencia elemzés}

A haloperoxidáz szerü fehérjéket kódoló géneket a $C$. lunata genomadatbázisában (https://genome.jgi.doe.gov/Coclu2/Coclu2.home.html; (Ohm és mtsi. 2012, Condon és mtsi. 2013) végzett keresés alapján azonosítottuk. A szekvenciákat Expasy MyHits motívum kereső programmal (https://myhits.isb-sib.ch; (Pagni és mtsi. 2007) és NCBI blastP (https://blast.ncbi.nlm.nih.gov/Blast.cgi?PAGE=Proteins) programmal elemeztük. 


\section{Eredmények és értékelésük}

Kísérleteinkben az A. fumigatus-t használtuk kontrollként, hiszen a fonalas gombákra adott immunválasz kutatásában ez a faj az általánosan alkalmazott modellorganizmus és így a legtöbb információ is erről a fonalas gombáról áll rendelkezésünkre.

\subsection{Monociták válasza Curvularia izolátumokra}

A THP-1 monociták válaszát a Curvularia izolátumokra az interakció 1., 3. és 24. órájában vizsgáltuk. A gomba a fertőzéstől számított 1. órában még konídium, a 3. órában csírázó konídium állapotban van (utóbbi esetben tehát megjelenik a fonalas csíratömlő, a csírázás folyamata a leoltástól számítva körülbelül 90 perc elteltével kezdődik), míg a 24. órában már elágazó hifák is megfigyelhetők.

\subsubsection{A THP-1 sejtek C. lunata konídiumokra adott válasza}

A C. lunata konídiumokkal történő interakcióban a sejtek fagocitáló képességét, aktivációját és citokintermelését vizsgáltuk élö és hőinaktivált konídiumok használatával.

Az élö konídiumokkal fertőzött sejtek esetében a fagocitózist egy óra elteltével vizsgáltuk (E:T = 20:1). A sejtek csupán 0,12( $\pm 0,1) \%$-a mutatott pozitív eredményt a fagocitózis tekintetében, ezen események többsége viszont inkább csak sejt-konídium kapcsolat volt, mint tényleges bekebelezés (10/I. ábra).
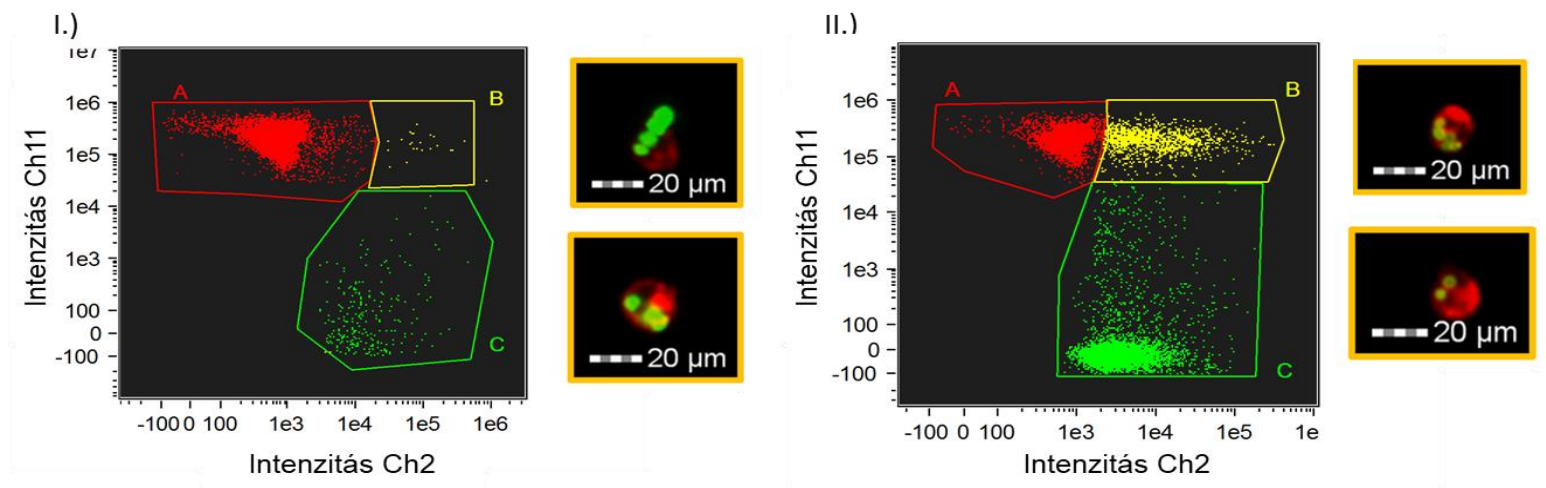

10. ábra: A THP-1 monociták fagocitáló képessége I.) C. lunata (E:T = 20:1) és II.) A. fumigatus (E:T = 1:2) konídiumokkal szemben 1 óra elteltével. Az ábrákon az A (piros) populáció a monocitákat, a B (sárga) a konídiumokkal interakcióban lévő sejteket, míg a C (zöld) a konídiumokat jelenti. A tengelyek a piros (Ch11) és zöld (Ch2) fluoreszcencia intenzitást jelölik. A sárga keretbe foglalt fluoreszcens felvételek a konídiumok és sejtek interakcióit mutatja, ahol zöld színnel a konídium, pirossal a monocita látható. 
Kontrollként végrehajtottuk a fagocitózis vizsgálatot A. fumigatus konídiumokkal szemben is. A fertőzést elvégeztük a szakirodalomban általánosan használt 1:2 (Loeffler és mtsi. 2009) valamint a $C$. lunata-nál általunk használt 20:1 effektor:target arányban is. Egy óra elteltével a fagocitáló sejtek aránya $\mathrm{E}: \mathrm{T}=1: 2$ esetében $20,7( \pm 2,5) \%$ az E:T $=20: 1$ esetében 2,4( $\pm 0,4) \%$ volt (10/II. ábra). Az A. fumigatus csírázási ideje a 6 . órára tehető, a fagocitózis mértékét 3 óra elteltével vizsgálják a szakirodalmi adatok szerint (Loeffler és mtsi. 2009).

A Curvularia esetében a tényleges fagocitózis hiányát magyarázhatja a konídium mérete is, hiszen az A. fumigatus 2-3 um-es spórái (Mullins és mtsi. 1976) elég kicsik, hogy a sejtek akár több konídiumot is képesek legyenek internalizálni (10/II ábra), azonban a $C$. lunata 20-30 ㅆm-es (Kusai és mtsi. 2016, Stappers és mtsi. 2018) konídiumai ezt nem teszik lehetővé (10/I. ábra).

A szakirodalmi adatok alapján a melanin egyes fajok, mint például C. neoformans esetében gátolhatja a fagocitózist (Wang és mtsi. 1995), más fajoknál, mint az $E$. dermatitidis, erre a folyamatra nem volt hatással (Schnitzler és mtsi. 1999). A. fumigatus konídiumainak felismerésében a melaninhoz kötődő MelLec receptor fontos szerepet játszik (Stappers és mtsi. 2018). A C. lunata konídium falának részletes felépítése és benne a melanin helyzete nem ismert. Mivel a melanin hatása a fagocitózisra fajonként eltérö, ezért feltételezhetjük, hogy a $C$. lunata esetében a pigment akár gátolhatja is a sejtek általi felismerést. A hipotézis teszteléséhez a fagocitózist olyan hőinaktivált konídiumokkal is megvizsgáltuk, melyeket melanin bioszintézist gátló körülmények közt nevelt $C$. lunata tenyészetről mostunk le (5.4.1. fejezet).

A hőinaktivált konídiumokkal végzett fagocitózis vizsgálatban a sejteket 3 órán át együtt inkubáltuk a monocitákkal $(E: T=20: 1)$. Ez esetben a sejtek 0,35( $\pm 0,2) \%$-ánál mértünk pozitív eredményt. A melanin felhalmozódásának hiánya a sejtfalban nem befolyásolta a monociták fagocitáló képességét: az ilyen konídiumokkal végzett interakciós kísérletben a sejtek 0,69(ะ0,1)\%-ánál tapasztaltunk interakciót.

Összefoglalva a fentieket elmondható, hogy míg a korábbi vizsgálatokkal összhangban (Loeffler és mtsi. 2009) a THP-1 sejtek aktívan fagocitálták az A. fumigatus konídiumokat, nem voltak képesek erre a Curvularia konídiumok esetében és ez a jelenség nem függött a konídiumok melanizáltságától. Feltételezésünk szerint a kétféle gombára jellemző 
konídiumok markánsan eltérő mérete és sejtfal összetétele lehet az egyik magyarázata a monociták velük szemben tanúsított eltérő fagocitáló képességére.

A monociták és $C$. lunata konídiumok közötti csekély interakció ellenére megvizsgáltuk ezen sejtek konídiumok által kiváltott aktivációját és citokintermelését. Hőinaktivált konídiumokat adtunk a THP-1 sejtekhez, majd 3 és 24 óra elteltével mértük az aktivációhoz és a citokintermeléshez kötődő gének kifejeződését, valamint egyes citokinek mennyiségét.

A monocita sejtek gomba szignálok jelenlétében képesek aktiválódni, amely során az érfalon való átlépéshez, antigén prezentációhoz szükséges molekulák kifejeződése figyelhető meg (Shi és Pamer 2011). Az aktiváció vizsgálatához a CCR1, CCR2, és HLADRA géneket választottuk ki (11. ábra).
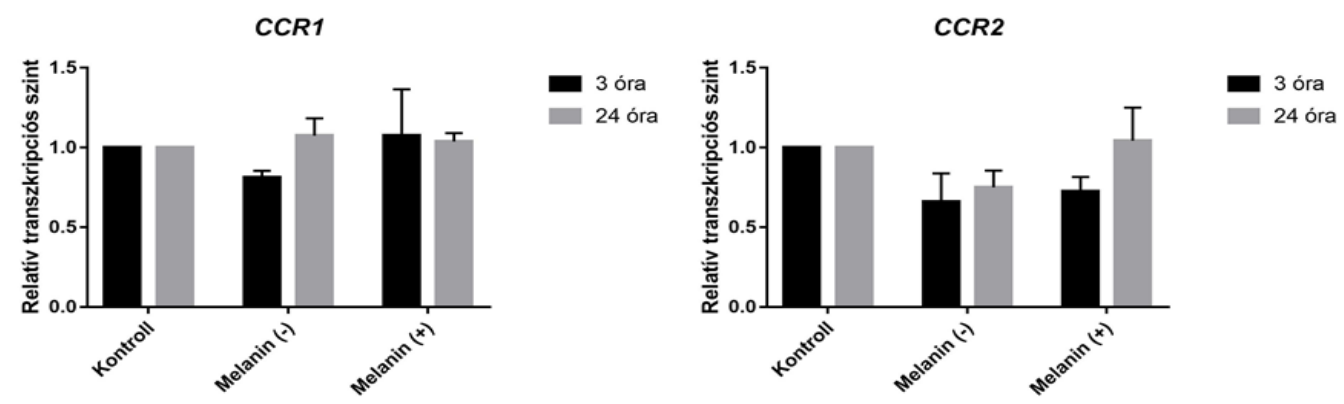

HLADRA

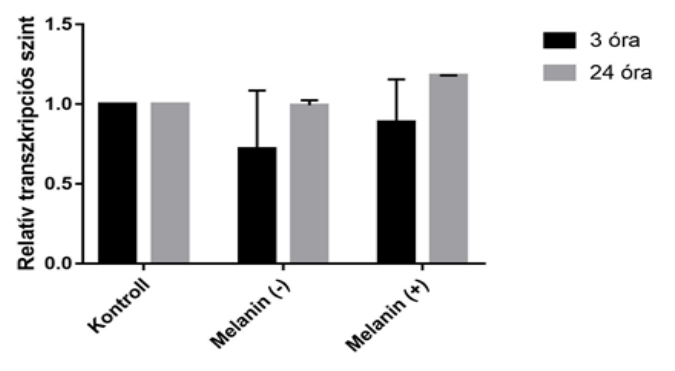

11. ábra: A THP-1 monociták aktivációt jelző génjeinek transzkripciós változása $C$. lunata melanizált [melanin (+)] és melanin gátolt [melanin (-)] hőinaktivált konídiumainak hatására. A relatív transzkripciós szinteket $\Delta \Delta \mathrm{C}_{\mathrm{T}}\left(2^{-\Delta \Delta \mathrm{Ct}}\right)$ módszerrel határoztuk meg. A statisztikai analízist páros tpróbával végeztük el az azonos időpontban mért sejtes kontrollhoz viszonyítva, $\mathrm{n}=3$.

THP-1 sejtek esetén a CCRl gén transzkripciója nem, azonban a CCR2 géné alulszabályozást mutat aktiváció esetén (Phillips és mtsi. 2005). Aktiváció előtt a monociták kevésbé hatékony stimulátorai a $\mathrm{T}$ sejteknek, köszönhetően az alacsony MHCII expressziónak (Laupeze és mtsi. 1999). Az MHCII molekulát kódoló HLADRA gén felülszabályozása is utal a THP-1 monociták aktivációjára, valamint az antigén prezentáció 
jelenlétére is következtethetünk a transzkripciós változásból (Baqui és mtsi. 1999). Sem a melanizált, sem pedig a melanin gátolt $C$. lunata konídiumok nem váltottak ki az aktivációra jellemző transzkripciós változást a vizsgált génekben (11. ábra).

A citokintermelést transzkripciós és fehérje szinten is meghatároztuk. A vizsgált gének esetében nem tapasztaltunk transzkripciós emelkedést, a melanizált konídiumok jelenléte TNFA és IL8 gének szignifikáns alulszabályozását eredményezte 3 óra elteltével a kontrol sejtekhez viszonyítva. A melaningátolt konídiumok esetében csak az IL8 kifejeződésében tapasztaltunk szignifikáns csökkenést (12. ábra).
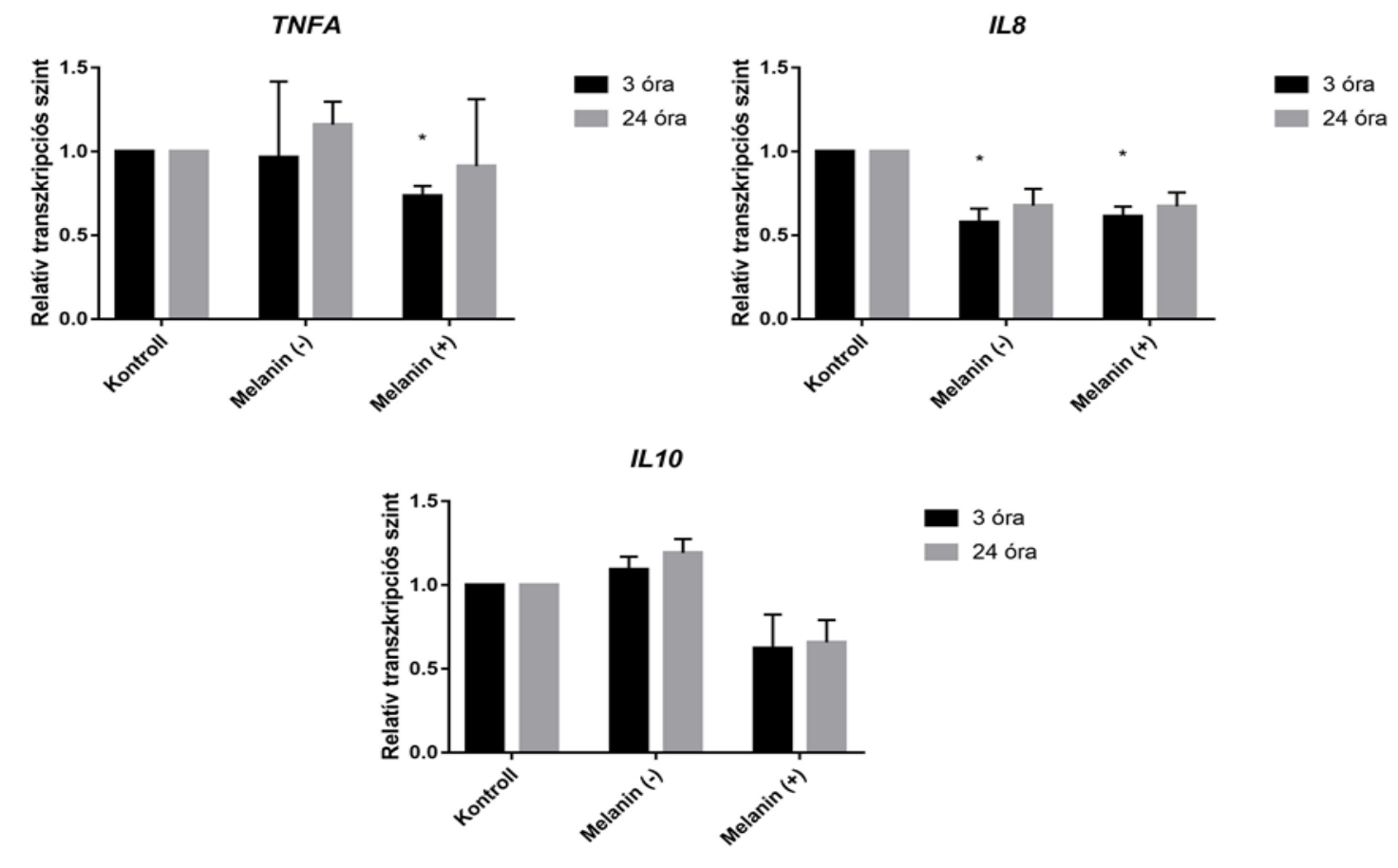

12. ábra: A THP-1 monociták citokint kódoló génjeinek transzkripciós változása $C$. lunata melanizált [melanin (+)] és melanin gátolt [melanin (-)] hőinaktivált konídiumok jelenlétében. A relatív transzkripciós szinteket $\Delta \Delta \mathrm{C}_{\mathrm{T}}\left(2^{-\Delta \Delta \mathrm{Ct}}\right)$ módszerrel határoztuk meg. A statisztikai analízist páros tpróbával végeztük el az azonos időpontban mért sejtes kontrollhoz viszonyítva, $n=3$.

A génexpressziós értékeknek megfelelően a konídiumok jelenlétében nem mutattunk ki jelentős változást a TNFa, IL8, IL6 és IL10 citokinek termelésében a kontroll körülményekhez képest (13. ábra). 

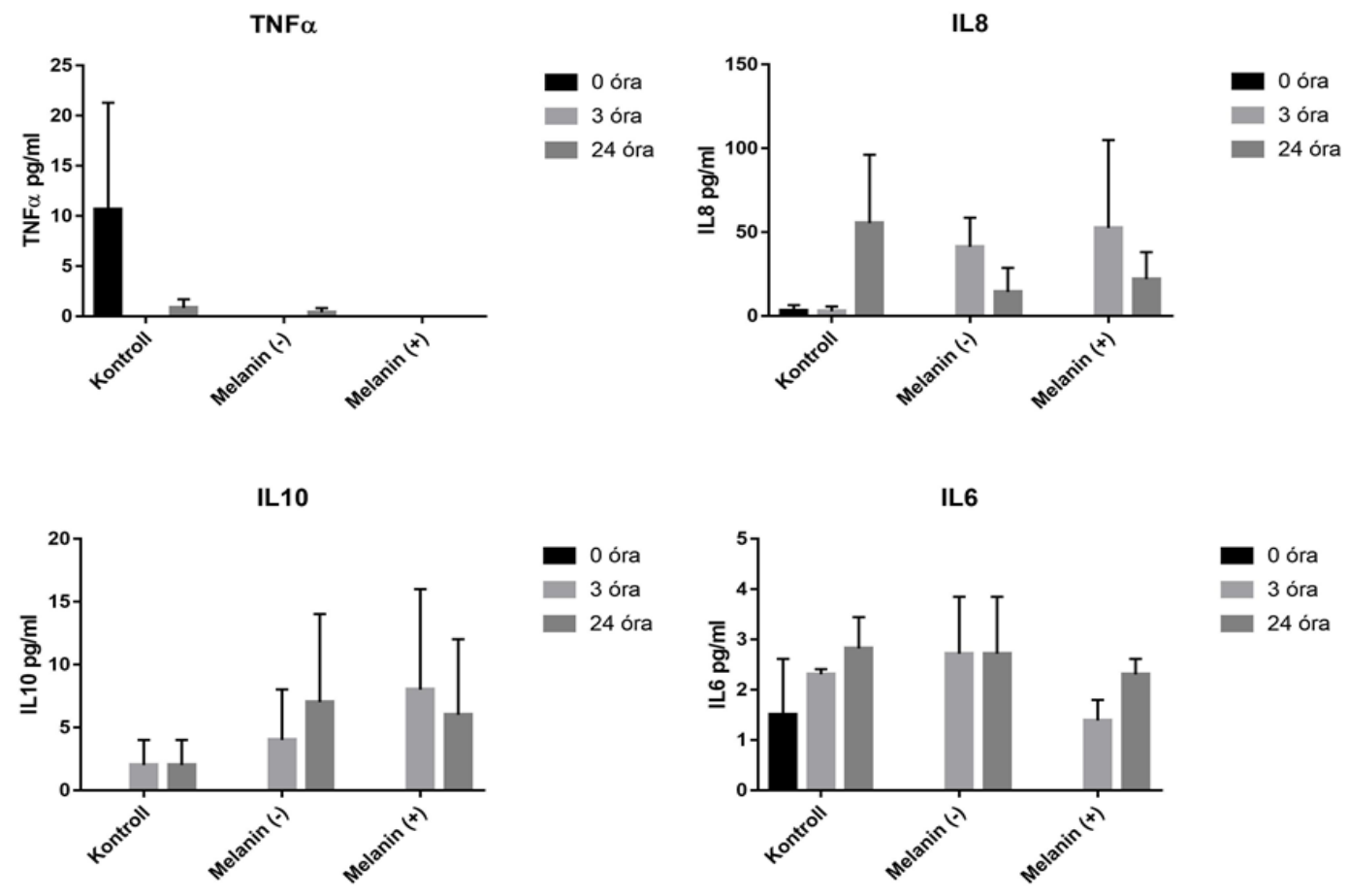

13. ábra: A THP-1 monociták citokin termelése $C$. lunata melanizált [melanin (+)] és melanin gátolt [melanin (-)] hőinaktivált konídiumok jelenlétében. A fehérjék mennyiségét ELISA-val határoztuk $\mathrm{meg}, \mathrm{pg} / \mathrm{ml}$ koncentrációban ábrázoltuk. A statisztikai analízist Kruskal-Wallis teszttel végeztük az azonos időpontban mért sejtes kontrollhoz viszonyítva, $n=3$.

A C. lunata konídiumokkal a monociták elenyésző százaléka került interakcióba, a hőinaktivált konídiumokkal 3 órán át együtt inkubált sejtek esetében is alacsony interakciós százalékot mértünk. Az aktiváció és a citokintermelés hiánya magyarázható a fagocitózis hiányával, azonban a fagocitózis nem minden esetben vált ki citokintermelést. Például az A. fumigatus konídiumok internalizációja ugyan megtörténik, de a szakirodalmi adatok szerint a citokinek génjeinek expressziójában ez a folyamat nem okoz változást (Loeffler és mtsi. 2009). Kontrollként megvizsgáltuk az A. fumigatus élő konídiuminak és hifáinak jelenlétében a TNF-a és IL8 citokineket kódoló gének relatív transzkripciós szintjét, ahol a hifák képesek voltak kiváltani a gének felülszabályozását (14. ábra). A tenyésztés 9. órájában az $A$. fumigatus fiatal hifái, míg a 24. órában elágazó hifái voltak jelen. 


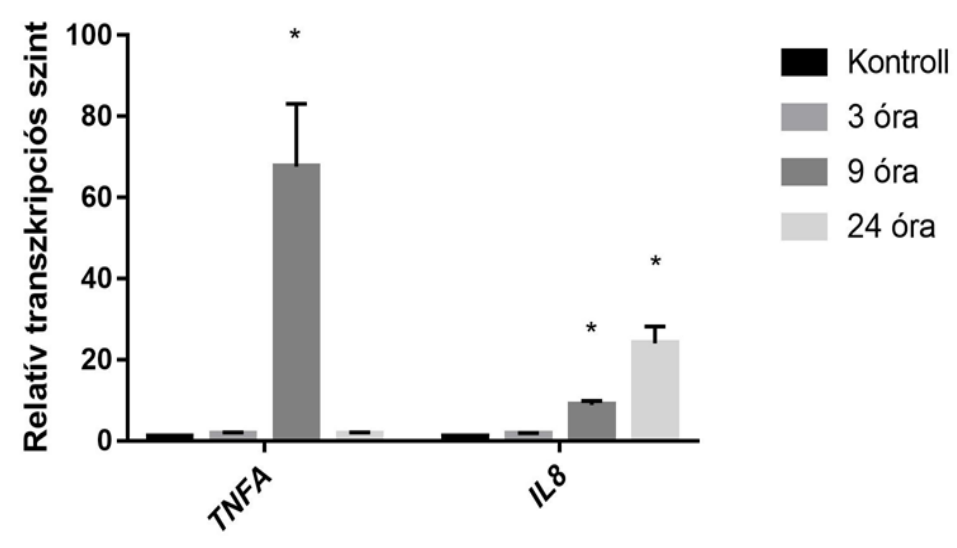

14. ábra: THP-1 monociták TNF $\alpha$ és IL8 citkoineket kódoló génjeinek relatív transzkripciós változása A. fumigatus-sal történő interakció 3., 9. és 24. órájában. A relatív transzkripciós szinteket $\Delta \Delta \mathrm{C}_{\mathrm{T}}\left(2^{-}\right.$ $\Delta \Delta \mathrm{Ct})$ módszerrel határoztuk meg. Kontrollként azonos körülmények között tartott, kezeletlen sejteket használtunk. A statisztikai analízist páros t-próbával végeztük el az azonos időpontban mért sejtes kontrollhoz viszonyítva, $\mathrm{n}=3$.

\subsubsection{A THP-1 sejtek Curvularia hifákra adott válasza}

A THP-1 monociták hifákra adott válaszának vizsgálatánál mikroszkópos vizsgálatot végeztünk a fertőzés 3. és 24. órájában és ugyanezen időpontokban vizsgáltuk a sejtek aktivációját és citokin termelését is. Összehasonlításképpen a kísérletekbe, a $C$. lunata mellett, a $C$. hawaiiensis és a $C$. spicifera egy-egy klinikai izolátumát is bevontuk.

A Curvularia hifák jelenlétében végzett mikroszkópos vizsgálatokból kiderül, hogy a monociták csak a $C$. lunata esetében aggregálódnak a hifa köré 24 óra után. Ez a jelenség a többi törzs esetében nem volt megfigyelhető, valamint a fertőzés korai szakaszában (3 óra után) egyik törzsre sem tapasztaltuk ezt a válaszreakciót (15. ábra).
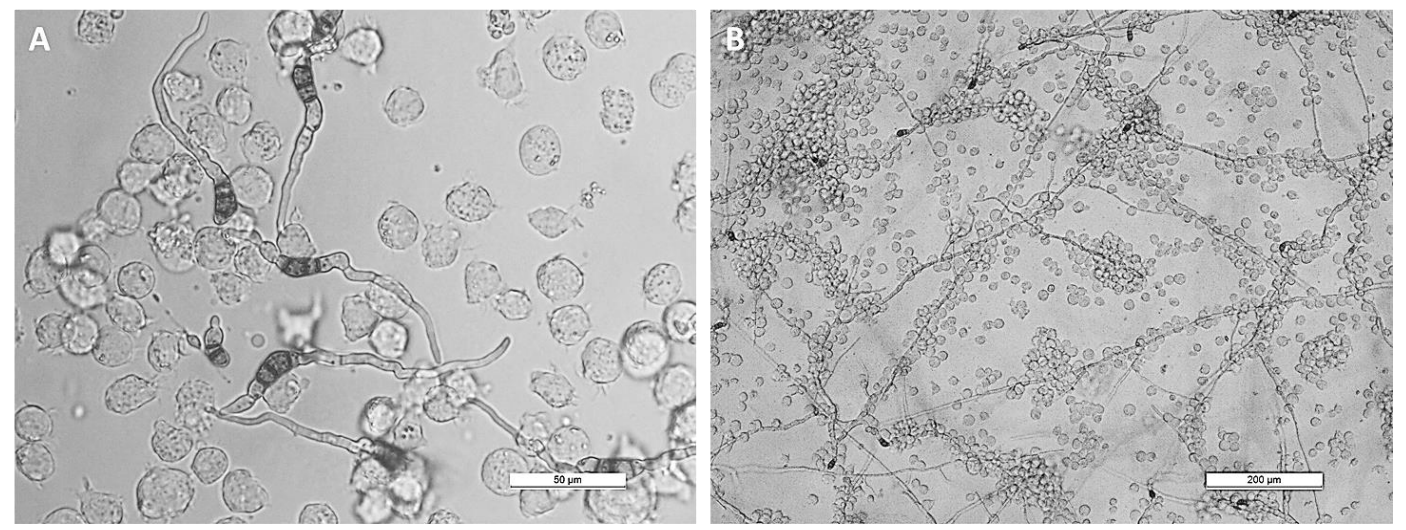

15. ábra: THP-1 monociták és $C$. lunata interakciója 3 óra (A) és 24 óra (B) után. A méretskála az A kép esetében $50 \mu \mathrm{m}$-t, a B kép esetében $200 \mu \mathrm{m}$-t jelöl. 
Mivel a monociták rendelkeznek a patogének eliminálásához szükséges ölési mechanizmusokkal, ezért a sejtek gombákkal szembeni ölési hatékonyságának vizsgálatához az interakciót követően meghatároztuk a gombák életképességét.

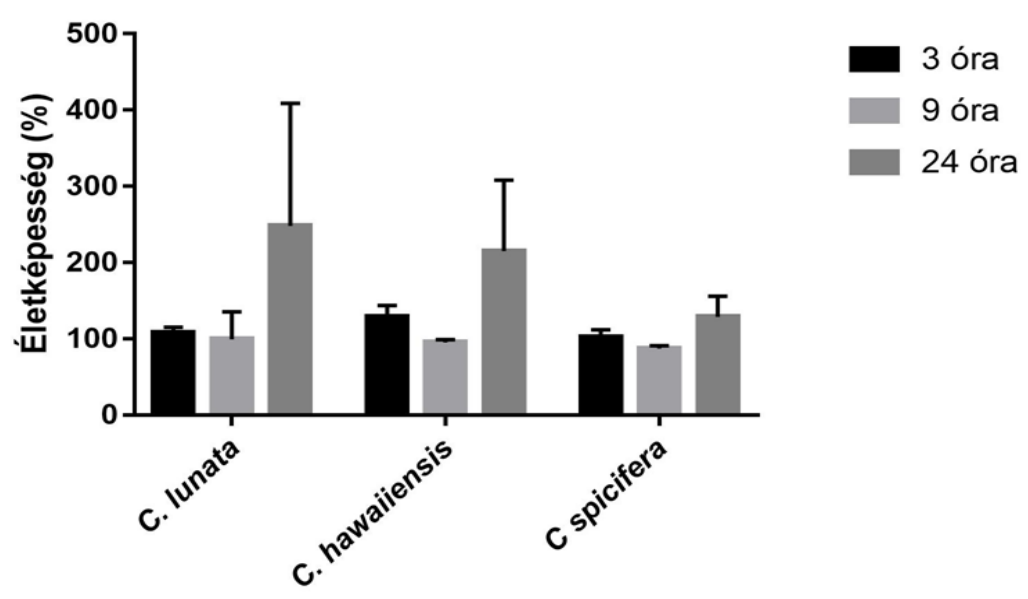

16. ábra: Curvularia izolátumok életképessége THP-1 monocitákkal való interakció után. Az életképességet a kezeletlen gombakontrollhoz viszonyított százalékos értékben fejeztük ki. A vizsgálatot MTT-teszttel végeztük.

A Curvularia izolátumok esetében nem tapasztaltunk csökkenést az életképességben (16. ábra). A kontrollként használt A. fumigatus életképessége 12,9\%-ra csökkent a monocitákkal történt 24 órás interakció után.

Más sejttípusoknál, például makrofágoknál ismert, hogy a gomba körüli sejtcsoportosulás megakadályozza a gomba további szöveti terjedését (Behnsen és mtsi. 2007). C. lunata esetében ugyan megfigyelhető volt a monociták csoportosulása, azonban a gomba sok esetben túlnőtte az aggregáció helyét (15/B. ábra). A magasabb életképesség ebben az esetben feltételezhetően a gyorsabb növekedési ütemmel magyarázható.

Akárcsak a konídiumok esetében, a hifákra adott válasznál is megvizsgáltuk a monocita sejtek aktivációját. Ebben az esetben több gént is bevontunk a vizsgálatokba.

A konídiumoknál is vizsgált $C C R 1$ és $C C R 2$ gének mellett a $C C R 5$ gén kifejeződését is vizsgáltuk (17. ábra), amely a CCRl-hez hasonóan, a THP-1 aktiváció során nem kerül gátlás alá (Phillips et al. 2005). 


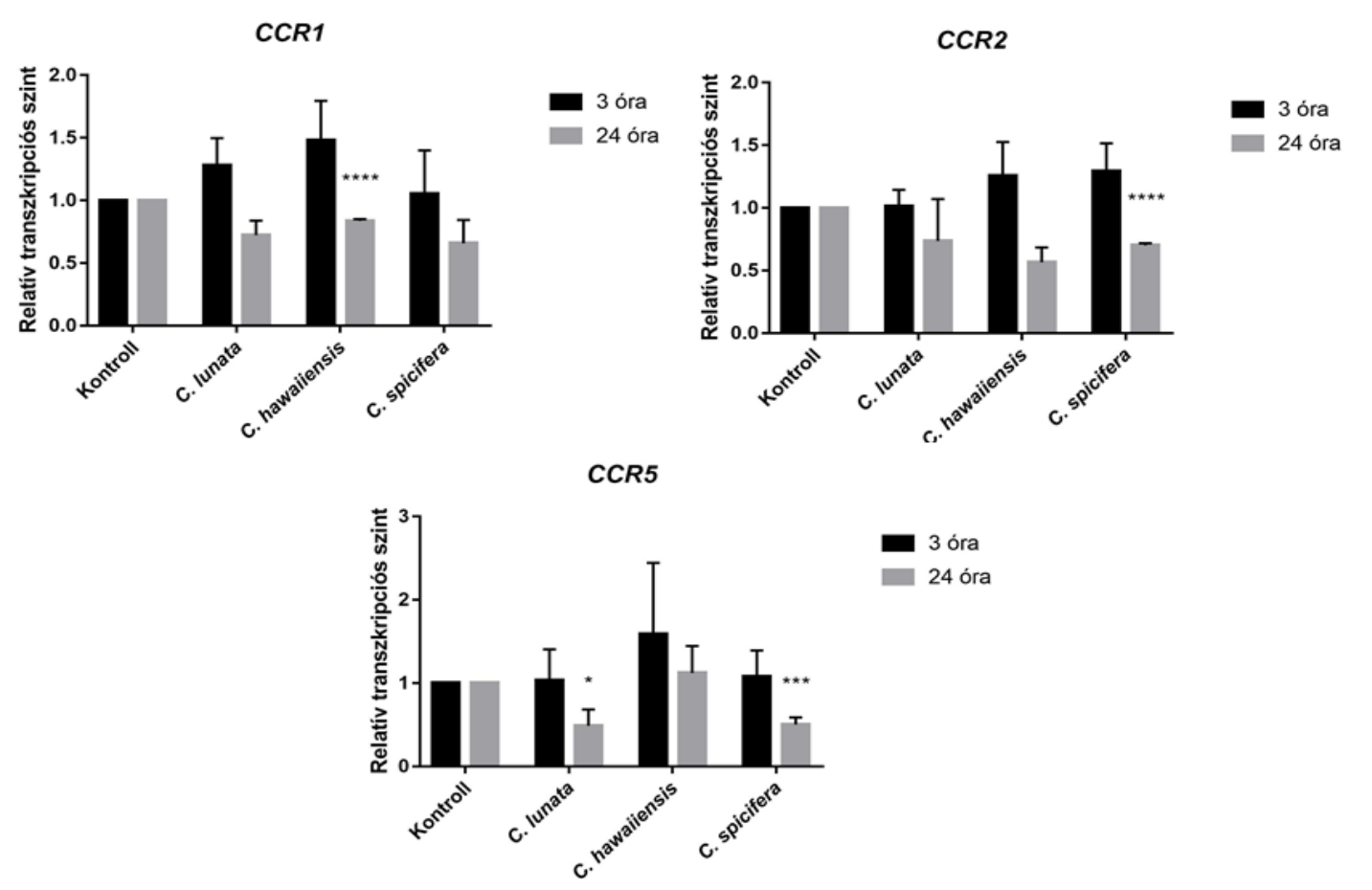

17. ábra: A THP-1 monociták aktivációját jelző $C C R$ gének relatív transzkripciós szintje. A relatív transzkripciós szinteket $\Delta \Delta \mathrm{C}_{\mathrm{T}}\left(2^{-\Delta \Delta \mathrm{Ct}}\right)$ módszerrel határoztuk meg. Kontrollként azonos körülmények között tartott, kezeletlen sejteket használtunk. A statisztikai analízist páros t-próbával végeztük el az azonos időpontban mért sejtes kontrollhoz viszonyítva, $\mathrm{n}=3$.

A CCR2 gén alulszabályozása a C. hawaiiensis és $C$. spicifera esetében 24 óra elteltével megfigyelhetö, azonban a CCRl és CCR5 gének relatív transzkripciós szintjében is csökkenést tapasztaltunk, amely mintázat nem jellemző a THP-1 aktiváció során (17. ábra).

A CD11 molekulák az endotél sejtekkel való kapcsolat kialakításában szerepet játszó integrinek, amelyek mennyisége az aktiváció során megemelkedik. A CD11a, CD11b és CD11c molekulák mennyiségéből következtetni lehet a differenciáció irányára is (Ammon et al. 2000) Ezen molekulákat kódoló ITGAL, ITGAM és ITGAX gének relatív transzkripciós szintje nem mutatott emelkedést a gombák jelenlétében (18. ábra). Az eredményekből arra következtethetünk, hogy a Curvularia izolátumok hifái önmagukban nem indítják el a monocita aktiváció és differenciáció folyamatát. 

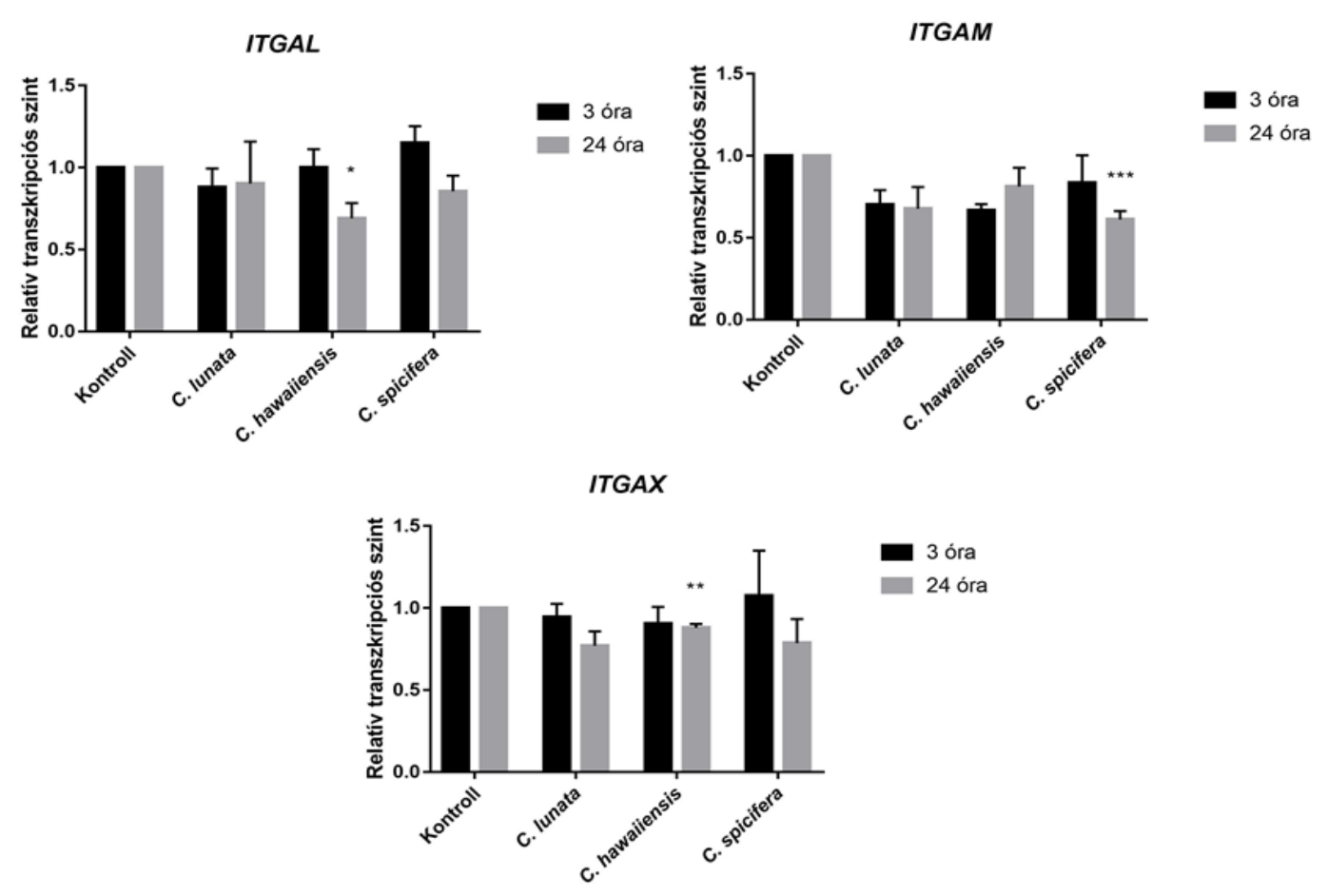

18. ábra: THP-1 monociták adhézióhoz köthető génjeinek relatív transzkripciós szintjei. A relatív transzkripciós szinteket $\Delta \Delta \mathrm{C}_{\mathrm{T}}\left(2^{-\Delta \Delta \mathrm{Ct}}\right)$ módszerrel határoztuk meg. Kontrollként azonos körülmények között tartott, kezeletlen sejteket használtunk. A statisztikai analízist páros t-próbával végeztük el az azonos időpontban mért sejtes kontrollhoz viszonyítva, $\mathrm{n}=3$.

Ezt az eredményt támasztja alá a konídiumok jelelétében is vizsgált $H L A D R A$ gén transzkripciós mintázata is. A C. lunata esetében 3 óra után ugyan kismértékű transzkripciós emelkedést látható, 24 óra után erőteljes alulszabályozás figyelhető meg. A 24 óra utáni transzkripciós gátlás a $C$. hawaiiensis és $C$. spicifera jelenlétében is megmutatkozik (19. ábra). A monociták HLA-DR expressziójának csökkenése több tanulmány szerint is protektív immunválasz (Palojarvi és mtsi. 2013) és az immunszuppresszió kialakulásához vezet, amely a nozokomiális fertőzésekkel is összefüggésbe hozható ( Drewry és mtsi. 2016, Manzoli és mtsi. 2016, Boeddha és mtsi. 2018).

A gén által kódolt MHCII molekula részt vesz az antigén prezentációban (Busch és mtsi. 2005). A mikroszkópos vizsgálatoknál tapasztaltuk, hogy a monociták és a gombahifák között 3 óra után nem alakul ki sejt-sejt kapcsolat (15/A. ábra). A HLADRA 3 óra utáni transzkripciós emelkedése nem utal antigén prezentációra. A C. lunata esetében 24 óra elteltével a sejtek a hifákhoz tapadnak (15/B. ábra), azonban ezen időpontban a HLADRA génben alulszabályozás látszik, amely az antigén prezentáció hiányára utalhat (19. ábra). 
HLADRA

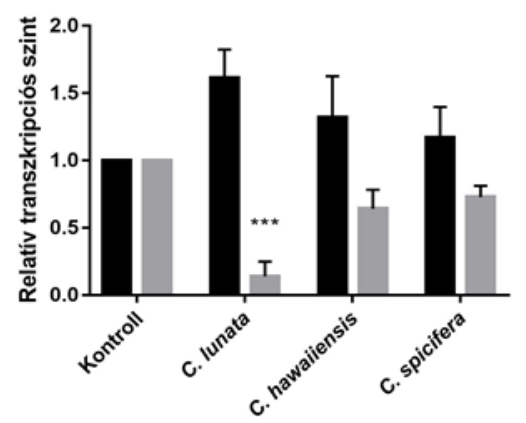

NLRC3

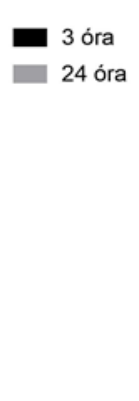

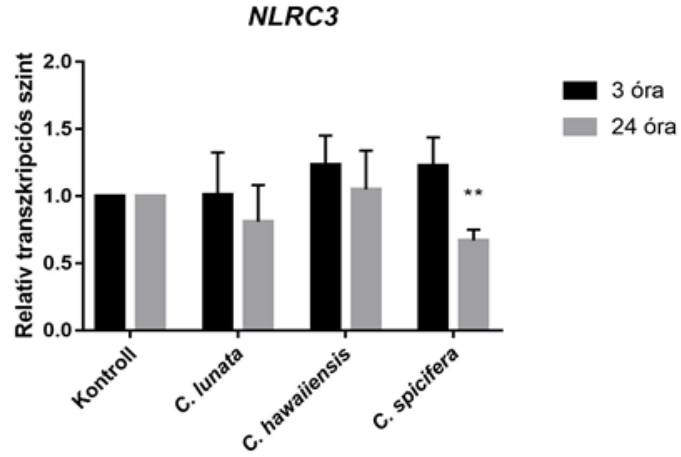

19. ábra: THP-1 monociták HLADRA és $N L R C 3$ génjeinek relatív transzkripciós szintjei. A relatív transzkripciós szinteket $\Delta \Delta \mathrm{C}_{\mathrm{T}}\left(2^{-\Delta \Delta \mathrm{Ct}}\right)$ módszerrel határoztuk meg. Kontrollként azonos körülmények között tartott, kezeletlen sejteket használtunk. A statisztikai analízist páros t-próbával végeztük el az azonos időpontban mért sejtes kontrollhoz viszonyítva, $\mathrm{n}=3$.

Az NLRC3 molekula az immunválasz negatív szabályozója, amely az NLRP3 inflammaszóma összeszerelődés gátlásával megakadályozza az IL1 $\beta$ felszabadulást (Gultekin és mtsi. 2015). A molekulát kódoló gén relatív transzkripciójában nem mértünk emelkedést a Curvularia törzsek jelenlétében, $C$. spicifera esetében 24 óra elteltével szignifikáns csökkenés volt megfigyelhető (19. ábra). Feltételezhető, hogy ez a molekula nem vesz részt a monociták válaszának regulálásában a Curvularia fertőzések esetében.

A monociták citokin válaszát génexpressziós és fehérje szinten is vizsgáltuk. A gyulladásos citokinek közül a TNFA, IL8, IL6 és IL1B gének relatív expressziós mintázatát vizsgáltuk a gombák jelenlétében. A TNF $\alpha$-t kódoló gén expressziójában mindhárom vizsgált törzs jelenlétében emelkedést tapasztaltunk 24 óra elteltével, a $C$. spicifera és $C$. hawaiiensis már 3 óra után relatív transzkripciós növekedést okozott a sejtekben. Az IL8 génjének vizsgálatakor kismértékü, de statisztikailag nem szignifikáns emelkedést mértünk a vizsgált Curvularia törzsek általi 24 órás indukció hatására (20. ábra). Az IL6 citokint kódoló gén esetében nem tapasztaltunk transzkripciós változást. Az IL1 $\beta$ génjének alulszabályozását mértuik 3 és 24 órás $C$. lunata-val valamint 3 óra után $C$. hawaiiensis-szel való interakció után, a C. spicifera nem okozott szignifikáns változást a transzkripcióban. Az IL10 antiinflammatorikus citokint kódoló gén vizsgálatakor erősebb transzkripciót mértünk mindhárom gombatörzs hatására 24 óra elteltével (20. ábra). 

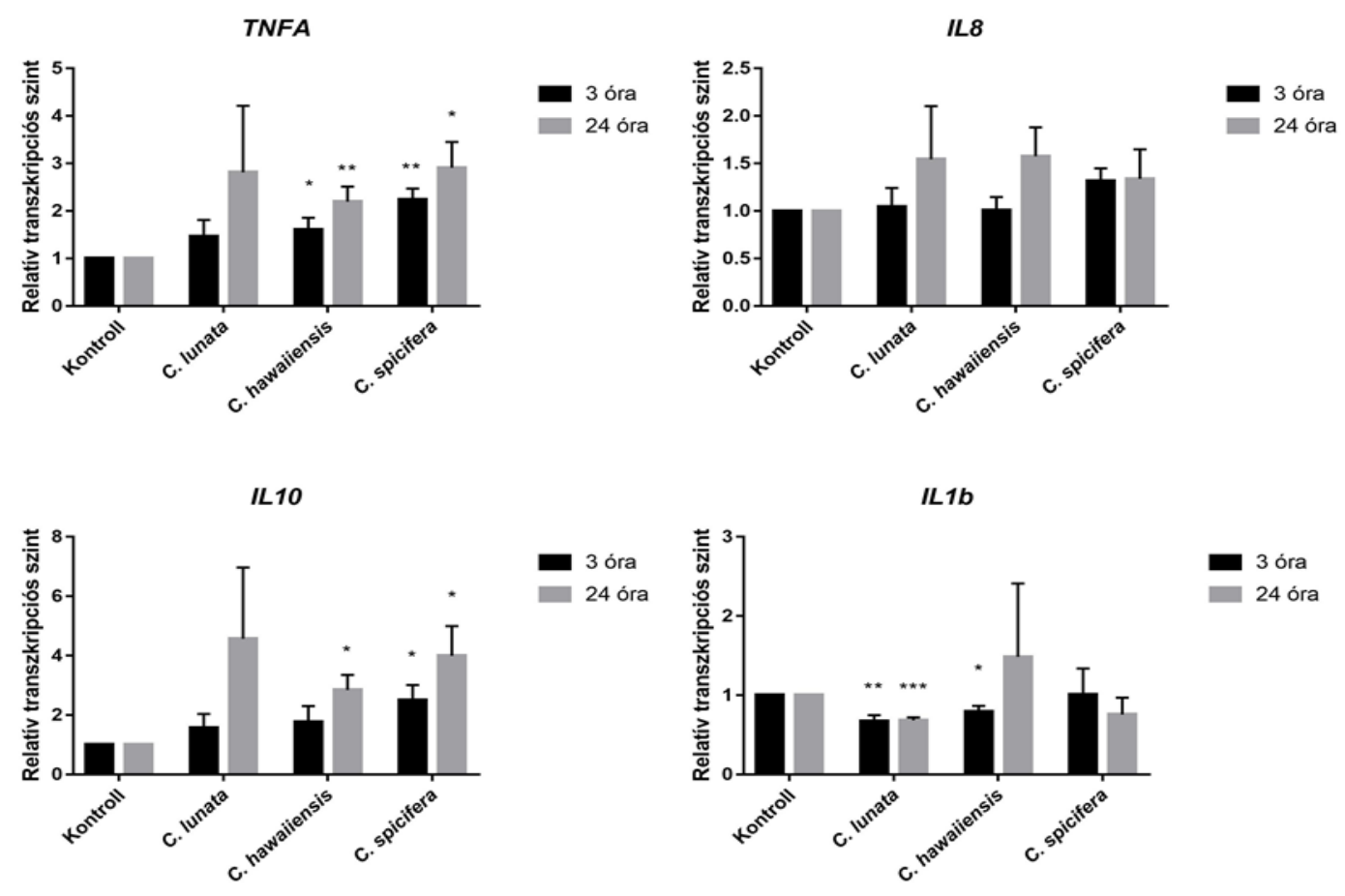

20. ábra: A THP-1 monociták citokineket kódoló génjeinek relatív transzkripciós szintjei. A relatív transzkripciós szinteket $\Delta \Delta \mathrm{C}_{\mathrm{T}}\left(2^{-\Delta \Delta \mathrm{Ct}}\right)$ módszerrel határoztuk meg. Kontrollként azonos körülmények között tartott, kezeletlen sejteket használtunk. A statisztikai analízist páros t-próbával végeztük el az azonos időpontban mért sejtes kontrollhoz viszonyítva, $\mathrm{n}=3$.

Kontrollként az LPS-re adott válasz esetében is megvizsgáltuk a citokineket kódoló gének kifejeződését. Erőteljes TNFA, IL8, IL6, IL10 és IL1B kifejeződést mértünk már 3 óra elteltével. 24 óra elteltével ugyan a relatív transzkripciós szint visszaesett, de még mindig emelkedett értékeket mutatott (21. ábra).
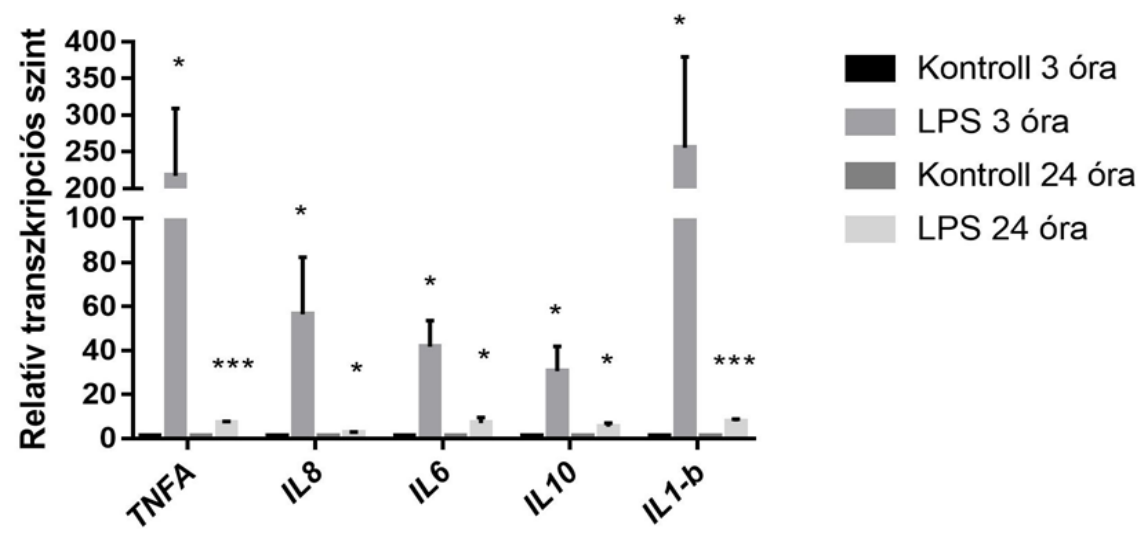

21. ábra: THP-1 monociták citokin kódoló génjeinek relatív transzkripciós változása LPS indukció hatására 3 és 24 óra után. A relatív transzkripciós szinteket $\Delta \Delta \mathrm{C}_{\mathrm{T}}\left(2^{-\Delta \Delta \mathrm{Ct}}\right)$ módszerrel határoztuk meg. Kontrollként azonos körülmények között tartott, kezeletlen sejteket használtunk. A statisztikai analízist páros t-próbával végeztük el az azonos időpontban mért sejtes kontrollhoz viszonyítva, $\mathrm{n}=$ 3. 
A citokinek mennyiségének fehérjeszintü meghatározásánál nem tapasztaltunk IL6 termelést a Curvularia izolátumokkal való interakció után, a $C$. hawaiiensis és $C$. spicifera csírázó konídiumainak és hifáinak jelenlétében a kontroll sejtekhez hasonló citokin mennyiségeket mértünk TNFa, IL8 és IL10 esetében is (22. ábra).
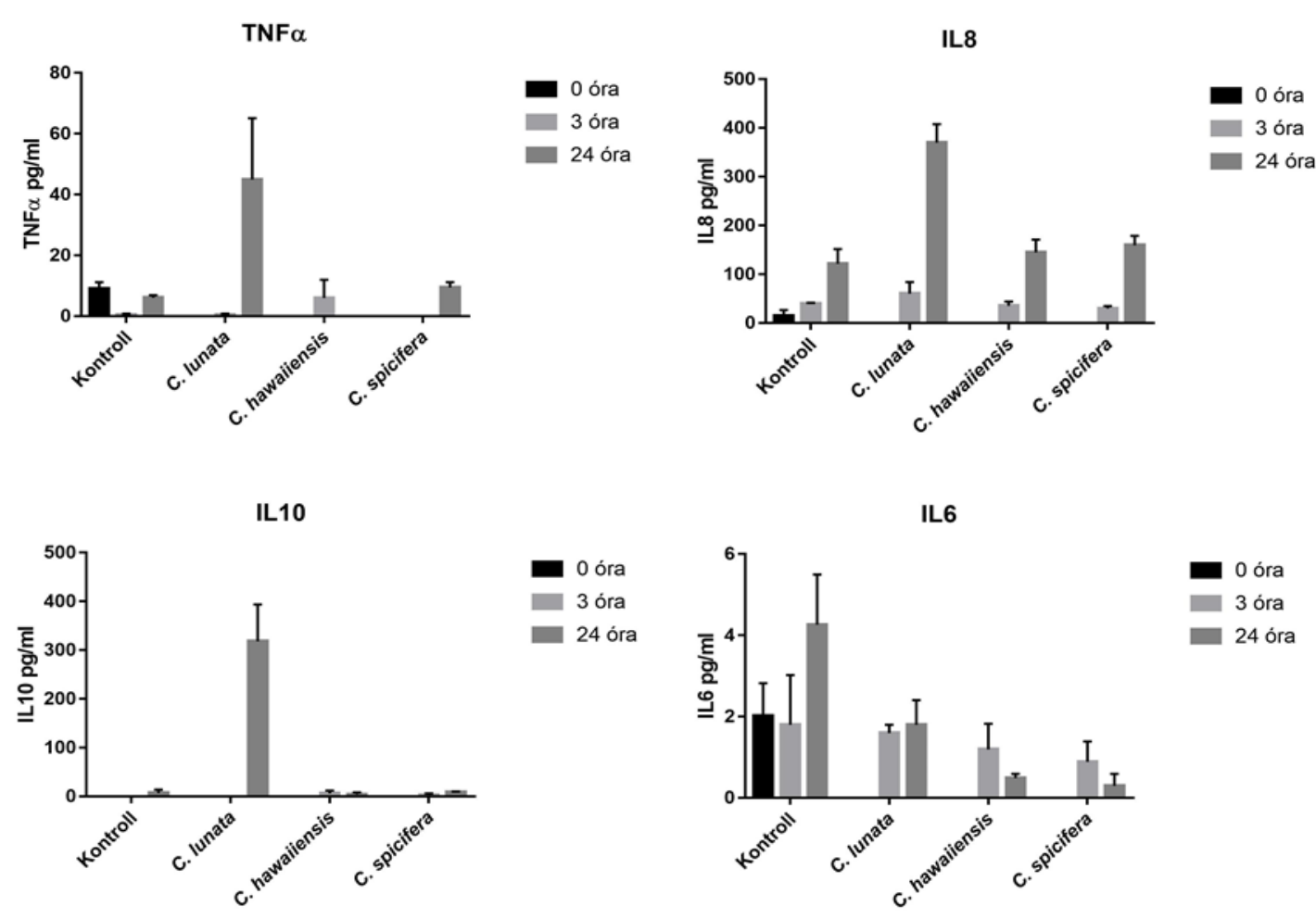

22. ábra: THP-1 monociták citokin termelése Curvularia törzsekkel való interakció 3. és 24. órájában. A fehérjék mennyiségét ELISA-val határoztuk meg, pg/ml koncentrációban ábrázoltuk. A statisztikai analízist Kruskal-Wallis teszttel végeztük az azonos időpontban mért sejtes kontrollhoz viszonyítva, $\mathrm{n}=3$.

A C. lunata 24 óra elteltével kis mennyiségü TNFa termelődést (45 pg/ml) indukált, valamint az IL8 (340 pg/ml) és az IL10 (318 pg/ml) termelése jelentősen megemelkedett (22. ábra). Az A. fumigatus-szal indukált kontroll sejtek esetében hasonló mennyiségű IL8 (376 $\mathrm{pg} / \mathrm{ml})$ termelödését mutattunk ki, viszont csak kis mennyiségü IL10 (43 pg/ml) termelést detektáltunk. Az IL8 termelés ebben az esetben egyéb kutatások által is alátámasztott (Loeffler és mtsi. 2009, Cortez és mtsi. 2006). Az LPS indukció után 3 órával 377 pg/ml IL8 és 10 pg/ml IL10 termelést mértünk, míg 24 órával 567 pg/ml IL8 és 5 pg/ml IL10 mennyiséget határoztunk meg (23. ábra). 

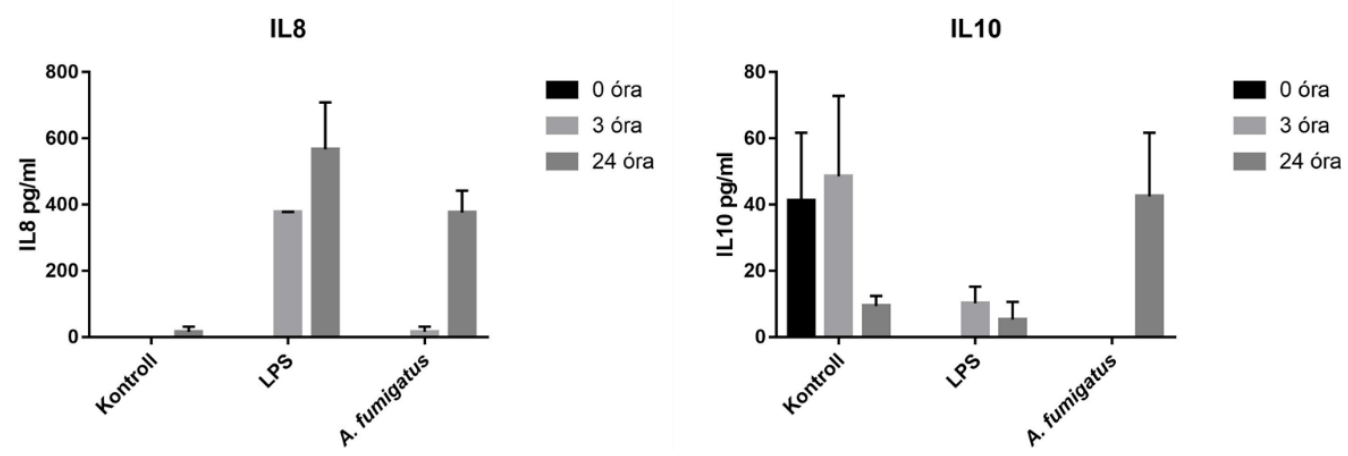

23. ábra: A monociták IL8 és IL10 termelése LPS és A. fumigatus $(\mathrm{E}: \mathrm{T}=20: 1)$ indukció hatására 3 és 24 óra után. A fehérjék mennyiségét ELISA-val határoztuk meg, pg/ml koncentrációban ábrázoltuk. A statisztikai analízist Kruskal-Wallis teszttel végeztük az azonos időpontban mért sejtes kontrollhoz viszonyítva, $\mathrm{n}=2$.

A proinflammatorikus citokinek fontos szerepet játszanak a gombák elleni immunválasz kialakításában (Antachopoulos és Roilides 2005), a Curvularia izolátumok jelenlétében tapasztalt kis mennyiségü gyulladásos citokin termelés ebből a szempontból meglepö jelenség, amelyet a $C$. lunata esetében tapasztalt antiinflammatorikus IL10 termelés magyarázhat, hiszen ez a citokin gátolja a proinflammatorikus citkoinek termelését (de Waal Malefyt és mtsi. 1991, Couper és mtsi. 2008, Ouyang és mtsi. 2011). Az IL10 rendellenesen magas szintje a szérumban A. fumigatus fertőzésre való hajlamosító tényező (Romani 2004), a citokin hiánya pedig a $C$. albicans és a $H$. capsulatum gyorsabb eliminációját eredményezte (Romani és mtsi. 1994, Deepe és Gibbons 2003). A kiváltott magas IL10 koncentráció összefügghet azzal, hogy a Curvularia fajok, föleg a C lunata immunokompetens egyénekben is krónikus fertőzéseket okozhat, amelyek többsége egyben allergiás megbetegedés is (Krizsán és mtsi. 2015).

Az IL10 gátolni képes az IL8 termelödését is, azonban az IL10 termelés ellenére a $C$. lunata hifáinak jelenlétében 24 óra után magas IL8 szintet is kimutattunk. Ez a citokin a neutrofil granulociták fő kemoattraktánsa (Hoffmann és mtsi. 2002), ami azt sugallja, hogy ezeknek a sejteknek fontos szerepe van a gomba elleni védekezésben.

A $C$. hawaiiensis és $C$. spicifera esetében mért transzkripciós emelkedések ellenére egyik vizsgált citokin termelését sem tudtuk fehérje szinten kimutatni. A TNFa szekréció szabályozása transzkripciós és transzlációs szinten is megvalósul (Spriggs és mtsi. 1992, Parameswaran és Patial 2010), ezen citokin esetében valószínúleg a fehérje termelésére transzlációs gátlás hat. Az IL10 és IL8 citokinek megjelenése azonban elsősorban 
transzkripciós szabályozás alatt áll (Le és mtsi. 1997, Roebuck 1999), a szekréció hiányát valószínủleg a transzlációs gátlás nem magyarázza.

A közeli rokon gombákra adott eltérő immunválasz más nemzetségeken belül is megfigyelhető. A monociták az Aspergillus nemzetség különböző tagjaival szemben eltérő IL6 és TNFa választ adtak (Warris és mtsi. 2005), de a Candida fajok esetében is írtak le különbségeket az immusejtek általi felismerés és citokintermelés tekintetében (Netea és mtsi. 2015, Toth és mtsi. 2017a).

Az ebben a fejezetben bemutatott eredményeket a következő publikáció tartalmazza: Tóth és munkatársai (2017b).

\subsection{Makrofágok válasza Curvularia izolátumokra}

A makrofággá érlelt THP-1 sejtek interakcióját is megvizsgáltuk a Curvularia izolátumokkal. A 3 és 24 órás vizsgálatoknál a $C$. lunata mellett ebben az esetben is bevontuk a $C$. hawaiiensis és $C$. spicifera egy-egy klinikai izolátumát.

Mivel a makrofágok elsődleges feladata A. fumigatus-szal szemben a spórák eliminálása (Marr és mtsi. 2001, Philippe és mtsi. 2003), a sejtek C. lunata konídiumokat fagocitáló képességét vizsgáltuk. A vizsgálatot 1 és 2 óra ko-inkubációt követően végeztük el, élő konídiumok jelenlétében (24. ábra). Két óra elteltével már csírázó konídiumok vannak jelen.

Egy óra elteltével a sejtek 4,3( $\pm 1,5) \%$-a mutatott interakciót a $C$. lunata konídiumokkal 20:1 (E:T) arány esetén. Habár ez az érték elmarad az A. fumigatus-sal 1:2 (E:T) arányban fertőzött sejteknél tapasztalt 23( \pm 1$) \%$-os értéktől, azt érdemes megjegyezni, hogy a C. lunata konídiumok 30,9( $\pm 1,9) \%$-át ismerték fel a sejtek ebben az időpontban (24/I. ábra). Két óra után a sejtek 6,3( $\pm 1,8) \%$-a mutatott pozitív eredményt az interakcióra nézve $(E: T=20: 1)$. Ebben az időpontban a konídiumok $43( \pm 2,2) \%$-át ismerték fel a makrofágok. A C. lunata esetben mért pozitív események többsége tényleges internalizációt is. A. fumigatus esetében a monocitákhoz hasonlóan itt is megvizsgáltuk 3 óra elteltével a fagocitáló sejtek arányát. 1:2 (E:T) fertőzési aránynál a sejtek 46,2( $\pm 0,24) \%$-a fagocitált (24/II. ábra), míg 20:1 (E:T)

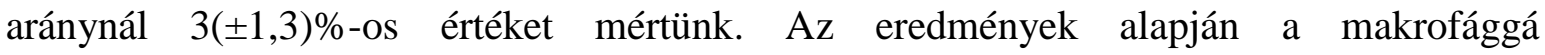
differenciáltatott THP-1 sejtek képesek felismerni és fagocitálni a $C$. lunata konídiumokat. 
I.)

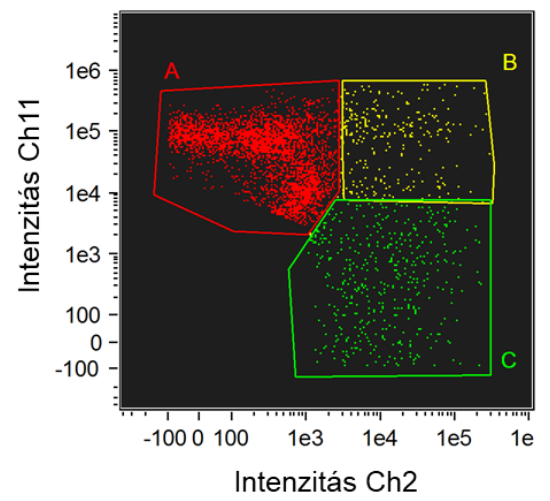

II.)
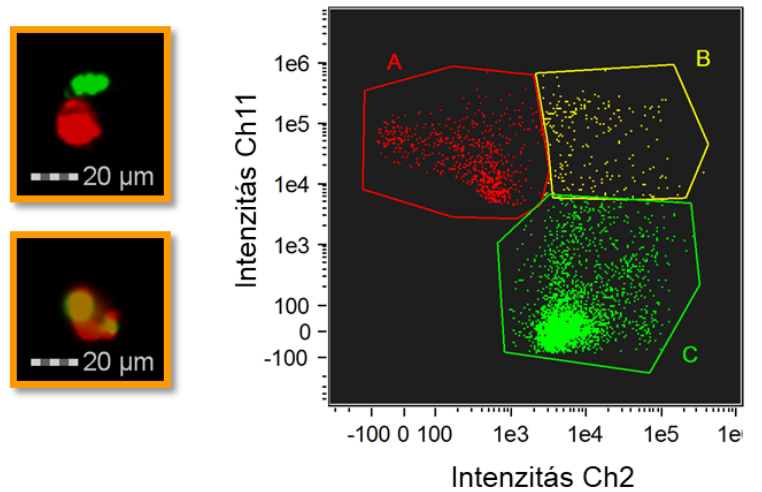
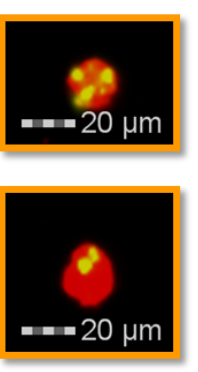

24. ábra: A THP-1 makrofágok fagocitáló képessége I.) C. lunata (E:T = 20:1) és II.) A. fumigatus $(\mathrm{E}: \mathrm{T}=1: 2)$ konídiumokkal szemben 1 óra elteltével. Az ábrákon az A (piros) populáció a monocitákat, a B (sárga) a konídiumokkal interakcióban lévő sejteket, míg a C (zöld) a konídiumokat jelenti. A tengelyek a piros (Ch11) és zöld (Ch2) fluoreszcencia intenzitást jelölik. A sárga keretbe foglalt fluoreszcens felvételek a konídiumok és sejtek interakcióit mutatja, ahol zöld színnel a konídium, pirossal a makrofág látható.

$\mathrm{Az}$ interakció 3. és 24. órájában mikroszkópos vizsgálatot végeztünk (25. ábra). A sejtek hifa körüli aggregációját egyik törzsnél sem tapasztaltuk, azonban itt is megfigyelhetőek voltak a konídiumokhoz kapcsolódó sejtek.

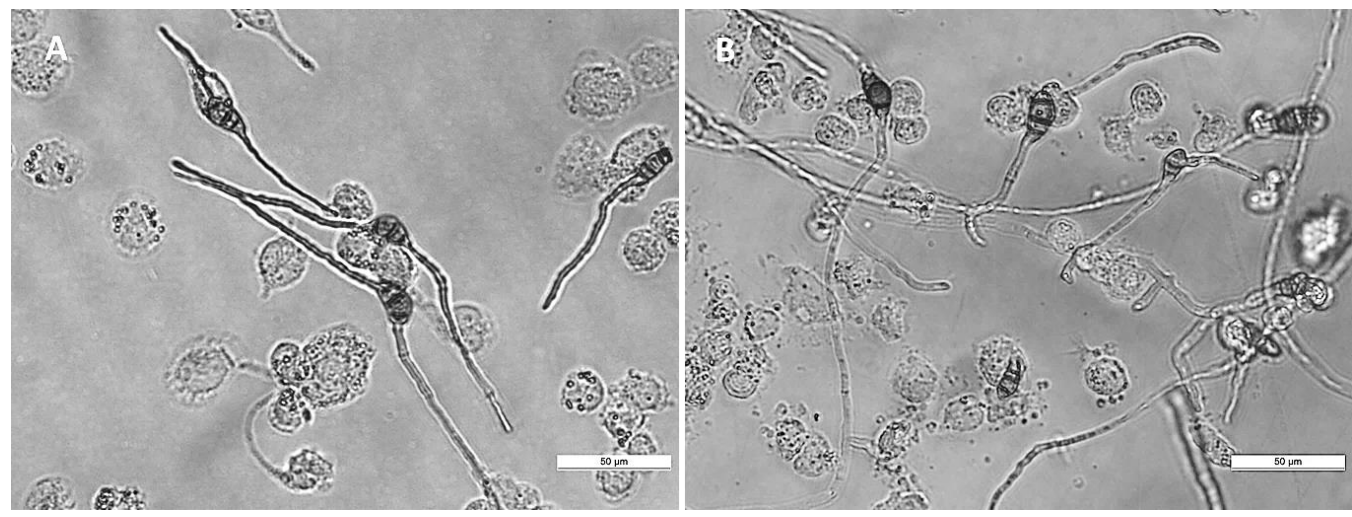

25. ábra: A THP-1 makrofágok és a $C$. lunata interakciója 3 (A) és 24 (B) óra után. A képeken a méretskála $50 \mu \mathrm{m}$-t jelöl.

24 óra ko-inkubáció után mértük az izolátumok életképességét (26. ábra), amelyből kiderül, hogy a THP-1 makrofágok nem voltak képesek a gombák hatékony ölésére. Irodalmi adatok alapján az A. fumigatus fiatal hifái indukálják a makrofágok NADPH oxidáz általi ROS, valamint citokin termelését (Gersuk és mtsi. 2006), a hifák károsítását azonban főleg a neutrofil granulociták végzik (Rosowski és mtsi. 2018). 


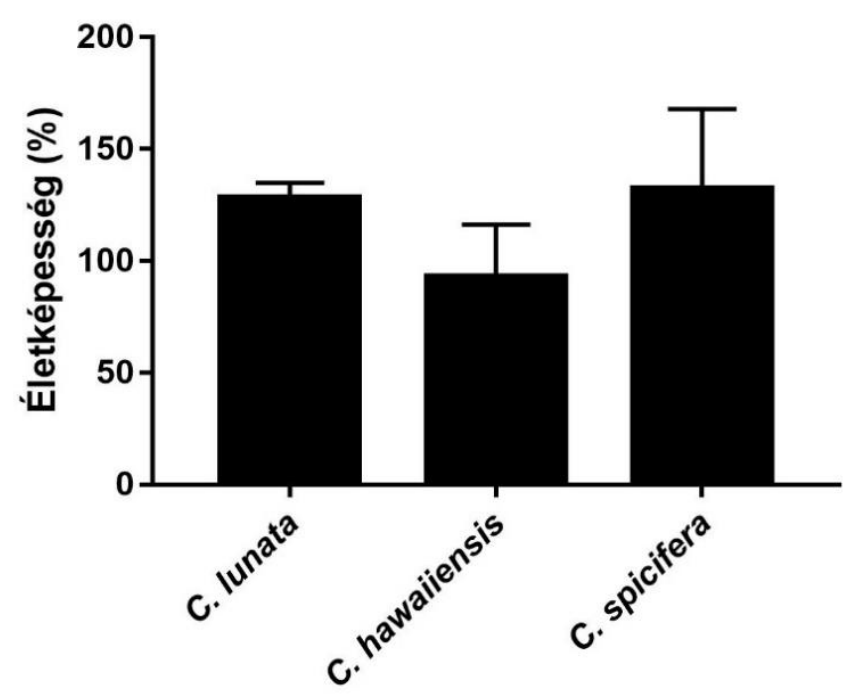

26. ábra: A Curvularia izolátumok életképessége a THP-1 makrofágokkal való 24 órás interakciót követően, az azonos körülmények között nevelt gomba kontrollhoz viszonyított százalékos értékben. Az életképességet MTT-teszttel határoztuk meg.

A THP-1 makrofágok az eredmények alapján a $C$. lunata konídiumait felismerik és fagocitálják, ennek ellenére a gomba életképessége a sejtek nélkül nevelt törzshöz képest nem csökkent. Valószínüleg az internalizált konídiumok csírázását jelentősen nem gátolták a sejtek. A $C$. hawaiiensis és $C$. spicifera esetében sem tapasztaltuk az életképesség csökkenését. A hifák nem váltották ki a THP-1 makrofágok aggregációját.

\subsection{Neutrofil granulociták válasza Curvularia lunata-ra}

A primer neutrofil granulociták tisztaságát és életképességét az izolálás után ellenőriztük: minden esetben minimum 95\%-os tisztaságot (a kontamináló sejteket Wright festés alapján eritrocitaként azonosítottuk) és 97\%-os életképességet értünk el.

A kísérletekben vizsgáltuk a neutrofilek felismerési mechanizmusát, ROS termelését, NET képzését és ölési hatékonyságát $C$. lunata-val szemben. Kontrollként A. fumigatus-t használtunk.

A sejtek felismerési mechanizmusát a különböző körülmények között felszabaduló MPO mennyiségének meghatározásával vizsgáltuk (27. ábra). Az enzim extracelluláris megjelenése jelzi a sejtek aktivációját (van der Veen és mtsi. 2009). 


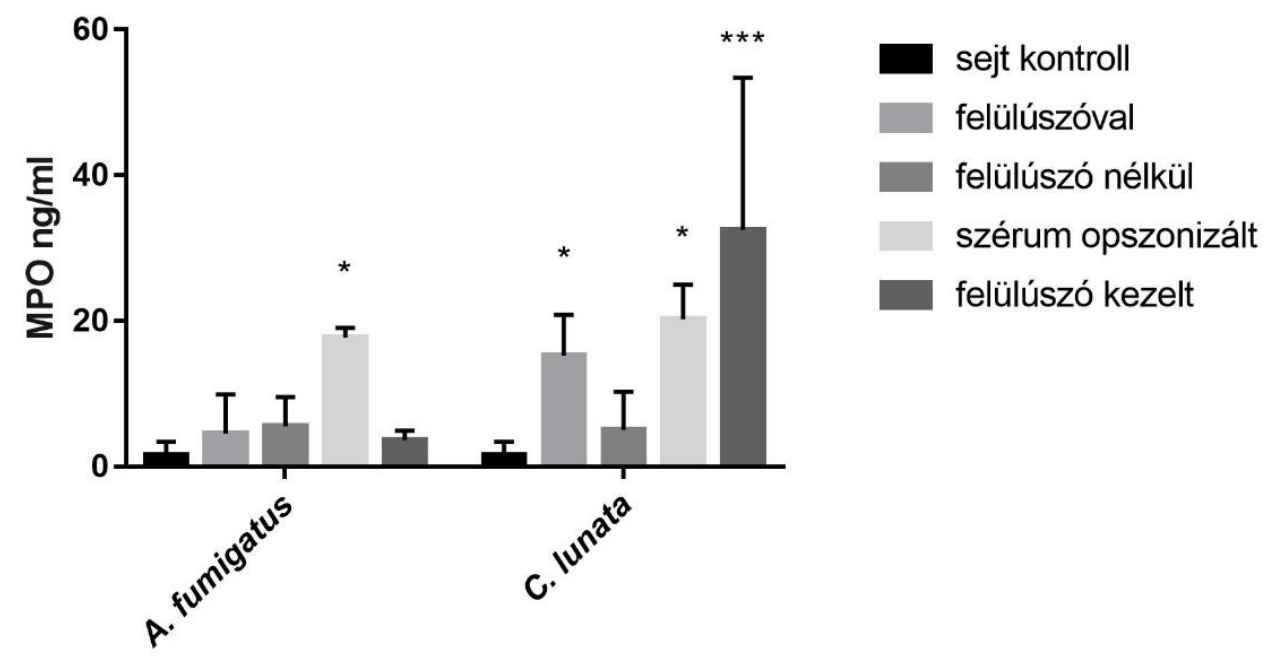

27. ábra: A neutrofil granulociták által kibocsátott MPO mennyisége A. fumigatus és $C$. lunata jelenlétében, különböző körülmények között. Kontrollként az azonos körülmények között nevelt, kezeletlen sejteket használtuk. Felülúszóval: a neutrofil granulocitákat közvetlenül adtuk a csírázó konídiumokhoz; felülúszó nélkül: a neutrofilek hozzáadása előtt a fiatal hifákat mKRPG pufferrel mostuk; szérum opszonizált: a gombákat a csírázás utolsó órájában megfelelő donorból származó szérummal opszonizáltuk; felülúszó kezelt: a neutrofil sejtekhez a gombák sejtmentes csíráztatási felülúszóját adtuk. $\mathrm{n}=12$; a statisztikai analízist kétszempontos ANOVA módszerrel végeztük.

Míg az A. fumigatus a szakirodalmi adatoknak megfelelően csak szérum opszonizáció után aktiválta a sejteket (Gazendam és mtsi. 2016), a C. lunata csíráztatási felülúszója és az opszonizált gomba jelenlétében is mértünk az extracelluláris MPO szintjében emelkedést. Ebből arra következtethetünk, hogy a gomba felismerése az A. fumigatus-hoz hasonlóan történik, valamint, hogy a C. lunata által termelt valamely szolubilis faktor képes indukálni a neutrofil aktivációt.

A MPO feladata elsősorban az oxidatív burst során termelődő $\mathrm{H}_{2} \mathrm{O}_{2} \mathrm{HOCl}$-é alakítása (3.8.3. fejezet), amely biztosítja a hatékony ölést. Az interakció során mértük a termelődő $\mathrm{H}_{2} \mathrm{O}_{2}$ mennyiségét. Azt tapasztaltuk, hogy az A. fumigatus-hoz hasonlóan a $C$. lunata is csak szérum opszonizáció után képes indukálni a ROS felszabadulást, azonban az interakció 60. percében (az A. fumigatus-sal ellentétben) az majdnem teljesen eltűnik (28. ábra). 


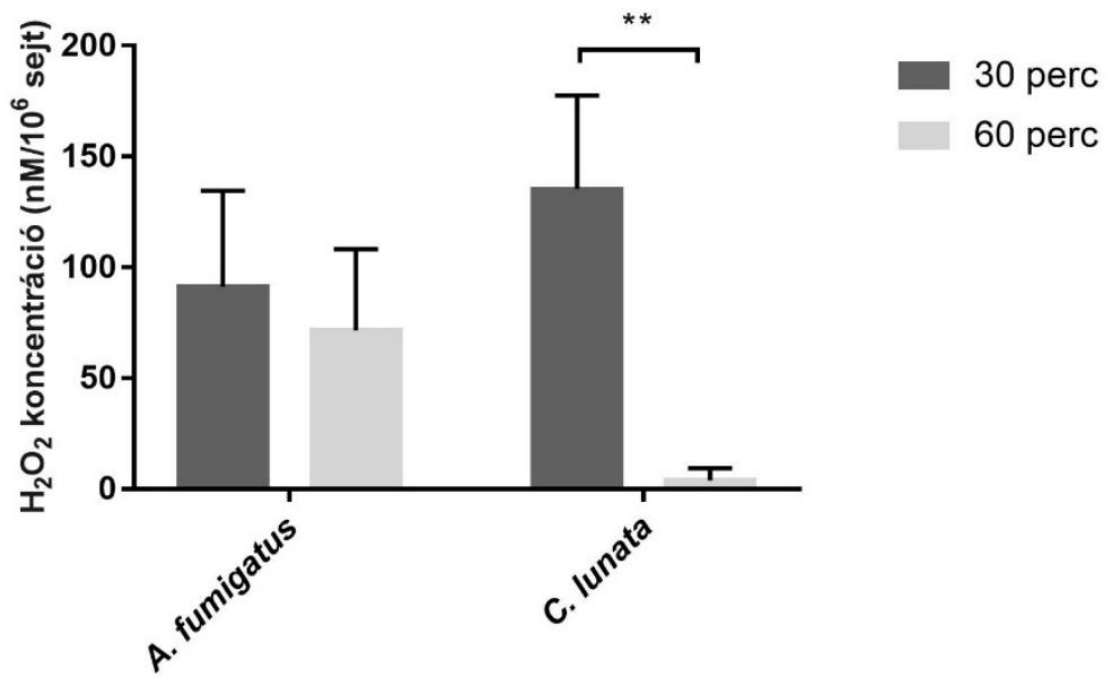

28. ábra: A neutrofil granulociták extracelluláris $\mathrm{H}_{2} \mathrm{O}_{2}$ termelése szérum opszonizált gombák jelenétében, $10^{6}$ sejtre vonatkoztatva az interakció 30. és 60 . percében. $n=6$; a statisztikai analízist kétszempontos ANOVA módszerrel végeztük.

Érdekes, hogy a szérum opszonizáció nélkül, a csak a szolubilis faktor által aktiválódó sejtek esetében nem tapasztaltunk ROS termelést. Mint azt az 3.8.3. fejezetben tárgyaltuk, a MPO nem csupán az oxidatív burst folyamatában tölt be fontos szerepet, hanem egyéb leukociták toborzását is végzi (Johansson és mtsi. 1997, van der Veen és mtsi. 2009). Elképzelhetö, hogy a szolubilis faktor hatására termelödő MPO proinflammatorikus szabályozóként müködik.

A 60. percben mért szignifikáns $\mathrm{H}_{2} \mathrm{O}_{2}$ koncentrációbeli csökkenés hátterében állhat egy, a gomba által termelt, MPO-hoz hasonló haloperoxidáz, amely szintén HOCl-t hoz létre $\mathrm{H}_{2} \mathrm{O}_{2}$ felhasználásával (Butler 1998) vagy egyes mikrobiális haloperoxidázok esetében leírt kataláz aktivitással a $\mathrm{H}_{2} \mathrm{O}_{2}$-t vízzé és oxigénné bontja ( Morris és Hager 1966, Libby és mtsi. 1982, van Pee és Lingens 1985). Egy biotechnológiai tárgyú tanulmány felhívja a figyelmet a rokon C. inaequalis extracelluláris haloperoxidáz termelésére (Hansen és mtsi. 2003).

A haloperoxidázok vizsgálatára a C. lunata genomadatbázisából (Cochliobolus lunatus m118 v2.0, JGI MycoCosm) 9 haloperoxidázszerủ fehérjét kódoló gént azonosítottunk, amelyeket HPO1-9 géneknek neveztünk el. A gének szekvenciáit az 1. melléklet tartalmazza. A 9 aminosav szekvenciában ExPasy MyHits motívum kereső programjával végzett keresés alapján megtalálható a haloperoxidázokra jellemző 2-es típusú foszfatidil-sav foszfatáz (PAP2) motívum benne a PAP2 doménnel. 
A HPO1-8 gének expressziós változását $\mathrm{H}_{2} \mathrm{O}_{2}$ indukció hatására vizsgáltuk az indukció 30. és 60. percében (29. ábra). Az általunk használt törzs HPO9 gén szekvenciája valószínüleg eltér az m118-as törzsétől, ugyanis erre a génre tervezett indítószekvenciákkal nem sikerült a gént felszaporítanunk. A HPO1 gén esetében 30 perc után szignifikánsan nagyobb transzkripciós szintet detektáltunk, míg a többi gén esetében szignifikáns csökkenés vagy változatlan transzkripció volt megfigyelhető.

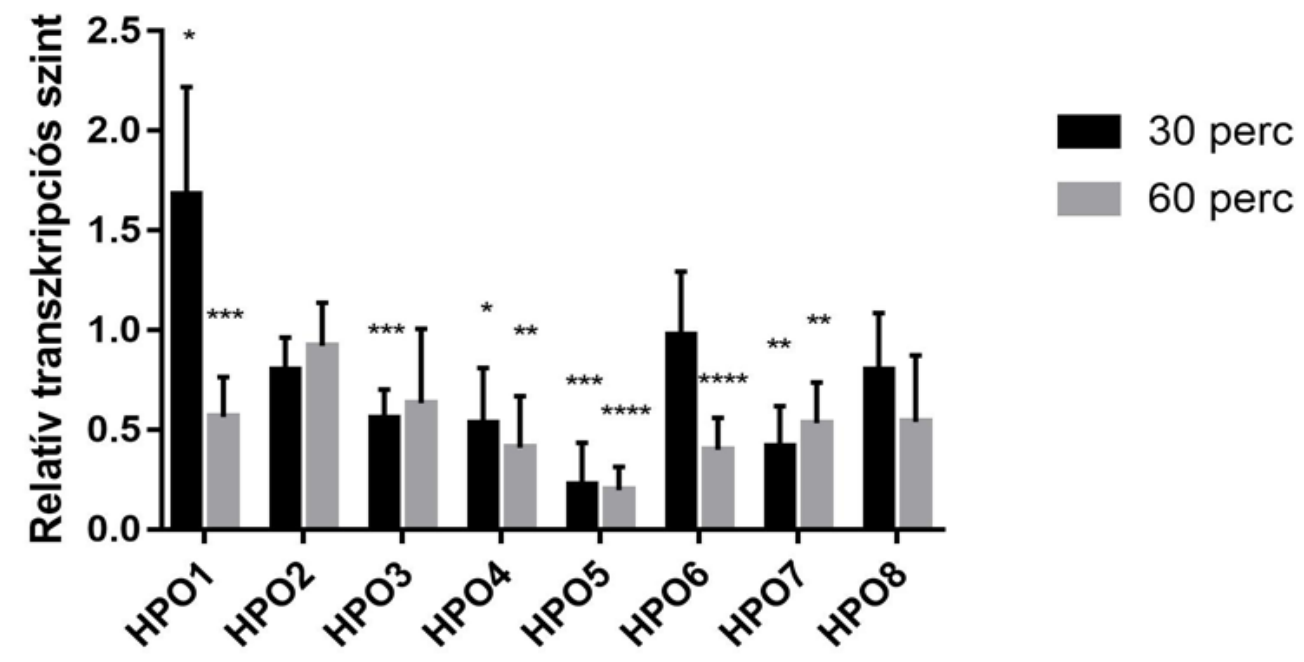

29. ábra: $C$. lunata feltételezhetően haloperoxidázt kódoló génjeinek relatív transzkripciós szintje $\mathrm{H}_{2} \mathrm{O}_{2}$ indukció hatására 30 és 60 perc elteltével. A relatív transzkripciós szinteket $\Delta \Delta \mathrm{C}_{\mathrm{T}}\left(2^{-\Delta \Delta \mathrm{C} t}\right)$ módszerrel határoztuk meg a kezeletlen gombánál tapasztalt génexpresszióhoz viszonyítva. A statisztikai analízist többszörös t-próbával végeztük az indukálatlan 30 és 60 perces mintákhoz képest, amelyek értékét 1-nek vettük (hamis találati aránnyal, $Q=10 \%$ ).

A HPO1 gén által kódolt fehérje aminosav sorrendje NCBI blastp illesztés alapján 93\% egyezést mutat a $C$. inaequalis vanádium kloroperoxidázzal (P49053), amelynek ismert a fehérje szerkezete (3.7 fejezet). A HPO1 fehérje aminosav szekvenciáját a CPO fehérjéhez illesztve látható, hogy a fehérje központi egységét alkotó $\alpha$-helix struktúráknál a két szekvencia nagyfokú hasonlóságot mutat (30. ábra). A HPO1 fehérjében is megtalálható az aktív centrumhoz és vanadát-ion megkötéséhez szükséges His aminosavak, valamint a vanádium központ kialakításában szerepet játszó $\mathrm{Ser}^{402}, \mathrm{Gly}^{403}, \mathrm{Lys}^{353}, \mathrm{Arg}^{360}$ és $\mathrm{Arg}^{490}$ aminosavak is (3.7 fejezet). A szerkezeti hasonlóság alapján valószínúleg a HPO1 fehérje szintén vanádium kloroperoxidáz. Ezen enzimek esetében még nem írtak le kataláz aktivitást (Renirie és mtsi. 2009). 


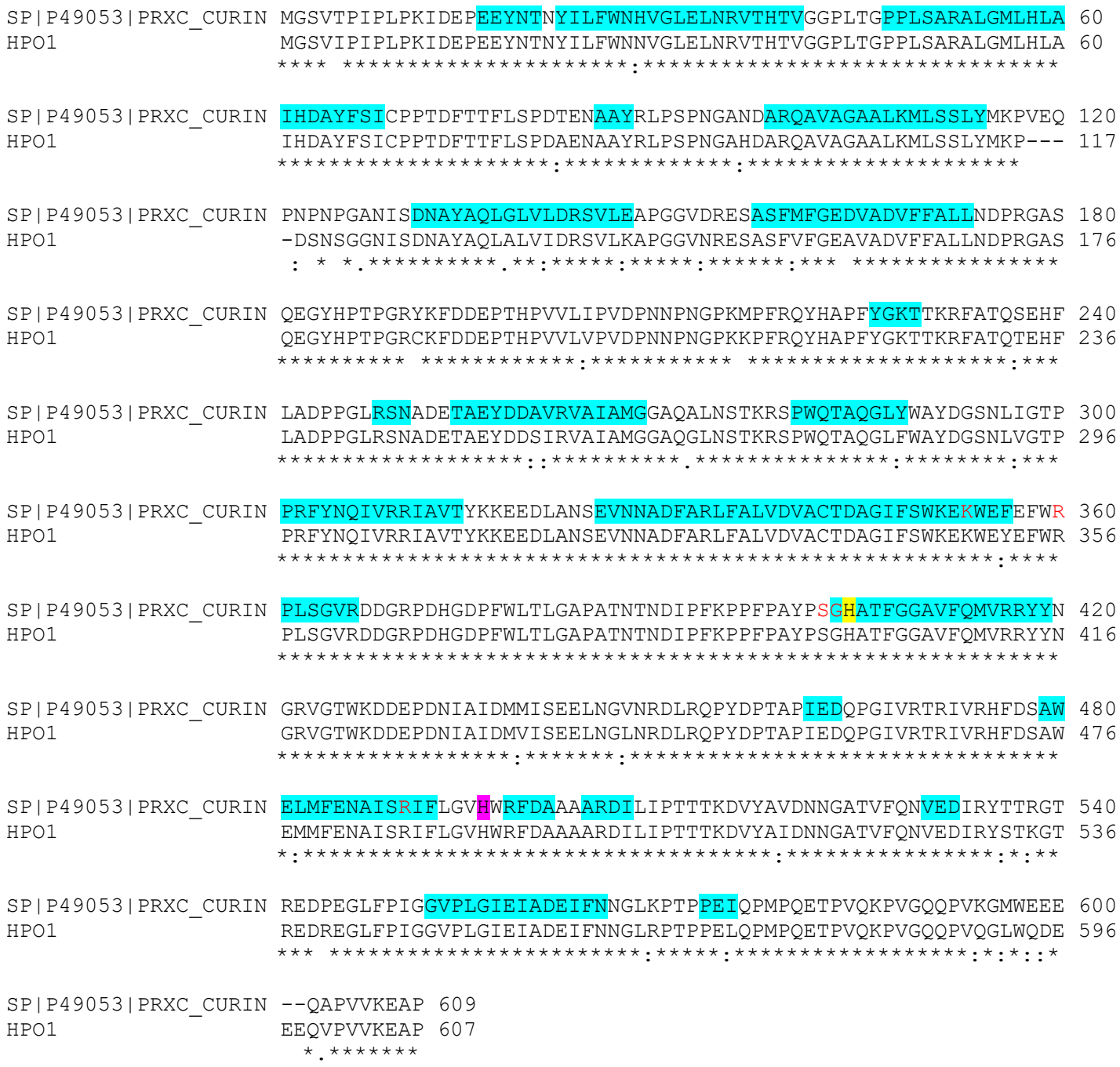

30. ábra: A $C$. inaequalis vanádium kloroperoxidáz és $C$. lunata HPO1 fehérjék aminosav szekvencia illesztése. A $C$. inaequalis fehérjeszekvenciájában az $\alpha$-helix struktúrát kék szín, az aktív centrumot sárga, a fémion kötőhelyet lila szín jelöli. A vanádium központ létrehozásában résztvevő egyéb aminosavakat piros betűvel jelöltük. Az illesztést és a szerkezeti elemek azonosítását UniProt BLAST programmal készítettük.

A HPO2-9 fehérjék más fehérjék szekvenciáihoz való legnagyobb azonossági százalékát az 5. táblázat foglalja össze. Ezen hasonló fehérjék funkciója más organizmusokban sem tisztázott, de mivel az indukció hatására nem tapasztaltuk a gének felülszabályozását, a $\mathrm{H}_{2} \mathrm{O}_{2}$ átalakításában valószínüleg nem vesznek részt a vizsgált körülmények között. 
5. táblázat: A HPO2-9 gének által kódolt fehérjék aminosav szekvenciáinak legmagasabb százalékú azonossága és lefedettsége más organizmusok fehérjéivel.

\begin{tabular}{|c|c|c|c|}
\hline $\begin{array}{l}\text { Kódoló } \\
\text { gén }\end{array}$ & Legnagyobb hasonlóságot mutató gén & Azonosság & Lefedettség \\
\hline HPO2 & B. maydis hipotetikus fehérje COCC4DRAFT 43272 & $58 \%$ & $97 \%$ \\
\hline HPO3 & $\begin{array}{l}\text { Bipolaris oryzae hipotetikus fehérje COCMIDRAFT } \\
93739\end{array}$ & $89 \%$ & $100 \%$ \\
\hline HPO4 & B. maydis hipotetikus fehérje COCC4DRAFT 41040 & $94 \%$ & $100 \%$ \\
\hline HPO5 & B. maydis hipotetikus fehérje COCC4DRAFT 54428 & $89 \%$ & $100 \%$ \\
\hline HPO6 & $\begin{array}{l}\text { Stemphylium lycopersici PAP2 domént tartalmazó } \\
\text { fehérje }\end{array}$ & $76 \%$ & $96 \%$ \\
\hline HPO7 & B. victoriae hipotetikus fehérje COCVIDRAFT 104494 & $86 \%$ & $100 \%$ \\
\hline HPO8 & $\begin{array}{l}\text { Pyrenophora teres } f \text {. teres hipotetikus fehérje PTT } \\
08684\end{array}$ & $91 \%$ & $100 \%$ \\
\hline HPO9 & $\begin{array}{l}\text { Bipolaris sorokiniana hipotetikus } \\
\text { COCSADRAFT } 177466\end{array}$ & $91 \%$ & $98 \%$ \\
\hline
\end{tabular}

Az interakció során a NET képződést is megvizsgáltuk. A szérum opszonizált $A$. fumigatus-szal való 3 órás interakcióban jól megfigyelhető a kromatin dekondenzálódása és az extracelluláris háló megjelenése, míg azonos körülmények között a $C$. lunata jelenlétében a sejtek láthatóan felismerik a gombát, kapcsolódnak a hifához, azonban a sejtmag lobuláris szerkezete megmarad, NET képzés pedig nem látható (31. ábra). Egyéb körülmények között a sejtek hifa körüli aggregációja is elmaradt.
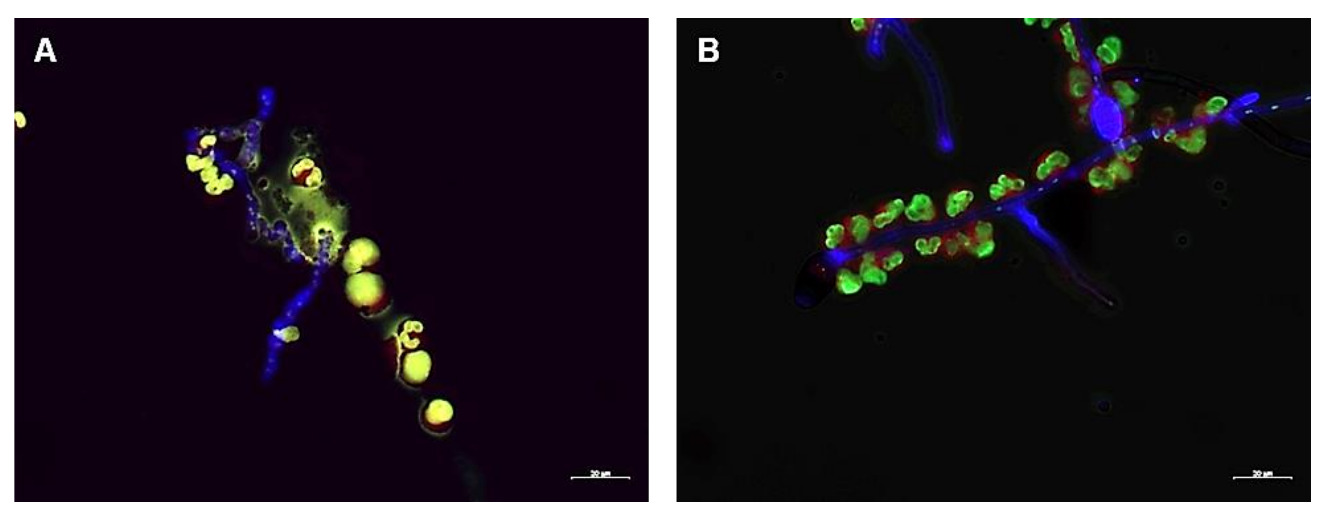

31. ábra: Neutrofil granulociták NET képzése A. fumigatus (A) és $C$. lunata (B) hifák jelenlétében, 3 órás interakciót követően. A méretskála $20 \mu \mathrm{m}$-t jelöl. 
A NET képzés egyes stádiumaiban levő sejtek kvantifikációjánál azt tapasztaltuk, hogy az A. fumigatus hifái köré gyült sejtek között intakt és felbomlott sejtmagú sejtek, valamint már netotikus sejtek is megtalálhatók, míg a $C$. lunata hifái körül csak intakt sejtmagú sejtek voltak megfigyelhetők (32. ábra)

A. fumigatus

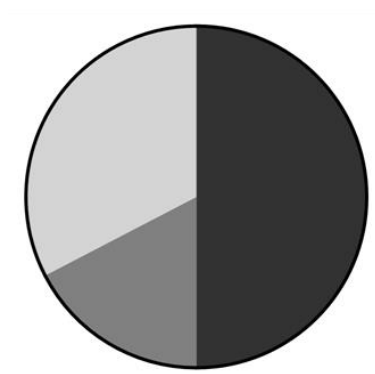

C. Iunata

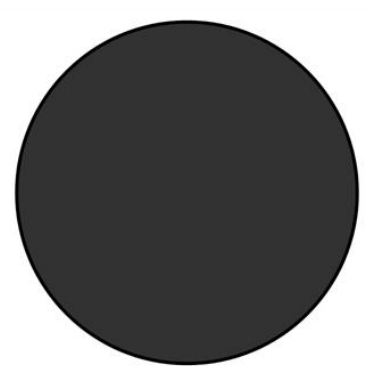

32. ábra: A NET képzés egyes stádiumaiban lévő sejtek százalékos megoszlása A. fumigatus és $C$. lunata szérum opszonizált hifái hatására. A stádiumokat a DNS kiterjedésének mértékével jellemeztük: intakt sejtmag: DNS $\leq 50 \mu \mathrm{m}^{2}$; felbomlott sejtmagmembrán: $50 \mu \mathrm{m}^{2} \leq \mathrm{DNS} \leq 90 \mu \mathrm{m}^{2}$; netotikus sejtek: DNS $\geq 90 \mu \mathrm{m}^{2}$. A sejtek DNS-ének kiterejedését SYTOX Green festés alapján határoztuk meg ImageJ szoftver segítségével.

A ROS-ok NET képzésben betöltött szabályozó szerepét több tanulmány is alátámasztotta (Fuchs és mtsi. 2007, Behnen és mtsi. 2017). A $\mathrm{H}_{2} \mathrm{O}_{2}$ mennyiségének radikális csökkenése magyarázhatja a NET képzés elmaradását, ez azonban azt is feltételezi, hogy a HPO1 gén által kódolt haloperoxidáz, amely szerkezet alapján nem rendelkezik kataláz aktivitással, nem vesz részt ebben a folyamatban, hiszen a NET képzés nem indukálódik. A NET képzés hiánya $C$. lunata jelenlétében ellentmond annak a szakirodalomban leírt jelenségnek, amely szerint a NET megjelenése a patogén méretétöl függene (Branzk és mtsi. 2014).

Mivel szérum opszonizáció hatására a neutrofil granulociták a hifák köré aggregálódtak, megvizsgáltuk a gombák életképességét az interakciót követő 3. órában (33. ábra). Azt tapasztaltuk, hogy míg a sejtek az A. fumigatus-t hatékonyan képesek ölni, a $C$. lunata életképessége nem csökkent az interakció után. 


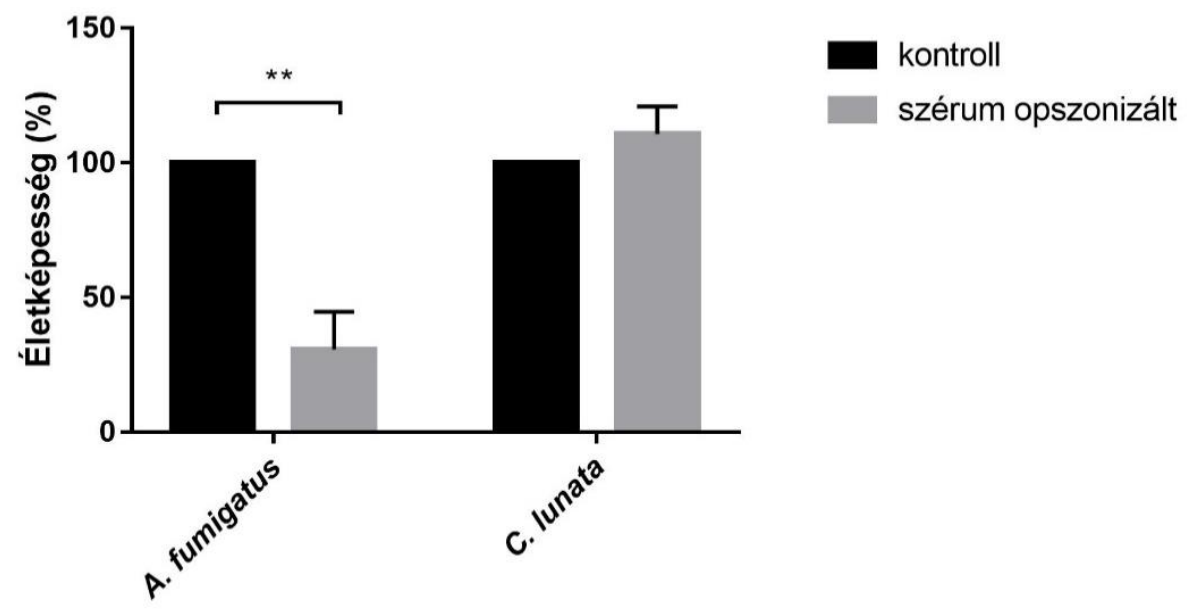

33. ábra: A szérum opszonizált gombatörzsek életképessége a neutrofil granulocitákkal való 3 órás interakció után a kontrollhoz viszonyított százalékos értékben kifejezve. Kontrollként az azonos körülmények között, neutrofil sejtek nélkül nevelt gombákat használtuk. $\mathrm{n}=9$; a statisztikai analízist kétszempontos ANOVA módszerrel végeztük.

A $\mathrm{H}_{2} \mathrm{O}_{2}$ mennyiségének csökkenésére két hipotézist vizsgáltunk, amelyeket az alábbiakban ismertetünk.

\subsubsection{A melanin, mint antioxidáns jelenléte}

A melaninok antioxidáns kapacitását szakirodalmi adatok támasztják alá (Jacobson és mtsi. 1995, Wang és mtsi. 1995). Az interakció 60. percében lecsökkent $\mathrm{H}_{2} \mathrm{O}_{2}$ szint magyarázható lenne a gomba által termelt melanin szabadgyök semlegesítő hatásával, ezért az interakciós felülúszóban vizsgáltuk a melanin jelenlétét. Az interakcióból származó felülúszó savanyítása során nem tapasztaltuk csapadék képződését, a PTFE membránon sem volt látható pigment szürlet. Hét napos tenyésztés után is vizsgáltuk a melanin termelést mKRPG közegben. A savanyítás után nem volt megfigyelhető a melanin kiválása.

Feltételezhetö, hogy ebben a közegben a gomba nem bocsát ki melanint az extracelluláris térbe, tehát a $\mathrm{H}_{2} \mathrm{O}_{2}$ semlegesítése sem a pigment által történik.

\subsubsection{Az extracelluláris környezet savasodása}

Szakirodalmi adatok alapján a mikrobák és a neutrofil sejtek interakciója során az extracelluláris savasodás gátolja a neutrofil funkciókat, elsősorban az oxidatív burst gátlásán keresztül (Behnen és mtsi. 2017), ezért az interakció 1. és 3. órájában meghatároztuk a közeg pH-ját (30. ábra). 
Mivel a szérum hozzáadása lúgosította a közeget, az egyes kísérleti eredményeket mindig a megfelelő kontrollhoz hasonlítottuk. A gomba kontrollok 1 és 3 óra elteltével is savanyították a környezetüket. Ezzel ellentétben a sejtek jelenlétében A. fumigatus esetében nem tapasztaltuk a közeg savanyítását egyik vizsgált időpontban sem. C. lunata esetében szérum opszonizáció után a sejtek jelenlétében is megfigyelhető volt a pH csökkenése már 60 perc elteltével is. 3 óra után szignifikánsan alacsonyabb pH-t mértünk ebben az esetben, mint a kontroll sejteknél (30. ábra). A Behnen és munkatársai (2017) által publikált tanulmány szerint a 6,5 körüli pH már elegendő a neutrofil funkciók gátlásához.

1 óra
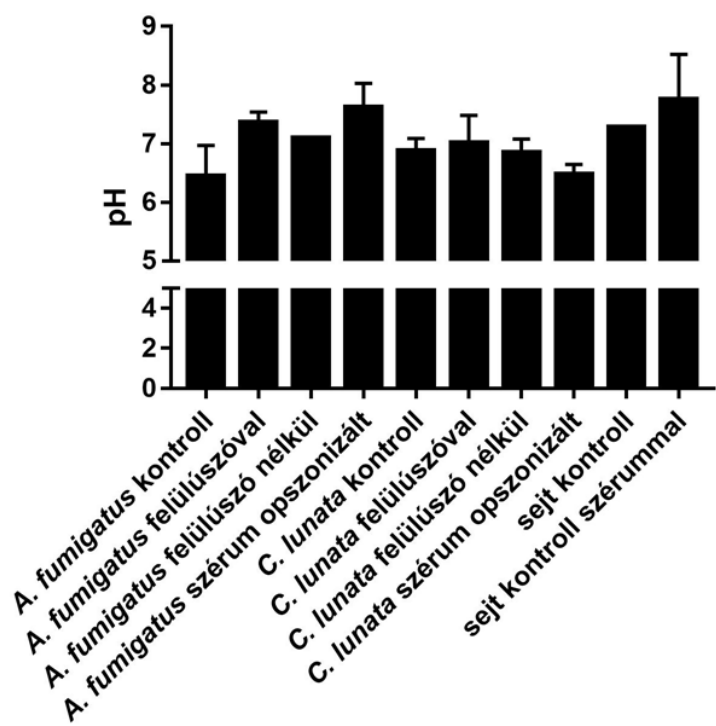

3 óra

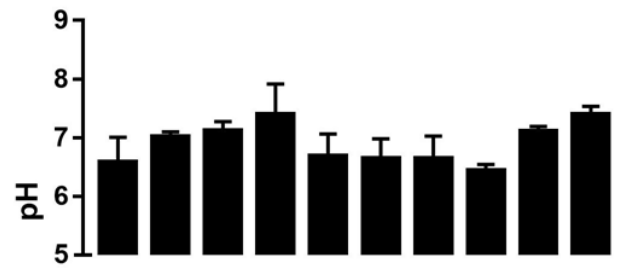

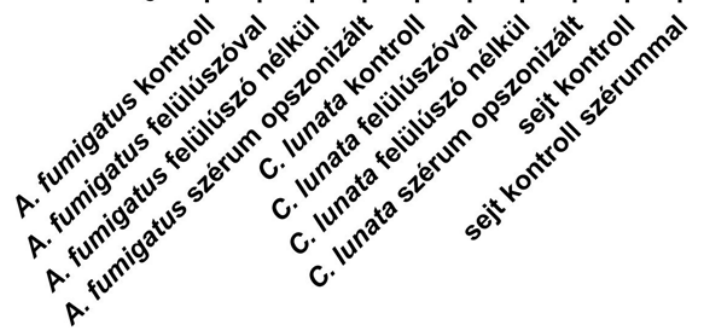

30. ábra: Az extracelluláris pH alakulása a neutrofil granulociták és a gombák interakciójában 60 perc (A) és 3 óra (B) elteltével. A gomba kontrollok a sejtek nélkül, míg a sejt kontroll a gombák nélkül azonos körülmények között inkubált állapotot jelöli. Az ábrán használt további jelölések: felülúszóval - a neutrofil granulocitákat közvetlenül adtuk a csírázó konídiumokhoz; felülúszó nélkül - a neutrofilek hozzáadása elött a fiatal hifákat mKRPG pufferrel mostuk; szérum opszonizált - a gombákat a csírázás utolsó órájában megfelelö donorból származó szérummal opszonizáltuk. A szérum opszonizációs körülmények statisztikai elemzése a szérummal és szérum nélkült inkubált sejtes kontrollhoz viszonyítva is megtörtént, míg a többi esetben a szérum nélkül inkubált sejtes kontrollt használtuk. $\mathrm{n}=6$; a statisztikai analízist kétszempontos ANOVA módszerrel végeztük.

Ezen eredmények magyarázatot adnak a $\mathrm{H}_{2} \mathrm{O}_{2}$ mennyiségének csökkenésére és ezzel együtt a NET képzés elmaradására is. A C. lunata opszonizációja nélkül végzett interakciós kísérletekben (felülúszóval és felülúszó nélkül) is megfigyelhető volt kismértékü pH csökkenés, azonban ezekben az esetekben nem tapasztaltuk a gomba és a sejtek tényleges kapcsolatát (6.3. fejezet). 


\section{7 Összefoglalás}

A Curvularia fajok mind humán egészségügyi problémaként, mind pedig gazdasági kártevőként gyakorlati jelentőséggel bíró fonalas gombák. Növényi patogénként számos kutatás foglalkozik ezen fajokkal, azonban humánpatogén szempontból kevés információnk van a nemzetség képviselőiről. Ezek a gombák feohifomikózisok kialakítására képesek, melyek egészséges emberekben elsősorban lokális, immunszuppresszált betegekben invazív, illetve disszeminált fertőzésként jelentkeznek. A nemzetség tagjai közül humán fertőzésekböl leggyakrabban a $C$. lunata, a $C$. hawaiiensis és a $C$. spicifera fajok képviselöit izolálják, amely fajok erősen melanizáltak, ezért a pigment esetleges virulenciafaktorként betöltött szerepe is jól vizsgálható esetükben. Mivel az opportunista fonalas gombafertőzések esetszáma az utóbbi évtizedekben növekedést mutat, amely magában foglalja a kevésbé jellemzett nem Asperillus fajokat is, az ilyen irányú kutatások fontossága kiemelkedő.

Munkánk során célul tüztük ki a $C$. lunata interakciójának vizsgálatát három, a veleszületett immunválasz folyamatában alapvető szerepet játszó immunsejttípussal.

A monocitákkal és makrofágokkal való interakció modellezésére a THP-1 sejtvonalat használtuk, ahol a sejtek válaszát a konídiumok és hifák jelenlétében is megvizsgáltuk. A hifák által kiváltott választ a $C$. hawaiiensis és a $C$. spicifera esetében is tanulmányoztuk. A neutrofil granulociták és a $C$. lunata fiatal hifáinak interakcióját primer immunsejtek felhasználásával modelleztük.

\section{Monociták válasza a Curvularia izolátumokra}

A THP-1 monociták a $C$. lunata nagy, melanizált konídiumaival nem léptek interakcióba, a fagocitózis vizsgálatban a kölcsönhatásban lévő sejtek aránya nagyon alacsony volt. A pozitív események többsége nem volt tényleges internalizáció. Mivel a melanin hatással lehet a fagocitózisra, a vizsgálatot elvégeztük melanin bioszintézist gátló körülmények közt termelt konídiumokkal is, azonban az interakcióba lépő sejtek arányát nem növelte a konídiumfal melanin tartalmának hiánya. A THP-1 monociták sem a melanizált, sem pedig a melanin gátolt konídiumok jelenlétében nem termeltek TNFa, IL6, IL8 vagy IL10 citokineket.

A monociták többek között mikrobiális szignálok hatására aktiválódni képesek, amely során a sejtek felszíni receptor mintázata megváltozik. Az aktiváció elindítja a differenciáció 
folyamatát, amely után a monociták makrofággá vagy dendritikus sejtté alakulnak, vagy fenntartják monocita állapotukat. A monociták az antigén prezentációban is részt vesznek.

A THP-1 monociták aktivációját mind a konídiumok, mind a hifák jelenlétében vizsgáltuk. A $C$. lunata konídiumai nem váltották ki a sejtek aktivációját, valószínúleg antigén prezentáció sem történik, amely a kismértékủ interakcióval magyarázható. A melanin hiánya a konídiumfalban nem befolyásolta az aktiváció és az antigén prezentáció elmaradását. A hifák jelenlétében sem tapasztaltuk az aktivációra jellemző génexpressziós mintázatot egyik Curvularia izolátum jelenlétében sem, habár a $C$. lunata esetében a sejtek aggregációja volt megfigyelhető a késői immunválasz vizsgálatánál. Ebben az esetben sem következtethettünk antigén prezentációra. A C. hawaiiensis és $C$. spicifera hifái nem váltották ki a monociták csoportosulását. A monociták nem voltak képesek csökkenteni a gombák életképességét az interakció során.

A THP-1 monociták hifák hatására bekövetkezö citokintermelését is megvizsgáltuk. A C. hawaiiensis és $C$. spicifera nem váltotta ki a mért citokinek termelését. A C. lunata hifák jelenlétében tapasztalt IL10 antiinflammatorikus citokin termelés összefüggésben állhat a gomba által okozott fertőzések krónikus jellegével, a gyulladásos válasz gátlására utalhat a HLADRA gén alulszabályozása is. Ugyanakkor a gomba az IL8 termelését is indukálta, amely a neutrofil granulociták toborzásáért felelős legfontosabb attraktáns.

\section{Makrofágok válasza a Curvularia izolátumokra}

A Curvularia izolátumok interakcióját érlelt THP-1 sejtekkel is vizsgáltuk, amely makrofágokhoz hasonló fenotípust mutat. A C. lunata konídiumait az érlelt sejtek hatékonyabban ismerték fel, a fagocitáló sejtek aránya megnőtt. Az interakciós események nagy része tényleges internalizáció volt a konídiumok méretétől függetlenül.

A hifák ebben az esetben nem indukálták a sejtek aggregációját, azonban azok megjelenése után is megfigyelhető volt a sejtek konídiumhoz történő kapcsolódása, tehát a makrofágok a konídiumok felismerésében játszhatnak szerepet.

A sejtekkel való interakció nem csökkentette az izolátumok életképességét, önmagukban a makrofágok nem voltak képesek hatékony ölésre.

\section{Neutrofil granulociták válasza $C$. lunata fiatal hifáira}

A vizsgálatok során megállapítottuk, hogy a neutrofil granulociták a $C$. lunata hifáit szérum dependens mechanizmussal ismerik fel, amely indukálja az oxidatív burst folyamatát 
a sejtekben. A gomba termelhet egy szolubilis faktort, amely önmagában is kiváltja a sejtek aktiválódását, azonban ROS felszabadulást ez nem eredményez. A nagyméretü mikrobákkal szemben, mint a fonalas gombák, a NET képzést fontos effektor funkciónak tartják a neutrofilek esetében. A $C$. lunata jelenléte azonban nem váltotta ki a NET formálását, habár a sejtek kapcsolódtak a hifákhoz. A NET hiányát magyarázhatja a $\mathrm{H}_{2} \mathrm{O}_{2}$ szintjének radikális csökkenése az interakció során, hiszen a NET képzés szabályozásában a reaktív oxigén gyökök fontos szerepet játszanak. Eredményeink alapján a gomba savanyítja a környezetét az interakció során, amely pH változás gátolja a neutrofil funkciókat, elsősorban az oxidatív burst gátlásán keresztül. Ezen körülmények között a neutrofil granulociták nem voltak képesek hatékony ölésre a $C$. lunata-val szemben

Eredményeink alapján a monociták a $C$. lunata hifáit, míg a makrofágok a konídiumokat ismerik fel. A monociták esetében az antiinflammatorikus folyamatok előtérbe kerülését figyeltük meg, amely hozzájárulhat a krónikus fertőzések kialakulásához. A neutrofil granulociták szérum opszonizáció után képesek felismerni a gomba hifáit, azonban a gomba gátolja a neutrofil effektor funkciókat. A vizsgált sejttípusok egyike sem volt képes a $C$. lunata vagy a többi Curvularia izolátum hatékony ölésére izolált körüilmények között. Mivel az interakciók során immunreguláló molekulák termelését is kimutattuk, mint a monociták esetében a neutrofilek toborzásáért felelős IL8 termelést, vagy az effektor funkciókat nem indukáló MPO felszabadulást neutrofil granulociták esetében, feltételezhető, hogy ez a sejt-sejt kommunikáció a $C$. lunata elleni védekezésben nagyon fontos szerepet játszik. 


\section{Summary}

Curvularia species are filamentous fungi having practical significance for both the human health and the agriculture. Several studies have been performed on these species as plant pathogens but from a human pathogenic concept, we have only few information about them. Some of these fungi can cause human phaeohyphomycoses (i.e. mycoses caused by dematiaceous fungi) that manifest as local infections in healthy individuals and as invasive infection in immunosuppressed patients. Among the members of the genus, C. lunata, $C$. hawaiiensis and C. spicifera are the most frequently isolated species from human infections, that are highly melanized hence the role of the pigment as a potential virulence factor can be investigated.As far as in the last decades, case number of infections caused by opportunistic pathogenic filamentous fungi including the less characterized non-Aspergillus species have been increasing, research of these fungi became an intensively studies area.

During this study, our aim was to examine the interaction of $C$. lunata with three cell types of the innate immunity.

To model the interaction with monocytes and macrophages, we used the THP-1 cell line and examined the response of the cells to conidia and hyphae as well. Response to hyphae was analyzed in case of $C$. hawaiiensis and $C$. spicifera, too. Interaction of neutrophil granulocytes and young hyphae of $C$. lunata was simulated using primer immune cells.

\section{$\underline{1 . \text { Response of monocytes to Curvularia strains }}$}

THP-1 monocytes did not interact with the large and melanized conidia of C. lunata, and the percentage of connecting cells was very low in phagocytosis assay. Majority of positive events was were not actual internalization. As melanin can affect phagocytosis, the assay was performed with conidia harvested from cultures grown on melanin biosynthesis inhibitory medium. However, the lack of melanin in the conidial cell wall did not increase the ratio of the connecting cells. THP-1 monocytes didn't produce any TNFa, IL6, IL8 or IL10 cytokines, neither in response to melanin inhibited nor to melanized conidia.

Monocytes can be activated by microbial signals, and during this process, the pattern of the cell surface receptors changes. Activation may start differentiation of monocytes to macrophage or dendritic cell but can maintain the monocytic state as well. Monocytes also participate in the antigen presentation. 
Activation of THP-1 monocytes was examined in presence of both conidia and hyphae. Conidia of C. lunata didn't induce activation of cells, probably antigen presentation is also missing, that can be explained by the low level of interaction. Absence of melanin from the conidial cell wall had no effect on the lack of activation or antigen presentation. We did not observe the gene expression pattern specific to activation in the presence of hyphae of any tested Curvularia strain, although during investigation of late immune response to C. lunata, aggregation of monocytes could be seen around the hyphae. In this case, we also could not suppose antigen presentation. Hyphae of $C$. hawaiiensis and $C$. spicifera didn't induce aggregation of monocytes. The cells could not reduce viability of fungi during the interaction.

Cytokine production of THP-1 monocytes was also analyzed as an effect of fungi. $C$. hawaiiensis and $C$. spicifera did not induce the release of the examined cytokines. Production of anti-inflammatory IL10 cytokine as a response to $C$. lunata hyphae can be related to the chronic nature of infections caused by the fungus. Downregulation of HLADRA can refer to the inhibition of inflammation. At the same time, $C$. lunata induced the release of IL8, which is the main attractant for neutrophil granulocytes.

\section{Response of macrophages to Curvularia strains}

Interaction of Curvularia species was investigated with differentiated THP-1 cells showing macrophage-like phenotype. Conidia of $C$. lunata was recognized more efficiently by the differentiated cells and the ratio of phagocytizing cells increased. The majority of interactions was actual internalization despite the size of the conidia.

Hyphae in this case did not induce aggregation of cells but connection of macrophages and conidia was seen even after germination, so macrophages may play role in the recognition of conidia.

Interaction with the cells did not reduce the viability of strains and macrophages on their own were not capable of efficient killing.

\section{Response of neutrophil granulocytes to young hyphae of $C$. lunata}

During our experiments, we concluded that neutrophil granulocytes could recognize $C$. lunata hyphae in a serum dependent way. This process induced oxidative burst in the cells. Fungus could produce a soluble factor, which was able to trigger the activation of cells but did not provoke ROS generation. NET formation is considered as an important effector function of neutrophils against large microbes. Presence of $C$. lunata did not trigger NET 
formation, although cells attached to the hyphae. Absence of NET can be explained by the radical decline in the concentration of hydrogen peroxide during the interaction, as formation of NET is regulated by ROS. According to our results, the fungi acidifies its environment during the interaction. This $\mathrm{pH}$ change inhibits neutrophil functions primarily by the blockage of oxidative burst. Under these circumstances, neutrophil granulocytes could not kill efficiently $C$. lunata.

Based on our results, monocytes recognize hyphae of $C$. lunata while macrophages react to the conidia. In case of monocytes, we noticed the anti-inflammatory processes to become conspicuous, that can correlate with the development of chronic infections. Neutrophil granulocytes can recognize fungal hyphae after serum opsonization, but the fungi can block effector functions of neutrophils. None of the investigated cell types could kill $C$. lunata or the other Curvularia strains under these isolated circumstances. While during interactions we detected the production of immunregulating molecules like IL8 in case of monocytes (that is responsible for the recruitment of neutrophils) or MPO release by neutrophil granulocytes that did not induce the effector functions of the cells, we could assume that protection against $C$. lunata may depend on this cell-cell communication. 


\section{Irodalomjegyzék}

Akira, S., S. Uematsu \& O. Takeuchi (2006) Pathogen recognition and innate immunity. Cell, $124,783-801$.

Alture-Werber, E. \& S. C. Edberg (1985) An animal model of Curvularia geniculata and its relationship with human disease. Mycopathologia, 89, 69-73.

Ambrosetti, D., V. Hofman V., L. Castillo, M. Gari-Toussaint \& P. Hofman (2006) An expansive paranasal sinus tumour-like lesion caused by Bipolaris spicifera in an immunocompetent patient. Histopathology, 49, 660-2.

Ammon, C., S. P. Meyer, L. Schwarzfischer, S. W. Krause, R. Andreesen \& M. Kreutz (2000) Comparative analysis of integrin expression on monocyte-derived macrophages and monocyte-derived dendritic cells. Immunology, 100, 364-9.

Andrianaki, A. M., I. Kyrmizi, K. Thanopoulou, C. Baldin, E. Drakos, S. S. M. Soliman, A. C. Shetty, C. McCracken, T. Akoumianaki, K. Stylianou, P. Ioannou, C. Pontikoglou, H. A. Papadaki, M. Tzardi, V. Belle, E. Etienne, A. Beauvais, G. Samonis, D. P. Kontoyiannis, E. Andreakos, V. M. Bruno, A. S. Ibrahim \& G. Chamilos (2018) Iron restriction inside macrophages regulates pulmonary host defense against Rhizopus species. Nat Commun, 9, 3333.

Antachopoulos, C. \& E. Roilides (2005) Cytokines and fungal infections. Br J Haematol, 129, 583-96.

Aplin, A. E., A. Howe, S. K. Alahari \& R. L. Juliano (1998) Signal transduction and signal modulation by cell adhesion receptors: the role of integrins, cadherins, immunoglobulin-cell adhesion molecules, and selectins. Pharmacol Rev, 50, 197263.

Arai, Y., Y. Nishinaka, T. Arai, M. Morita, K. Mizugishi, S. Adachi, A. Takaori-Kondo, T. Watanabe \& K. Yamashita (2014) Uric acid induces NADPH oxidase-independent neutrophil extracellular trap formation. Biochem Biophys Res Commun, 443, 556-61.

Arif, S. \& J. R. Perfect (2017) Emergence of the molds other than Aspergillus in immunocompromised patients. Clin Chest Med, 38, 555-573.

Arnold, D. E. \& J. R. Heimall (2017) A Review of chronic granulomatous disease. Adv Ther, 34, 2543-2557.

Augier, S., T. Ciucci, C. Luci, G. F. Carle, C. Blin-Wakkach \& A. Wakkach (2010) Inflammatory blood monocytes contribute to tumor development and represent a privileged target to improve host immunosurveillance. J Immunol, 185, 7165-73.

Babior, B. M., J. D. Lambeth \& W. Nauseef (2002) The neutrophil NADPH oxidase. Arch Biochem Biophys, 397, 342-4.

Badiee, P., A. Alborzi \& M. Joukar (2011) Molecular assay to detect nosocomial fungal infections in intensive care units. Eur J Intern Med, 22, 611-5.

Balla, A., J. Pierson, J. Hugh, C. Wojewoda, P. Gibson \& L. Greene (2016) Disseminated cutaneous Curvularia infection in an immunocompromised host; diagnostic challenges and experience with voriconazole. J Cutan Pathol, 43, 383-7.

Baqui, A. A., T. F. Meiller, J. I. Kelley, B. F. Turng \& W. A. Falkler (1999) Antigen activation of THP-1 human monocytic cells after stimulation with lipopolysaccharide from oral microorganisms and granulocyte-macrophage colony-stimulating factor. $J$ Periodontal Res, 34, 203-13. 
Beckett, A. R., S. A. Kahn, R. Seay \& A. C. Lintner (2017) Invasive Curvularia infections in burn patients: a case series. Surgical Infections Case Reports, 2.

Bedard, K. \& K. H. Krause (2007) The NOX family of ROS-generating NADPH oxidases: physiology and pathophysiology. Physiol Rev, 87, 245-313.

Behnen, M., S. Moller, A. Brozek, M. Klinger \& T. Laskay (2017) Extracellular acidification inhibits the ROS-dependent formation of neutrophil extracellular traps. Front Immunol, 8, 184.

Behnsen, J., P. Narang, M. Hasenberg, F. Gunzer, U. Bilitewski, N. Klippel, M. Rohde, M. Brock, A. A. Brakhage \& M. Gunzer (2007) Environmental dimensionality controls the interaction of phagocytes with the pathogenic fungi Aspergillus fumigatus and Candida albicans. PLoS Pathog, 3, e13.

Ben-Ami, R., R. E. Lewis, Raad, II \& D. P. Kontoyiannis (2009) Phaeohyphomycosis in a tertiary care cancer center. Clin Infect Dis, 48, 1033-41.

Benedict, K. \& B. J. Park (2014) Invasive fungal infections after natural disasters. Emerg Infect Dis, 20, 349-55.

Bentwood, B. J. \& P. M. Henson (1980) The sequential release of granule constitutents from human neutrophils. J Immunol, 124, 855-62.

Berbee, M. L., M. Pirseyedi \& S. Hubbard. (1999) Cochliobolus phylogenetics and the origin of known, highly virulent pathogens inferred from ITS and glyceraldehydes-3phosphate dehydrogenase gene sequences. Mycologia, 91, 964-977.

Bhatia, S., M. Fei, M. Yarlagadda, Z. Qi, S. Akira, S. Saijo, Y. Iwakura, N. van Rooijen, G. A. Gibson, C. M. St Croix, A. Ray \& P. Ray (2011) Rapid host defense against Aspergillus fumigatus involves alveolar macrophages with a predominance of alternatively activated phenotype. PLoS One, 6, e15943.

Bianchi, M., A. Hakkim, V. Brinkmann, U. Siler, R. A. Seger, A. Zychlinsky \& J. Reichenbach (2009) Restoration of NET formation by gene therapy in CGD controls aspergillosis. Blood, 114, 2619-22.

Boeddha, N. P., D. Kerklaan, A. Dunbar, E. van Puffelen, N. M. A. Nagtzaam, I. Vanhorebeek, G. Van den Berghe, J. A. Hazelzet, K. F. Joosten, S. C. Verbruggen, W. A. Dik \& G. J. Driessen (2018) HLA-DR expression on monocyte subsets in critically ill children. Pediatr Infect Dis J, 37, 1034-1040.

Borregaard, N. (2010) Neutrophils, from marrow to microbes. Immunity, 33, 657-70.

Bosshart, H. \& M. Heinzelmann (2016) THP-1 cells as a model for human monocytes. Ann Transl Med, 4, 438.

Branzk, N., A. Lubojemska, S. E. Hardison, Q. Wang, M. G. Gutierrez, G. D. Brown \& V. Papayannopoulos (2014) Neutrophils sense microbe size and selectively release neutrophil extracellular traps in response to large pathogens. Nat Immunol, 15, 101725.

Brinkmann, V., U. Reichard, C. Goosmann, B. Fauler, Y. Uhlemann, D. S. Weiss, Y. Weinrauch \& A. Zychlinsky (2004) Neutrophil extracellular traps kill bacteria. Science, 303, 1532-5.

Busch, R., C. H. Rinderknecht, S. Roh, A. W. Lee, J. J. Harding, T. Burster, T. M. Hornell \& E. D. Mellins (2005) Achieving stability through editing and chaperoning: regulation of MHC class II peptide binding and expression. Immunol Rev, 207, 24260 .

Butler, A. (1998) Vanadium haloperoxidases. Curr Opin Chem Biol, 2, 279-85. 
Butler, A., J. N. Carter \& M. T. Simpson. 2001. In Handbook of Metalloproteins, eds. I. Bertini, A. Sigel \& H. Sigel, 153-179. New York: Marcel Dekker Inc.

Carter, E. \& C. Boudreaux (2004) Fatal cerebral phaeohyphomycosis due to Curvularia lunata in an immunocompetent patient. J Clin Microbiol, 42, 5419-23.

Cavanna, C., E. Seminari, A. Pusateri, F. Mangione, F. Lallitto, M. C. Esposto \& F. Pagella (2014) Allergic fungal rhinosinusitis due to Curvularia lunata. New Microbiol, 37, 241-5.

Chang, Y. C., E. Graf \& A. M. Green (2018) Invasive curvularia infection in pediatric patients with hematologic malignancy identified by fungal sequencing. J Pediatric Infect Dis Soc.

Chanput, W., J. J. Mes \& H. J. Wichers (2014) THP-1 cell line: an in vitro cell model for immune modulation approach. Int Immunopharmacol, 23, 37-45.

Chapurin, N., C. Wang, D. M. Steinberg \& D. W. Jang (2016) Hyperprolactinemia secondary to allergic fungal sinusitis compressing the pituitary gland. Case Rep Otolaryngol, 2016, 7260707.

Chowdhary, A., K. Agarwal, S. Kathuria, S. N. Gaur, H. S. Randhawa \& J. F. Meis (2014) Allergic bronchopulmonary mycosis due to fungi other than Aspergillus: a global overview. Crit Rev Microbiol, 40, 30-48.

Chowdhary, A., H. S. Randhawa, V. Singh, Z. U. Khan, S. Ahmad, S. Kathuria, P. Roy, G. Khanna \& J. Chandra (2011) Bipolaris hawaiiensis as etiologic agent of allergic bronchopulmonary mycosis: first case in a paediatric patient. Med Mycol, 49, 760-5.

Clark, H. L., S. Abbondante, M. S. Minns, E. N. Greenberg, Y. Sun \& E. Pearlman (2018) Protein deiminase 4 and CR3 regulate Aspergillus fumigatus and beta-glucan-induced neutrophil extracellular trap formation, but hyphal killing is dependent only on CR3. Front Immunol, 9, 1182.

Cohen, M. S., R. E. Isturiz, H. L. Malech, R. K. Root, C. M. Wilfert, L. Gutman \& R. H. Buckley (1981) Fungal infection in chronic granulomatous disease. The importance of the phagocyte in defense against fungi. Am J Med, 71, 59-66.

Condon, B. J., D. Wu, N. Krasevec, B. A. Horwitz \& B. G. Turgeon. 2013. Comparative genomics of Cochliobolus phytopathogens. In Genomics of Plant-Associated Fungi and Oomycetes. eds. R. Dean, A. Lichens-Park \& C. Kole. Springer.

Conesa, A., P. J. Punt \& C. A. van den Hondel (2002) Fungal peroxidases: molecular aspects and applications. J Biotechnol, 93, 143-58.

Cortez, K. J., C. A. Lyman, S. Kottilil, H. S. Kim, E. Roilides, J. Yang, B. Fullmer, R. Lempicki \& T. J. Walsh (2006) Functional genomics of innate host defense molecules in normal human monocytes in response to Aspergillus fumigatus. Infect Immun, 74, 2353-65.

Couper, K. N., D. G. Blount \& E. M. Riley (2008) IL-10: the master regulator of immunity to infection. J Immunol, 180, 5771-7.

da Cunha, K. C., D. A. Sutton, A. W. Fothergill, J. Gene, J. Cano, H. Madrid, S. Hoog, P. W. Crous \& J. Guarro (2013) In vitro antifungal susceptibility and molecular identity of 99 clinical isolates of the opportunistic fungal genus Curvularia. Diagn Microbiol Infect Dis, 76, 168-74.

Dale, D. C., L. Boxer \& W. C. Liles (2008) The phagocytes: neutrophils and monocytes. Blood, 112, 935-45.

de Cassia, R. G. R. \& S. R. Pombeiro-Sponchiado (2005) Antioxidant activity of the melanin pigment extracted from Aspergillus nidulans. Biol Pharm Bull, 28, 1129-31. 
de Waal Malefyt, R., J. Abrams, B. Bennett, C. G. Figdor \& J. E. de Vries (1991) Interleukin 10(IL-10) inhibits cytokine synthesis by human monocytes: an autoregulatory role of IL-10 produced by monocytes. J Exp Med, 174, 1209-20.

Debourgogne, A., J. Dorin \& M. Machouart (2016) Emerging infections due to filamentous fungi in humans and animals: only the tip of the iceberg? Environ Microbiol Rep, 8, $332-42$.

Deepe, G. S., Jr. \& R. S. Gibbons (2003) Protective and memory immunity to Histoplasma capsulatum in the absence of IL-10. J Immunol, 171, 5353-62.

Drewry, A. M., E. A. Ablordeppey, E. T. Murray, E. R. Beiter, A. H. Walton, M. W. Hall \& R. S. Hotchkiss (2016) Comparison of monocyte human leukocyte antigen-DR expression and stimulated tumor necrosis factor alpha production as outcome predictors in severe sepsis: a prospective observational study. Crit Care, 20, 334.

Espinosa, V., A. Jhingran, O. Dutta, S. Kasahara, R. Donnelly, P. Du, J. Rosenfeld, I. Leiner, C. C. Chen, Y. Ron, T. M. Hohl \& A. Rivera (2014) Inflammatory monocytes orchestrate innate antifungal immunity in the lung. PLoS Pathog, 10, e1003940.

Faurschou, M., O. E. Sorensen, A. H. Johnsen, J. Askaa \& N. Borregaard (2002) Defensinrich granules of human neutrophils: characterization of secretory properties. Biochim Biophys Acta, 1591, 29-35.

Fernández-Fueyo, E., M. van Wingerden, R. Renirie, R. Wever, Y. Ni, D. Holtmann \& F. Hollmann (2015) Chemoenzymatic halogenation of phenols by using the haloperoxidase from Curvularia inaequalis. Chem Cat Chem, 7, 4035-4038.

Frank, T., Y. Esquenazi, M. Nigo, A. Wanger, B. Portnoy \& S. Shepard (2016) Disseminated phaeohyphomycosis with brain abscess and biliary invasion due to Bipolaris spp. in an immunocompetent patient. Ann Clin Lab Sci, 46, 439-42.

Fuchs, T. A., U. Abed, C. Goosmann, R. Hurwitz, I. Schulze, V. Wahn, Y. Weinrauch, V. Brinkmann \& A. Zychlinsky (2007) Novel cell death program leads to neutrophil extracellular traps. J Cell Biol, 176, 231-41.

Gadgil, N., M. Kupferman, S. Smitherman, G. N. Fuller \& G. Rao (2013) Curvularia brain abscess. J Clin Neurosci, 20, 173-5.

Gao, J.-X. \& J. Chen (2017a) Involvement of a polyketide synthetase CIPKS18 in the regulation of vegetative growth, melanin and toxin synthesis, and virulence in Curvularia lunata. The plant pathology journal, 33, 597-601.

Gao, J.-X., C.-J. Yu, M. Wang, J.-N. Sun, Y.-Q. Li \& J. Chen (2017) Involvement of a velvet protein $\mathrm{ClVelB}$ in the regulation of vegetative differentiation, oxidative stress response, secondary metabolism, and virulence in Curvularia lunata. Scientific Reports, 7, 46054-46054.

Gao, J. X. \& J. Chen (2017b) Involvement of a polyketide synthetase CIPKS18 in the regulation of vegetative growth, melanin and toxin synthesis, and virulence in Curvularia lunata. Plant Pathol J, 33, 597-601.

Gao, S., Y. Li, J. Gao, Y. Suo, K. Fu \& J. Chen (2014) Genome sequence and virulence variation-related transcriptome profiles of Curvularia lunata, an important maize pathogenic fungus. BMC Genomics, 15, 627.

Gao, S. G., F. H. Zhou, T. Liu, Y. Y. Li \& J. Chen (2013) A MAP kinase gene, Clk1, is required for conidiation and pathogenicity in the phytopathogenic fungus Curvularia lunata. J Basic Microbiol, 53, 214-23.

Gazendam, R. P., J. L. van Hamme, A. T. Tool, M. Hoogenboezem, J. M. van den Berg, J. M. Prins, L. Vitkov, F. L. van de Veerdonk, T. K. van den Berg, D. Roos \& T. W. 
Kuijpers (2016) Human neutrophils use different mechanisms to kill Aspergillus fumigatus conidia and hyphae: evidence from phagocyte defects. J Immunol, 196, 1272-83.

Gersuk, G. M., D. M. Underhill, L. Zhu \& K. A. Marr (2006) Dectin-1 and TLRs permit macrophages to distinguish between different Aspergillus fumigatus cellular states. $J$ Immunol, 176, 3717-24.

Ghuman, H. \& K. Voelz (2017) Innate and Adaptive Immunity to Mucorales. J Fungi (Basel), 3.

Goncalves, R. C., H. C. Lisboa \& S. R. Pombeiro-Sponchiado (2012) Characterization of melanin pigment produced by Aspergillus nidulans. World J Microbiol Biotechnol, 28, 1467-74.

Gonzalez, A. S., B. W. Bardoel, C. J. Harbort \& A. Zychlinsky (2014) Induction and quantification of neutrophil extracellular traps. Methods Mol Biol, 1124, 307-18.

Gordon, S. \& P. R. Taylor (2005) Monocyte and macrophage heterogeneity. Nat Rev Immunol, 5, 953-64.

Groll, A. H. \& T. J. Walsh (2001) Uncommon opportunistic fungi: new nosocomial threats. Clinical Microbiology and Infection, 7, 8-24.

Gultekin, Y., E. Eren \& N. Ozoren (2015) Overexpressed NLRC3 acts as an antiinflammatory cytosolic protein. J Innate Immun, 7, 25-36.

Gupta, R., V. Sharma, S. Sridhara, B. P. Singh \& N. Arora (2004) Identification of serine protease as a major allergen of Curvularia lunata. Allergy, 59, 421-7.

Hager, M., J. B. Cowland \& N. Borregaard (2010) Neutrophil granules in health and disease. J Intern Med, 268, 25-34.

Hansen, E. H., L. Albertsen, T. Schafer, C. Johansen, J. C. Frisvad, S. Molin \& L. Gram (2003) Curvularia haloperoxidase: antimicrobial activity and potential application as a surface disinfectant. Appl Environ Microbiol, 69, 4611-7.

Hasan, Z., R. Renirie, R. Kerkman, H. J. Ruijssenaars, A. F. Hartog \& R. Wever (2006) Laboratory-evolved vanadium chloroperoxidase exhibits 100-fold higher halogenating activity at alkaline $\mathrm{pH}$ : catalytic effects from first and second coordination sphere mutations. J Biol Chem, 281, 9738-44.

Hecht, H. J., H. Sobek, T. Haag, O. Pfeifer \& K. H. van Pee (1994) The metal-ion-free oxidoreductase from Streptomyces aureofaciens has an alpha/beta hydrolase fold. Nat Struct Biol, 1, 532-7.

Heinekamp, T., H. Schmidt, K. Lapp, V. Pähtz, I. Shopova, N. Köster-Eiserfunke, T. Krüger, O. Kniemeyer \& A. A. Brakhage (2015) Interference of Aspergillus fumigatus with the immune response. Seminars in Immunopathology, 37, 141-152.

Heinekamp, T., A. Thywissen, J. Macheleidt, S. Keller, V. Valiante \& A. A. Brakhage (2012) Aspergillus fumigatus melanins: interference with the host endocytosis pathway and impact on virulence. Front Microbiol, 3, 440.

Hoffmann, E., O. Dittrich-Breiholz, H. Holtmann \& M. Kracht (2002) Multiple control of interleukin-8 gene expression. J Leukoc Biol, 72, 847-55.

Hofmann, B., S. Tolzer, I. Pelletier, J. Altenbuchner, K. H. van Pee \& H. J. Hecht (1998) Structural investigation of the cofactor-free chloroperoxidases. J Mol Biol, 279, 889900.

Hymery, N., O. Puel, S. Tadrist, C. Canlet, H. Le Scouarnec, E. Coton \& M. Coton (2017) Effect of PR toxin on THP1 and Caco-2 cells: an in vitro study. World Mycotoxin Journal, 10, 375-386. 
Hynes, R. O. (1987) Integrins: a family of cell surface receptors. Cell, 48, 549-54.

Ibrahim-Granet, O., B. Philippe, H. Boleti, E. Boisvieux-Ulrich, D. Grenet, M. Stern \& J. P. Latge (2003) Phagocytosis and intracellular fate of Aspergillus fumigatus conidia in alveolar macrophages. Infect Immun, 71, 891-903.

Ingersoll, M. A., R. Spanbroek, C. Lottaz, E. L. Gautier, M. Frankenberger, R. Hoffmann, R. Lang, M. Haniffa, M. Collin, F. Tacke, A. J. Habenicht, L. Ziegler-Heitbrock \& G. J. Randolph (2010) Comparison of gene expression profiles between human and mouse monocyte subsets. Blood, 115, e10-9.

Ivanova, E. A. \& A. N. Orekhov (2016) Monocyte activation in immunopathology: cellular test for development of diagnostics and therapy. J Immunol Res, 2016, 4789279.

Jacobson, E. S., E. Hove \& H. S. Emery (1995) Antioxidant function of melanin in black fungi. Infect Immun, 63, 4944-5.

Jakubzick, C., E. L. Gautier, S. L. Gibbings, D. K. Sojka, A. Schlitzer, T. E. Johnson, S. Ivanov, Q. Duan, S. Bala, T. Condon, N. van Rooijen, J. R. Grainger, Y. Belkaid, A. Ma'ayan, D. W. Riches, W. M. Yokoyama, F. Ginhoux, P. M. Henson \& G. J. Randolph (2013) Minimal differentiation of classical monocytes as they survey steady-state tissues and transport antigen to lymph nodes. Immunity, 39, 599-610.

Jakubzick, C. V., G. J. Randolph \& P. M. Henson (2017) Monocyte differentiation and antigen-presenting functions. Nature Reviews Immunology, 17, 349.

Jhingran, A., K. B. Mar, D. K. Kumasaka, S. E. Knoblaugh, L. Y. Ngo, B. H. Segal, Y. Iwakura, C. A. Lowell, J. A. Hamerman, X. Lin \& T. M. Hohl (2012) Tracing conidial fate and measuring host cell antifungal activity using a reporter of microbial viability in the lung. Cell Rep, 2, 1762-73.

Johansson, M. W., M. Patarroyo, F. Oberg, A. Siegbahn \& K. Nilsson (1997) Myeloperoxidase mediates cell adhesion via the alpha $\mathrm{M}$ beta 2 integrin (Mac-1, CD11b/CD18). J Cell Sci, 110 ( Pt 9), 1133-9.

Kaur, J., L. Kautto, A. Penesyan, W. Meyer, L. D. H. Elbourne, I. T. Paulsen \& H. Nevalainen (2019) Interactions of an emerging fungal pathogen Scedosporium aurantiacum with human lung epithelial cells. Scientific Reports, 9, 5035.

Keshari, R. S., A. Jyoti, M. Dubey, N. Kothari, M. Kohli, J. Bogra, M. K. Barthwal \& M. Dikshit (2012) Cytokines induced neutrophil extracellular traps formation: implication for the inflammatory disease condition. PLoS One, 7, e48111.

Kessenbrock, K., M. Krumbholz, U. Schonermarck, W. Back, W. L. Gross, Z. Werb, H. J. Grone, V. Brinkmann \& D. E. Jenne (2009) Netting neutrophils in autoimmune smallvessel vasculitis. Nat Med, 15, 623-5.

Klebanoff, S. J. (1999) Myeloperoxidase. Proc Assoc Am Physicians, 111, 383-9.

Klebanoff, S. J. (2005) Myeloperoxidase: friend and foe. J Leukoc Biol, 77, 598-625.

Kolaczkowska, E. \& P. Kubes (2013) Neutrophil recruitment and function in health and inflammation. Nat Rev Immunol, 13, 159-75.

Koua, D., L. Cerutti, L. Falquet, C. J. Sigrist, G. Theiler, N. Hulo \& C. Dunand (2009) PeroxiBase: a database with new tools for peroxidase family classification. Nucleic Acids Res, 37, D261-6.

Krizsán, K., T. Papp, P. Manikandan, S. Shobana, M. Chandrasekaran, C. Vágvölgyi \& L. Kredics. 2015. Clinical importance of the genus Curvularia. In Medical Mycology: Current Trends and Future Prospects, ed. S.-G. M. Razzaghi-Abyaneh M, Rai M, 147-204. Boca Raton, FL: CRC Press. 
Kuhns, D. B., D. A. Long Priel, J. Chu \& K. A. Zarember (2015) Isolation and functional analysis of human neutrophils. Curr Protoc Immunol, 111, 723 1-16.

Kusai, N. A., M. Mior Zakuan Azmi, S. Zulkifly, M. T. Yusof \& N. A. I. Mohd Zainudin (2016) Morphological and molecular characterization of Curvularia and related species associated with leaf spot disease of rice in Peninsular Malaysia. Rendiconti Lincei, 27, 205-214.

Landaeta, M., M. Vial, C. A. Jimenez \& L. G. Debiane (2017) Allergic bronchopulmonary mycosis presenting as a new lung mass. BMJ Case Rep, 2017.

Lanisnik Rizner, T. \& M. H. Wheeler (2003) Melanin biosynthesis in the fungus Curvularia lunata (teleomorph: Cochliobolus lunatus). Can J Microbiol, 49, 110-9.

Latge, J. P. (1999) Aspergillus fumigatus and aspergillosis. Clin Microbiol Rev, 12, 310-50.

Lau, D., H. Mollnau, J. P. Eiserich, B. A. Freeman, A. Daiber, U. M. Gehling, J. Brummer, V. Rudolph, T. Munzel, T. Heitzer, T. Meinertz \& S. Baldus (2005) Myeloperoxidase mediates neutrophil activation by association with CD11b/CD18 integrins. Proc Natl Acad Sci U S A, 102, 431-6.

Laupeze, B., O. Fardel, M. Onno, N. Bertho, B. Drenou, R. Fauchet \& L. Amiot (1999) Differential expression of major histocompatibility complex class Ia, Ib, and II molecules on monocytes-derived dendritic and macrophagic cells. Hum Immunol, 60, $591-7$.

Lauvau, G., P. Loke \& T. M. Hohl (2015) Monocyte-mediated defense against bacteria, fungi, and parasites. Semin Immunol, 27, 397-409.

Le, T., L. Leung, W. L. Carroll \& K. R. Schibler (1997) Regulation of interleukin-10 gene expression: possible mechanisms accounting for its upregulation and for maturational differences in its expression by blood mononuclear cells. Blood, 89, 4112-9.

Lefkowitz, D. L., E. Roberts, K. Grattendick, C. Schwab, R. Stuart, J. Lincoln, R. C. Allen, N. Moguilevsky, A. Bollen \& S. S. Lefkowitz (2000) The endothelium and cytokine secretion: the role of peroxidases as immunoregulators. Cell Immunol, 202, 23-30.

Libby, R. D., J. A. Thomas, L. W. Kaiser \& L. P. Hager (1982) Chloroperoxidase halogenation reactions. Chemical versus enzymic halogenating intermediates. $J$ Biol Chem, 257, 5030-7.

Liu, T., L. Liu, X. Jiang, X. Huang \& J. Chen (2009) A new furanoid toxin produced by Curvularia lunata, the causal agent of maize Curvularia leaf spot. Canadian Journal of Plant Pathology, 31, 22-27.

Liu, T., Y. Wang, B. Ma, J. Hou, Y. Jin, Y. Zhang, X. Ke, L. Tai, Y. Zuo \& K. Dey (2016) $\mathrm{Clg} 2 \mathrm{p}$ interacts with $\mathrm{Clf}$ and ClUrase to regulate appressorium formation, pathogenicity and conidial morphology in Curvularia lunata. Sci Rep, 6, 24047.

Liu, T., S. Xu, L. Liu, F. Zhou, J. Hou \& J. Chen (2011) Cloning and characteristics of Brn1 gene in Curvularia lunata causing leaf spot in maize. European journal of plant pathology, 131, 211-219.

Liu, T. N., T. M'Timkulu, J. Geigert, B. Wolf, S. L. Neidleman, D. Silva \& J. C. HunterCevera (1987) Isolation and characterization of a novel nonheme chloroperoxidase. Biochem Biophys Res Commun, 142, 329-33.

Livak, K. J. \& T. D. Schmittgen (2001) Analysis of relative gene expression data using realtime quantitative PCR and the 2(-Delta Delta C(T)) Method. Methods, 25, 402-8.

Loeffler, J., Z. Haddad, M. Bonin, N. Romeike, M. Mezger, U. Schumacher, M. Kapp, F. Gebhardt, G. U. Grigoleit, S. Stevanovic, H. Einsele \& H. Hebart (2009) Interaction 
analyses of human monocytes co-cultured with different forms of Aspergillus fumigatus. J Med Microbiol, 58, 49-58.

Luther, K., A. Torosantucci, A. A. Brakhage, J. Heesemann \& F. Ebel (2007) Phagocytosis of Aspergillus fumigatus conidia by murine macrophages involves recognition by the dectin-1 beta-glucan receptor and Toll-like receptor 2. Cell Microbiol, 9, 368-81.

Macedo-Ribeiro, S., W. Hemrika, R. Renirie, R. Wever \& A. Messerschmidt (1999) X-ray crystal structures of active site mutants of the vanadium-containing chloroperoxidase from the fungus Curvularia inaequalis. J Biol Inorg Chem, 4, 209-19.

Madrid, H., K. C. da Cunha, J. Gene, J. Dijksterhuis, J. Cano, D. A. Sutton, J. Guarro \& P. W. Crous (2014) Novel Curvularia species from clinical specimens. Persoonia, 33, 48-60.

Manamgoda, D. S., L. Cai, A. H. Bahkali, E. Chukeatirote \& K. D. Hyde (2011) Cochliobolus: an overview and current status of species. Fungal Diversity, 51, 3-42.

Manamgoda, D. S., L. Cai, E. H. C. McKenzie, P. W. Crous, H. Madrid, E. Chukeatirote, R. G. Shivas, Y. P. Tan \& K. D. Hyde (2012) A phylogenetic and taxonomic reevaluation of the Bipolaris - Cochliobolus - Curvularia Complex. Fungal Diversity, $56,131-144$.

Manzoli, T. F., E. J. Troster, J. F. Ferranti \& M. M. Sales (2016) Prolonged suppression of monocytic human leukocyte antigen-DR expression correlates with mortality in pediatric septic patients in a pediatric tertiary Intensive Care Unit. J Crit Care, 33, 84-9.

Marr, K. A., M. Koudadoust, M. Black \& S. A. Balajee (2001) Early events in macrophage killing of Aspergillus fumigatus conidia: new flow cytometric viability assay. Clin Diagn Lab Immunol, 8, 1240-7.

Martinez, F. O. \& S. Gordon (2014) The M1 and M2 paradigm of macrophage activation: time for reassessment. F1000Prime Rep, 6, 13.

Martinez, F. O., L. Helming, R. Milde, A. Varin, B. N. Melgert, C. Draijer, B. Thomas, M. Fabbri, A. Crawshaw, L. P. Ho, N. H. Ten Hacken, V. Cobos Jimenez, N. A. Kootstra, J. Hamann, D. R. Greaves, M. Locati, A. Mantovani \& S. Gordon (2013) Genetic programs expressed in resting and IL-4 alternatively activated mouse and human macrophages: similarities and differences. Blood, 121, e57-69.

McCormick, A., L. Heesemann, J. Wagener, V. Marcos, D. Hartl, J. Loeffler, J. Heesemann \& F. Ebel (2010) NETs formed by human neutrophils inhibit growth of the pathogenic mold Aspergillus fumigatus. Microbes Infect, 12, 928-36.

McGaha, T. L., Y. Chen, B. Ravishankar, N. van Rooijen \& M. C. Karlsson (2011) Marginal zone macrophages suppress innate and adaptive immunity to apoptotic cells in the spleen. Blood, 117, 5403-12.

McGinnis, M. R. (1983) Chromoblastomycosis and phaeohyphomycosis: new concepts, diagnosis, and mycology. J Am Acad Dermatol, 8, 1-16.

Messerschmidt, A., L. Prade \& R. Wever (1997) Implications for the catalytic mechanism of the vanadium-containing enzyme chloroperoxidase from the fungus Curvularia inaequalis by X-ray structures of the native and peroxide form. Biol Chem, 378, 30915.

Messerschmidt, A. \& R. Wever (1996) X-ray structure of a vanadium-containing enzyme: chloroperoxidase from the fungus Curvularia inaequalis. Proc Natl Acad Sci U S A, 93, 392-6. 
Mestas, J. \& C. C. Hughes (2004) Of mice and not men: differences between mouse and human immunology. J Immunol, 172, 2731-8.

Metzler, K. D., T. A. Fuchs, W. M. Nauseef, D. Reumaux, J. Roesler, I. Schulze, V. Wahn, V. Papayannopoulos \& A. Zychlinsky (2011) Myeloperoxidase is required for neutrophil extracellular trap formation: implications for innate immunity. Blood, 117, 953-9.

Miyamoto, S., G. R. Martinez, D. Rettori, O. Augusto, M. H. Medeiros \& P. Di Mascio (2006) Linoleic acid hydroperoxide reacts with hypochlorous acid, generating peroxyl radical intermediates and singlet molecular oxygen. Proc Natl Acad Sci US A, 103, 293-8.

Moody, M. N., J. Tschen \& M. Mesko (2012) Cutaneous Curvularia infection of the forearm. Cutis, 89, 65-8.

Morris, D. R. \& L. P. Hager (1966) Chloroperoxidase. I. Isolation and properties of the crystalline glycoprotein. J Biol Chem, 241, 1763-8.

Mullins, J., R. Harvey \& A. Seaton (1976) Sources and incidence of airborne Aspergillus fumigatus (Fres). Clin Allergy, 6, 209-17.

Murphy, K., P. Travers, M. Walport \& C. Janeway. 2008. Janeway's immunobiology. New York : Garland Science,.

Murray, P. J. \& T. A. Wynn (2011) Protective and pathogenic functions of macrophage subsets. Nat Rev Immunol, 11, 723-37.

Nagy, E., L. Kredics, Z. Antal \& T. Papp (2004) Molecular diagnosis, epidemiology and taxonomy of emerging medically important filamentous fungi. Reviews in Medical Microbiology, 15, 153-162.

Nair, S., N. Kukreja, B. P. Singh \& N. Arora (2011) Identification of B cell epitopes of alcohol dehydrogenase allergen of Curvularia lunata. PLoS One, 6, e20020.

Nau, G. J., J. F. Richmond, A. Schlesinger, E. G. Jennings, E. S. Lander \& R. A. Young (2002) Human macrophage activation programs induced by bacterial pathogens. Proc Natl Acad Sci U S A, 99, 1503-8.

Netea, M. G., L. A. Joosten, J. W. van der Meer, B. J. Kullberg \& F. L. van de Veerdonk (2015) Immune defence against Candida fungal infections. Nat Rev Immunol, 15, 630-42.

Nguyen, G. T., E. R. Green \& J. Mecsas (2017) Neutrophils to the ROScue: Mechanisms of NADPH oxidase activation and bacterial resistance. Front Cell Infect Microbiol, 7, 373.

Noda Milla, J. R., J. Jagirdar, S. Levine \& J. Peters. 2015. Mold In The Middle. In A83 GREAT CASES: CLINICAL, RADIOLOGIC AND PATHOLOGIC CORRELATIONS BY MASTER CLINICIANS. Am J Respir Crit Care Med.

Odobasic, D., A. R. Kitching, Y. Yang, K. M. O'Sullivan, R. C. Muljadi, K. L. Edgtton, D. S. Tan, S. A. Summers, E. F. Morand \& S. R. Holdsworth (2013) Neutrophil myeloperoxidase regulates T-cell-driven tissue inflammation in mice by inhibiting dendritic cell function. Blood, 121, 4195-204.

Ohm, R. A., N. Feau, B. Henrissat, C. L. Schoch, B. A. Horwitz, K. W. Barry, B. J. Condon, A. C. Copeland, B. Dhillon, F. Glaser, C. N. Hesse, I. Kosti, K. LaButti, E. A. Lindquist, S. Lucas, A. A. Salamov, R. E. Bradshaw, L. Ciuffetti, R. C. Hamelin, G. H. Kema, C. Lawrence, J. A. Scott, J. W. Spatafora, B. G. Turgeon, P. J. de Wit, S. Zhong, S. B. Goodwin \& I. V. Grigoriev (2012) Diverse lifestyles and strategies of 
plant pathogenesis encoded in the genomes of eighteen Dothideomycetes fungi. PLoS Pathog, 8, e1003037.

Ouyang, W., S. Rutz, N. K. Crellin, P. A. Valdez \& S. G. Hymowitz (2011) Regulation and functions of the IL-10 family of cytokines in inflammation and disease. Annu Rev Immunol, 29, 71-109.

Pagni, M., V. Ioannidis, L. Cerutti, M. Zahn-Zabal, C. V. Jongeneel, J. Hau, O. Martin, D. Kuznetsov \& L. Falquet (2007) MyHits: improvements to an interactive resource for analyzing protein sequences. Nucleic Acids Res, 35, W433-7.

Palojarvi, A., J. Petaja, S. Siitonen, C. Janer \& S. Andersson (2013) Low monocyte HLADR expression as an indicator of immunodepression in very low birth weight infants. Pediatr Res, 73, 469-75.

Papayannopoulos, V. \& A. Zychlinsky (2009) NETs: a new strategy for using old weapons. Trends Immunol, 30, 513-21.

Parameswaran, N. \& S. Patial (2010) Tumor necrosis factor-alpha signaling in macrophages. Crit Rev Eukaryot Gene Expr, 20, 87-103.

Paredes, K., J. Capilla, D. A. Sutton, E. Mayayo, A. W. Fothergill \& J. Guarro (2013) Virulence of Curvularia in a murine model. Mycoses, 56, 512-5.

Park-Min, K. H., T. T. Antoniv \& L. B. Ivashkiv (2005) Regulation of macrophage phenotype by long-term exposure to IL-10. Immunobiology, 210, 77-86.

Park, S. J. \& B. Mehrad (2009) Innate immunity to Aspergillus species. Clin Microbiol Rev, 22, 535-51.

Parker, H., M. Dragunow, M. B. Hampton, A. J. Kettle \& C. C. Winterbourn (2012) Requirements for NADPH oxidase and myeloperoxidase in neutrophil extracellular trap formation differ depending on the stimulus. J Leukoc Biol, 92, 841-9.

Pfaller, M. A. \& D. J. Diekema (2004) Rare and emerging opportunistic fungal pathogens: concern for resistance beyond Candida albicans and Aspergillus fumigatus. J Clin Microbiol, 42, 4419-31.

Philippe, B., O. Ibrahim-Granet, M. C. Prevost, M. A. Gougerot-Pocidalo, M. Sanchez Perez, A. Van der Meeren \& J. P. Latge (2003) Killing of Aspergillus fumigatus by alveolar macrophages is mediated by reactive oxidant intermediates. Infect Immun, 71, 303442.

Phillips, R. J., M. Lutz \& B. Premack (2005) Differential signaling mechanisms regulate expression of $\mathrm{CC}$ chemokine receptor-2 during monocyte maturation. J Inflamm (Lond), 2, 14.

Plantinga, M., M. Guilliams, M. Vanheerswynghels, K. Deswarte, F. Branco-Madeira, W. Toussaint, L. Vanhoutte, K. Neyt, N. Killeen, B. Malissen, H. Hammad \& B. N. Lambrecht (2013) Conventional and monocyte-derived CD11b(+) dendritic cells initiate and maintain $\mathrm{T}$ helper 2 cell-mediated immunity to house dust mite allergen. Immunity, 38, 322-35.

Plonka, P. M. \& M. Grabacka (2006) Melanin synthesis in microorganisms--biotechnological and medical aspects. Acta Biochim Pol, 53, 429-43.

Poradzka, A., M. Jasik, W. Karnafel \& P. Fiedor (2013) Clinical aspects of fungal infections in diabetes. Acta Pol Pharm, 70, 587-96.

Posteraro, B., E. Scarano, M. La Sorda, R. Torelli, E. De Corso, A. Mule, G. Paludetti, G. Fadda \& M. Sanguinetti (2010) Eosinophilic fungal rhinosinusitis due to the unusual pathogen Curvularia inaequalis. Mycoses, 53, 84-8. 
Raffa, R. B., N. S. Eltoukhy \& K. F. Raffa (2012) Implications of climate change (global warming) for the healthcare system. J Clin Pharm Ther, 37, 502-4.

Renirie, R., C. Pierlot, R. Wever \& J.-M. Aubry (2009) Singlet oxygenation in microemulsion catalysed by vanadium chloroperoxidase. Journal of Molecular Catalysis B: Enzymatic, 56, 259-264.

Revankar, S. G. (2007) Dematiaceous fungi. Mycoses, 50, 91-101.

Revankar, S. G. \& D. A. Sutton (2010) Melanized fungi in human disease. Clin Microbiol Rev, 23, 884-928.

Rivera, A., T. M. Hohl, N. Collins, I. Leiner, A. Gallegos, S. Saijo, J. W. Coward, Y. Iwakura \& E. G. Pamer (2011) Dectin-1 diversifies Aspergillus fumigatus-specific T cell responses by inhibiting T helper type 1 CD4 T cell differentiation. $J$ Exp Med, 208, 369-81.

Roebuck, K. A. (1999) Regulation of interleukin-8 gene expression. J Interferon Cytokine Res, 19, 429-38.

Roilides, E. (2016) Emerging fungi causing human infection: new or better identified? Clin Microbiol Infect, 22, 660-1.

Roilides, E., M. Simitsopoulou, A. Katragkou \& T. J. Walsh (2009) Host immune response against Scedosporium species. Medical Mycology, 47, 433-440.

Romani, L. (2004) Immunity to fungal infections. Nat Rev Immunol, 4, 1-23.

Romani, L., P. Puccetti, A. Mencacci, E. Cenci, R. Spaccapelo, L. Tonnetti, U. Grohmann \& F. Bistoni (1994) Neutralization of IL-10 up-regulates nitric oxide production and protects susceptible mice from challenge with Candida albicans. J Immunol, 152, 3514-21.

Romero-Martinez, R., M. Wheeler, A. Guerrero-Plata, G. Rico \& H. Torres-Guerrero (2000) Biosynthesis and functions of melanin in Sporothrix schenckii. Infect Immun, 68, 3696-703.

Rosowski, E. E., N. Raffa, B. P. Knox, N. Golenberg, N. P. Keller \& A. Huttenlocher (2018) Macrophages inhibit Aspergillus fumigatus germination and neutrophil-mediated fungal killing. PLoS Pathog, 14, e1007229.

Sabroe, I., L. R. Prince, E. C. Jones, M. J. Horsburgh, S. J. Foster, S. N. Vogel, S. K. Dower $\&$ M. K. Whyte (2003) Selective roles for Toll-like receptor (TLR)2 and TLR4 in the regulation of neutrophil activation and life span. J Immunol, 170, 5268-75.

Schaffner, A., H. Douglas \& A. Braude (1982) Selective protection against conidia by mononuclear and against mycelia by polymorphonuclear phagocytes in resistance to Aspergillus. Observations on these two lines of defense in vivo and in vitro with human and mouse phagocytes. J Clin Invest, 69, 617-31.

Schnitzler, N., H. Peltroche-Llacsahuanga, N. Bestier, J. Zundorf, R. Lutticken \& G. Haase (1999) Effect of melanin and carotenoids of Exophiala (Wangiella) dermatitidis on phagocytosis, oxidative burst, and killing by human neutrophils. Infect Immun, 67, 94-101.

Schutte, R. J., A. Parisi-Amon \& W. M. Reichert (2009) Cytokine profiling using monocytes/macrophages cultured on common biomaterials with a range of surface chemistries. J Biomed Mater Res A, 88, 128-39.

Schwende, H., E. Fitzke, P. Ambs \& P. Dieter (1996) Differences in the state of differentiation of THP-1 cells induced by phorbol ester and 1,25-dihydroxyvitamin D3. J Leukoc Biol, 59, 555-61. 
Seger, R. A. (2008) Modern management of chronic granulomatous disease. Br J Haematol, 140, 255-66.

Serbina, N. V., M. Cherny, C. Shi, S. A. Bleau, N. H. Collins, J. W. Young \& E. G. Pamer (2009) Distinct responses of human monocyte subsets to Aspergillus fumigatus conidia. J Immunol, 183, 2678-87.

Sharma, V., B. P. Singh \& N. Arora (2011) Cur 1 3, a major allergen of Curvularia lunataderived short synthetic peptides, shows promise for successful immunotherapy. Am J Respir Cell Mol Biol, 45, 1178-84.

Shi, C. \& E. G. Pamer (2011) Monocyte recruitment during infection and inflammation. Nat Rev Immunol, 11, 762-74.

Spriggs, D. R., S. Deutsch \& D. W. Kufe (1992) Genomic structure, induction, and production of TNF-alpha. Immunol Ser, 56, 3-34.

Stappers, M. H. T., A. E. Clark, V. Aimanianda, S. Bidula, D. M. Reid, P. Asamaphan, S. E. Hardison, I. M. Dambuza, I. Valsecchi, B. Kerscher, A. Plato, C. A. Wallace, R. Yuecel, B. Hebecker, M. da Gloria Teixeira Sousa, C. Cunha, Y. Liu, T. Feizi, A. A. Brakhage, K. J. Kwon-Chung, N. A. R. Gow, M. Zanda, M. Piras, C. Zanato, M. Jaeger, M. G. Netea, F. L. van de Veerdonk, J. F. Lacerda, A. Campos, A. Carvalho, J. A. Willment, J. P. Latge \& G. D. Brown (2018) Recognition of DHN-melanin by a C-type lectin receptor is required for immunity to Aspergillus. Nature, 555, 382386.

Stoiber, W., A. Obermayer, P. Steinbacher \& W. D. Krautgartner (2015) The Role of reactive oxygen Species (ROS) in the formation of extracellular traps (ETs) in humans. Biomolecules, 5, 702-23.

Sun, W., T. A. Kadima, M. A. Pickard \& H. B. Dunford (1994) Catalase activity of chloroperoxidase and its interaction with peroxidase activity. Biochem Cell Biol, 72, 321-31.

Taj-Aldeen, S. J., A. A. Hilal \& W. A. Schell (2004) Allergic fungal rhinosinusitis: a report of 8 cases. Am J Otolaryngol, 25, 213-8.

Tamoutounour, S., M. Guilliams, F. Montanana Sanchis, H. Liu, D. Terhorst, C. Malosse, E. Pollet, L. Ardouin, H. Luche, C. Sanchez, M. Dalod, B. Malissen \& S. Henri (2013) Origins and functional specialization of macrophages and of conventional and monocyte-derived dendritic cells in mouse skin. Immunity, 39, 925-38.

Thomas, C. J. \& K. Schroder (2013) Pattern recognition receptor function in neutrophils. Trends Immunol, 34, 317-28.

Thuer, E. \& T. Gabaldon (2017) Comparative transcriptomics of THP-1 monocytes in response to different pathogens. bioRxiv, 155853.

Tokousbalides, M. C. \& H. D. Sisler (1979) Site of inhibition by tricyclazole in the melanin biosynthetic pathway of Verticillium dahliae. Pesticide Biochemistry and Physiology, 11, 64-73.

Torda, A. J. \& P. D. Jones (1997) Necrotizing cutaneous infection caused by Curvularia brachyspora in an immunocompetent host. Australas J Dermatol, 38, 85-7.

Toth, A., E. Zajta, K. Csonka, C. Vagvolgyi, M. G. Netea \& A. Gacser (2017a) Specific pathways mediating inflammasome activation by Candida parapsilosis. Sci Rep, 7, 43129.

Toth, E. J., E. Boros, A. Hoffmann, C. Szebenyi, M. Homa, G. Nagy, C. Vagvolgyi, I. Nagy \& T. Papp (2017b) Interaction of THP-1 Monocytes with Conidia and Hyphae of Different Curvularia Strains. Front Immunol, 8, 1369. 
Tsuchiya, S., M. Yamabe, Y. Yamaguchi, Y. Kobayashi, T. Konno \& K. Tada (1980) Establishment and characterization of a human acute monocytic leukemia cell line (THP-1). Int J Cancer, 26, 171-6.

Urban, C. F., U. Reichard, V. Brinkmann \& A. Zychlinsky (2006) Neutrophil extracellular traps capture and kill Candida albicans yeast and hyphal forms. Cell Microbiol, 8, 668-76.

van der Veen, B. S., M. P. de Winther \& P. Heeringa (2009) Myeloperoxidase: molecular mechanisms of action and their relevance to human health and disease. Antioxid Redox Signal, 11, 2899-937.

van Duin, D., A. Casadevall \& J. D. Nosanchuk (2002) Melanization of Cryptococcus neoformans and Histoplasma capsulatum reduces their susceptibilities to amphotericin B and caspofungin. Antimicrob Agents Chemother, 46, 3394-400.

van Pee, K. H. \& F. Lingens (1985) Purification of bromoperoxidase from Pseudomonas aureofaciens. J Bacteriol, 161, 1171-5.

van Schijndel, J. W., E. G. Vollenbroek \& R. Wever (1993) The chloroperoxidase from the fungus Curvularia inaequalis; a novel vanadium enzyme. Biochim Biophys Acta, 1161, 249-56.

Viola, G. M. \& R. Sutton (2010) Allergic fungal sinusitis complicated by fungal brain mass. Int J Infect Dis, 14 Suppl 3, e299-301.

Vishnoi, S., J. Naidu, S. M. Singh \& R. Vishnoi (2005) Pathogenicity of Curvularia geniculata (C. senegalensis) for albino rats: study of clinical isolate from blood of a cancer patient. Journal de Mycologie Médicale, 15, 97-102.

Wang, J. \& J. Chen (2011) Cloning and functional analysis of Clm1 in Curvularia lunata. Acta Phytopathologica Sinica, 41, 464-472.

Wang, X., R. Zhang, W. Wu, Y. Song, Z. Wan, W. Han \& R. Li (2018) Impaired Specific Antifungal Immunity in CARD9-Deficient Patients with Phaeohyphomycosis. $J$ Invest Dermatol, 138, 607-617.

Wang, Y., P. Aisen \& A. Casadevall (1995) Cryptococcus neoformans melanin and virulence: mechanism of action. Infect Immun, 63, 3131-6.

Warnatsch, A., T. D. Tsourouktsoglou, N. Branzk, Q. Wang, S. Reincke, S. Herbst, M. Gutierrez \& V. Papayannopoulos (2017) Reactive oxygen species localization programs inflammation to clear microbes of different size. Immunity, 46, 421-432.

Warris, A., M. G. Netea, P. E. Verweij, P. Gaustad, B. J. Kullberg, C. M. Weemaes \& T. G. Abrahamsen (2005) Cytokine responses and regulation of interferon-gamma release by human mononuclear cells to Aspergillus fumigatus and other filamentous fungi. Med Mycol, 43, 613-21.

Werner, J. L., A. E. Metz, D. Horn, T. R. Schoeb, M. M. Hewitt, L. M. Schwiebert, I. FaroTrindade, G. D. Brown \& C. Steele (2009) Requisite role for the dectin-1 beta-glucan receptor in pulmonary defense against Aspergillus fumigatus. J Immunol, 182, 493846.

Wever, R. \& W. Hemrika. 2001. In Handbook of Metalloproteins, eds. A. Messerschmidt, R. Huber, K. Wieghardt \& P. T., 1417-1428. Chichester, United Kingdom: John Wiley \& Sons Ltd., .

Wheeler, M. H. \& M. A. Klich (1995) The effects of tricyclazole, pyroquilon, phthalide, and related fungicides on the production of conidial wall pigments by penicillium and Aspergillus species. Pesticide Biochemistry and Physiology, 52, 125-136. 
Whitcomb, M. P., C. D. Jeffries \& R. W. Weise (1981) Curvularia lunata in experimental phaeohyphomycosis. Mycopathologia, 75, 81-8.

Winkelstein, J. A., M. C. Marino, R. B. Johnston, Jr., J. Boyl1e, J. Curnutte, J. I. Gallin, H. L. Malech, S. M. Holland, H. Ochs, P. Quie, R. H. Buckley, C. B. Foster, S. J. Chanock \& H. Dickler (2000) Chronic granulomatous disease. Report on a national registry of 368 patients. Medicine (Baltimore), 79, 155-69.

Winter, J. M. \& B. S. Moore (2009) Exploring the chemistry and biology of vanadiumdependent haloperoxidases. J Biol Chem, 284, 18577-81.

Wong, E. H. \& S. G. Revankar (2016) Dematiaceous Molds. Infect Dis Clin North Am, 30, 165-78.

Xu, S., J. Chen, L. Liu, X. Wang, X. Huang \& Y. Zhai (2007) Proteomics associated with virulence differentiation of Curvularia lunata in maize in China. Journal of Integrative Plant Biology, 49, 487-496.

Yanagihara, M., N. Tachikawa, H. Hanakawa, M. Kawasaki, K. Anzawa, H. Ishizaki, T. Mochizuki, S.-i. Udagawa \& Y. Sato (2010) Tiny keratotic brown lesions on the interdigital web between the toes of a healthy man caused by Curvularia species infection and a review of cutaneous Curvularia infections. Mycoscience, 51, 224-233.

Yang, J., L. Zhang, C. Yu, X. F. Yang \& H. Wang (2014) Monocyte and macrophage differentiation: circulation inflammatory monocyte as biomarker for inflammatory diseases. Biomark Res, 2, 1.

Yona, S., K. W. Kim, Y. Wolf, A. Mildner, D. Varol, M. Breker, D. Strauss-Ayali, S. Viukov, M. Guilliams, A. Misharin, D. A. Hume, H. Perlman, B. Malissen, E. Zelzer \& S. Jung (2013) Fate mapping reveals origins and dynamics of monocytes and tissue macrophages under homeostasis. Immunity, 38, 79-91.

Yost, C. C., M. J. Cody, E. S. Harris, N. L. Thornton, A. M. McInturff, M. L. Martinez, N. B. Chandler, C. K. Rodesch, K. H. Albertine, C. A. Petti, A. S. Weyrich \& G. A. Zimmerman (2009) Impaired neutrophil extracellular trap (NET) formation: a novel innate immune deficiency of human neonates. Blood, 113, 6419-27.

Young, R. C., J. E. Bennett, C. L. Vogel, P. P. Carbone \& V. T. DeVita (1970) Aspergillosis. The spectrum of the disease in 98 patients. Medicine (Baltimore), 49, 147-73.

Yunis, J. J., H. Band, F. Bonneville \& E. J. Yunis (1989) Differential expression of MHC class II antigens in myelomonocytic leukemia cell lines. Blood, 73, 931-7.

Ziegler-Heitbrock, L. (2015) Blood monocytes and their subsets: established features and open questions. Front Immunol, 6, 423.

Ziegler-Heitbrock, L., P. Ancuta, S. Crowe, M. Dalod, V. Grau, D. N. Hart, P. J. Leenen, Y. J. Liu, G. MacPherson, G. J. Randolph, J. Scherberich, J. Schmitz, K. Shortman, S. Sozzani, H. Strobl, M. Zembala, J. M. Austyn \& M. B. Lutz (2010) Nomenclature of monocytes and dendritic cells in blood. Blood, 116, e74-80. 


\section{Köszönetnyilvánítás}

Mindenekelött szeretnék köszönetet mondani Prof. Dr. Vágvölgyi Csabának, a Szegedi Tudományegyetem, Természettudományi és Informatikai Kar, Mikrobiológiai Tanszék vezetőjének, hogy PhD munkámat a tanszéken végezhettem.

Hálával tartozom témavezetőmnek, Dr. Papp Tamásnak, amiért munkámat mindvégig támogatta, megosztotta velem széleskörü szaktudását. Köszönöm belém vetett bizalmát, a rengeteg segítséget, bíztatást.

Köszönet illeti munkatársaimat, Dr. Csernetics Árpádot, Dr. Nyilasi Ildikót, Dr. Csonka Katalint, Dr. Papp Csabát, Zajta Eriket, amiért kérdéseimmel hozzájuk mindig fordulhattam. Köszönöm munkatársaimnak és barátaimnak, Kartali Tündének, Szebenyi Csillának, Bokor Eszternek, Pál Sárának az ötletadó beszélgetéseket, a kísérleteknél nyújtott segítséget, valamint, hogy a legnehezebb pillanatokban is mellettem álltak.

Külön köszönettel tartozom Dr. Boros Évának és Dr. Nagy Istvánnak a THP-1 monociták sejttenyésztésében, az RNS izolálásban és relatív expressziós szint meghatározásban nyújtott nélkülözhetetlen segítségéért, Dr. Varga Mónikának a melanin mérések elvégzéséért, valamint a dolgozat ábráinál nyújtott segítségéért, valamint Petkovits Tamásnak a pásztázó elektronmikroszkópos felvételek készítéséért.

Köszönet illeti Dr. Takó Miklóst és Szabó Katalint a vérvételnél nyújtott segítségükért.

Köszönöm volt szakdolgozómnak, Hoffmann Alexandrának áldozatos munkáját és szorgalmát, amivel nagyban hozzájárult a neutrofil granulocitákkal való interakció vizsgálatánál elért eredményekhez.

Köszönettel tartozom Hargitai Fanninak, Lengyel Boglárkának, Csordás Anitának, Szabó Anikónak az adminisztrációs és hivatalos ügyek intézéséért, Lele Máriának és Deákné Kulcsár Melindának a technikai segítségekért, továbbá minden munkatársamnak a munkám során nyújtott legapróbb segítségekért is.

Köszönöm barátaimnak és páromnak a megértő támogatást és szeretetet.

Végezetül, de nem utolsó sorban hálával és köszönettel tartozom szüleimnek és családomnak, akik egész életem folyamán önzetlenül, feltétel nélkül támogattak, és szeretetükkel mindvégig biztos hátteret nyújtottak.

A kutatás az LP2016-8/2016, GINOP-2.3.2-15-2016-00035, UNKP-17-3-IV-SZTE33 és UNKP-18-3-III-SZTE-28 számú projektek támogatásával valósult meg 


\section{Mellékletek}

1. melléklet: A C. lunata haloperoxidáz szerü fehérjéket kódoló génjeinek szekvenciái. Szürke szín jelöli a promoter és terminális szakaszokat, piros színnel jelölt a kódoló régió, kék szín jelöli a nem transzlálódó régiókat, fekete pedig az intronokat.

\section{HPO1 scaffold_9:696118-697941}

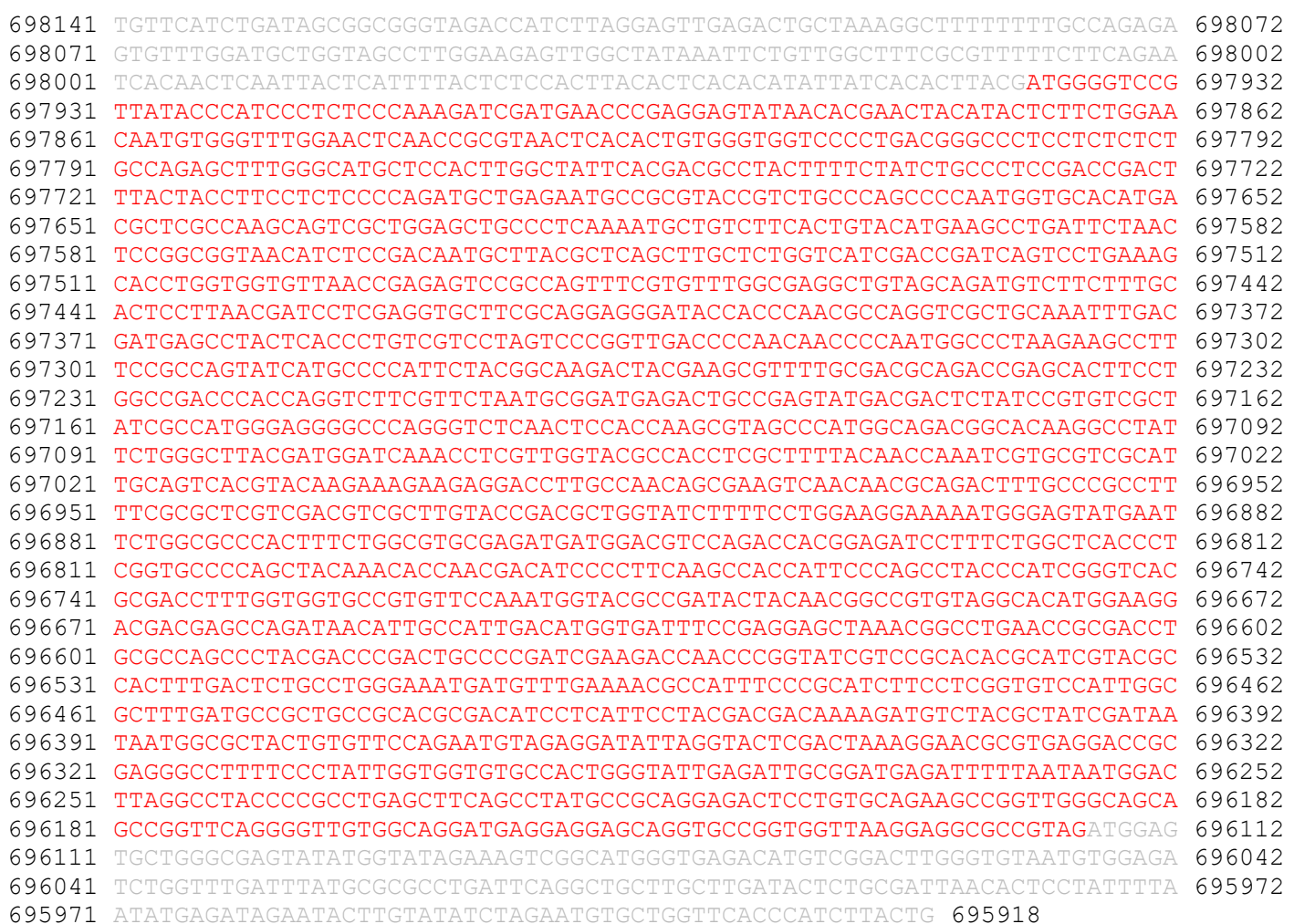

HPO2 scaffold_11:955923-957072

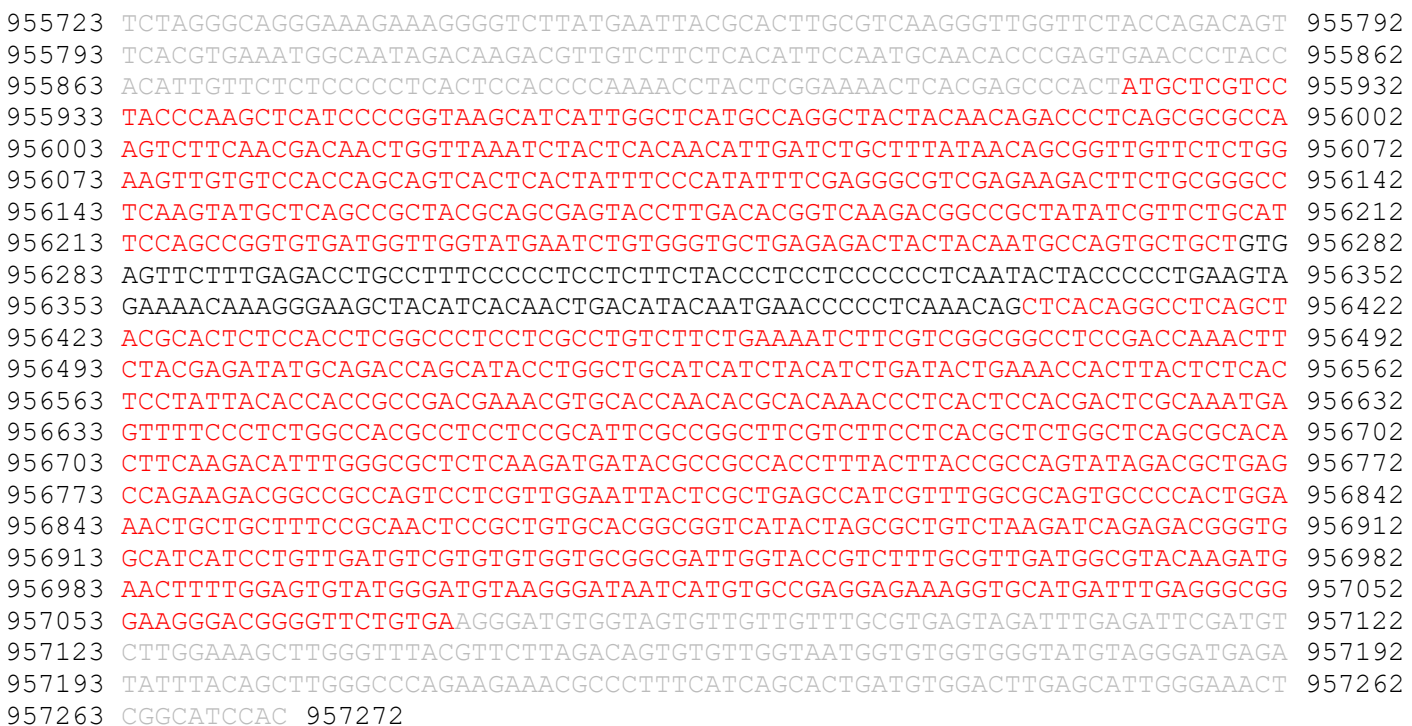




\section{HPO3 scaffold_7:527903-529818}

527703 GTGAGCGTCGCATGTCTGACTCCGTCGTCTGCGGGCTCCCCCGAAATCACTCCGCTGCCGCTGACCGCGC 527772 527773 CCTCACCGCCCGCCTGTGCCTCCCCCCCTCGTGTGCCCAAGGAGAGCACTGCAACTGCGATTGTGGTTGC 527842 527843 GACCAACACAAAAGTTTCATCCATTGTCGTCGGCGGCCGTTTTGGGCCCTGTAGTGCGCCATGGACGAGT 527912 527913 GGACGTCCAAGCAGCTCCCTGAGCGCCTGCCCTTCTCCAAGAAGCGCCTCTCCAAGAAGGTCATCTTCTC 527982 527983 GTGCGTAGAGTCGTCTCGCCCACAGCGCAGTAGATGCTGACCAGCGCAGATATATCGGTGACTATCTGAT 528052 528053 CATCATGTAAGACCACGCCGTCCGGCGCACACGACCTCCTTCCTGGCTTGATTGCAAGGCTGACCACCCT 528122 528123 CCCAGCGTCTTGATGCTCACCTTTGCCATTGTCGACAAGATTCCGCCCTTCCACCAACACTTTTCGCTCG 528192 528193 ACAACTACACCCTACACTATCCCTTTGCTACCCGTGAGCGCGTACCCGTCATATGGCTCTGCGTTTATGT 528262 528263 CGTCCTCGCGCCTGCCGTCATTATTGCTATATACACCATGGTAATCGACGGCCTCTTCTCACACCAAACC 528332 528333 GCCATGCCTGCCAATAGGACCGGCCTCAAGCGTCTCTCGGGGAGATACAGGTTCAAGGATAGGCTGTGGG 528402 528403 AGCTCAACTGCGGTATACTCGGGTTGGGCCTGAGCATTGGTGCTGCCTTTACAATCACCGGGGCTTTGAA 528472 528473 GAATGCTATTGGAAAGCCGCGGCCCGATCTCATCGACCGGCAAGTCAGTCTTTGGCGCGGAGGAGAGCTT 528542 528543 TGACTAACAATCCACAGCTGTCAGGTGGACCCGGCCAAGATCAACCACAACGCCTACGCCCTTCAGACTA 528612 528613 TTGACATTTGCACGCAAACGAACAATTACATTCTGCAGGATGGCTTCAAGAGCTTTCCCTCTGGACATAG 528682 528683 CAGCGGTATGACGTACAGACTCTCTTGCATGCCCACCTGACTGACATCCCAAAGTTTCTTTTGCTGGTCT 528752 528753 GTTTTACCTTTCCATTTACCTCGCAGGAAAACTCCACGTCCTGGACGCCAAGGGTGAAGTCTGGAGGACA 528822 528823 TTTATTGTCATGGTCCCTGCGCTCGGTGCTGCGCTCATCACCGGAACCCGTATCATGGATGCCCGTCATC 528892 528893 ACCCATTCGATGTCATTTCCGGTGCGCTGCTTGGCATACTTGTAGCATGGGGCTCGTACCGCCAATACTT 528962 528963 TCCTCCTGTTTCCGAGACCTGGCGCAAGGGACGCGCATATCCCATTCGCGCTTGGGGCAAAGCCTCGCGC 529032 529033 GCGCCGCCTCATGGTGCCCTGCTTGCCGAAGATGACATCCGACAGCTACAAGAAATCAACAAACCAGTAG 529102 529103 ATGAGGAGCGCGGGGAAGCTTCGGGTTATTCTGCCGCGGCTACGGTCCCTGCAGACGGTGAAATTGGAAA 529172 529173 CAATGTGTTCCGCCAACAAATCCATAACTCTCAGCGGAGGCGCCAAGAGTCCGGATCTCACTATGGCGTG 529242 529243 GGCCGAAGTGACACAGGCGCTTCGAGCAACTACCGCACCGAGACCATGAATTCAGGCATCTCCTCGAAGG 529312 529313 TCAACAGATATACTAATCAGCTGCCATCCACCAATCCTTTCGCCGCTGATGTCGCACGCCAACGCCAACT 529382 529383 GGATACCTATGATTATTCATCCTCGGAAGACGACGGCAACTACGAGCTCCAACCCAGGGCGGGCGTTTAC 529452 529453 AACCCAGTGTCTGGCACACTCACGGATACAGGATACCATCCACCCACGGGTATCTCCCCAGTTCCTACAC 529522 529523 CACCTCCTCAGGCAAACACCATTCTACATAACCAGGCGACGACCATGTCTCCGACAGGCGACCTTTCTGA 529592 529593 TCGAAGAGAAGTTCCACCCATGCCTCCTCCACATGGTGCGAGCAACTTGTCTCAGCAAATATGAAGTCGG 529662 529663 TTCAAGGTGTACGATCATGTGTGAGTGACGTTGTTTTTTTGGTGGAAGCAAGTGCATTTCTGGAAAATAC 529732 529733 CCGCATCCTCGTTACTCGGCAGATTTTGGTGTGTGCCGATGAGCGTATGAGAAGCCATTACGGTTAAGAC 529802 529803 GAGCCTCATGTATCACGCCCTTGGCCAGGAGCAAGGAGTTGAGTGGAATTGGGAACTATGACAGGAACCA 529872 529873 GATTTTCCTTAGAGAAAGGAATCAACACGGTGCCATGGATTTGGCACATAACTGAATCGAATTAC 529942 529943 CTGTAATCTCACTTGACGTCTATGTATCCACGTGTGGTGATAAATCCCTAGATTGGCATATCAGTGTTG 530012 530013 CCCTGC 530018

\section{HPO4 scaffold_10:741379-743059}

741179 AATGGGCATGTGGGAGCCCAGGGCCAGCACCGCGCCAGGGCTGCAAACGAGATTGCAGCCTGCATGTGCC 741248 741249 CTCGGCCTAGCCCGCCCTCAGTTAGCCGCTCACGTCGCGCGCCTCAGCCATCCGAAGCTTCCTTCCCCTA 741318 741319 CAGCGCCTCGTCTTCATAATCCCTAGTCCGCCCTCTTCCGTCCTGTCCTGTCTCGCCCGCCCTCACCTG 741388 741389 CTCGCCCGACTCTCTTCAAAACAAAAAGTAGTCCCCAACAGAGGCCCGACGCAAACGCCCTCCACCCCGT 741458 741459 GGTTGCTGTTGCTGTTGCTGCTGTAGCTGTGGTTGTGTACTTGCTTCTCTTCTTCTGCTCGTCTGCCTAC 741528 741529 TCCCGACCGCCGCCTCCGGTCGCCTGCTCCCGTCGCCGTTCCCCCCACGCGACCCCCATATATATTCACC 741598 741599 ATGACCAACAAGAGCTATCTCGCCTTCCTCGACAGCACCACGGCCTCGGACATGCTCTCGCGCTCCTCGG 741668 741669 TGCCAGGCCTCTCGGCCCTGCCCAGCCTGATCCCCCACCGCGTCCGCAGAAAGTGGAGGGCCACCCGGTC 741738 741739 GCGCATACGTGGGCGCCAGTCGCCAACCTCGTCCATTGCCTCGCTCGAGACGTCCTTCTCGCCCTCGGAT 741808 741809 ACCCTGCGCTCCCTGCGCTCCCACTCGTGGTCCATATACGACGCCCAGTACCTCTTTCTCGCCATTGTCG 741878 741879 CCATCTTCTCCCTGTCCGTCAGCGAGTCTCCTGGCCCATTTGCAAAGACATTTATTGCAACCCTGCTTAT 741948 741949 GACGGGCTTGTGTCTGCCTATTACCCGCCAATTCTTGCTCCCATTGCTTCCAACTCTTACCTGGCTATTC 742018 742019 CTTTTCTCGAGCTGCAAGTACGTACTCTGCGCTATGTCTGTCCATGAACTAGAAAAAATACTAACAATTC 742088 742089 CGCCAGATACATCTCCCCAGAATACCGACCTGCTATCTGGGTCCGCGTCCTCCCCGCTCTCGAGAACATT 742158 742159 CTTTATGGCTCAAACCTGAGCAACATTCTCTCCGCCAACAAGCACACAGTCCTCGATATCCTTGCTTGGC 742228

742229 TGCCCTACGGAGTGGTCCACTATGTATCGCCCGTCATTGTTAGCGGATGCATGTTCATCTGGGGCCCTCC 742298 742299 GGGAACCCTCCCCATCTGGGCTCGCGCCTTTGGCTACATGAACATCACCGCCGTCCTGATCCAGATTGTT 742368 742369 TTCCCCTGCTCCCCGCCATGGTACGAGAACACATACGGACTGGCGCCCGCTACCTACAGCGTCAAGGGAG 742438 742439 ACGCTGCAGGACTCAAGGCCATTGACGCCCTCACCGGCATCGATATCTACACATCTGCCTTCTTGGGCTC 742508 742509 ACCCATGGTTTTTGGTGCTTTCCCTTCCCTGCATTCCGGATGGGCTACTCTGGAGACGCTCTTCATGGGC 742578 742579 CATGTTTTCCCTAGGCTCTTCCCTGTATATGTATTCTACACCATGTGGCTTTGGTGGTCTACCATGTACT 742648 742649 TTTCTCACCACTACGCCGTCGACCTGGTTGCTGGCAGTCTCCGTAAGTTACTCAACTTCCCATTTCCACC 742718 742719 AATGTCGTGGCTAACCATGTCTCAGTCGCTGGTGTCTGCTACTTCTTCGGCCGTGCCAACTTCCTGCCCC 742788 742789 GCCCTCAACCCGACAAGGAGTTCCGATGGGACTACGACTATGTCGAGATTGGTGACCCCGCAGATGGTGC 742858 742859 TGGCTTCAGCATGCTCGACATCTACGACGAGTTCCCATCCCACTCCGACTCTGAAGACTGGGCCAGTGGT 742928 742929 TCCTCTTCATCCTACTCTACCGGCGGCCGAAGCCCAATTGGCGCCCGTTCGCCAACTGACGACAACCAGA 742998 742999 GCCTCTGGGACGGAGACACAGTCGGATCTGATACCGAGCACACCCTCCGCAAAGACTAGACGCCACGCCT 743068 743069 ACCTACATCTCTCACTCTCCAAACTTACACCCATCTCCAAATTCGCACATCACCTAATCACCCCTCCAGG 743138 
743139 TGACGGCCTTTTACGACCTATGCATTGGATCGGAGTTTTTTTCTTGTTTGCGAAGCATTTCAGCGTTCCA 743208

743209 TGGACATACACATGGGCATAACGGCATAGAAATCGCGCGCGTCTCTACCGA 743259

\section{HPO5 scaffold 23:159813-161445}

159613 GCTGAACCACCGAAACAGCACAATCTCTGTGCAAAGCCGGTTTTCTGCTTCGACCCGACACCATGGGATT 159682 159683 GTCTGTGCGACGGGGATGATGTCGAATGACGACGTCTACTACAAACCTTTCAAACGCTGAGGGGTGTTTG 159752 159753 CTGGAGTATAAGGGACACACCGCCGTGTGTTTGACTTGCTCTTGTCCAGCAACACTCTCAGTCCTCTCTT 159822 159823 TCCTCCACTCTAGATACTTGCTGGCTCCCCCGAGCTGACTGGGTGCCCATACGTCATTCACAGTTCGGTA 159892 159893 TACTTGCCTCGTCTGACAACCAGAACCAACACCATCGTCATGGGCTTCTTCAACAAGCGCAACACGACGC 159962 159963 CCGTCGCTGCAGACACTGCTGCTGCAACCGGCACTCACAGGGAAAAGAGACCAAGGCGCCACTCCAAATC 160032 160033 TCACCCGTCGTCGTACAACACCAGGCCCAGCTTTGGACAATGGCTCAAGGCAACTTGGCTCGACATTGTG 160102 160103 ACCATGGCCGCTATGGGCGCCGTCGGTCTCGGTGTATACATGGCTGACCCAGCCCCCAGCCGCAGCTTTC 160172 160173 CAGTCATCTTCCAGGATGGCGAGATTGTCTATCCCGAGTTCGCCTACCCCCTGCGCAACGAAATCGTCCC 160242 160243 CATCTGGGCTGCCGCCCTCATGGCCTTTTTCATTCCTTTTGCCGTCTTCCTCATTGTTCAGATCCGCGCC 160312 160313 CGCAGCTTCTGGGACATCAACAACGCCACCATTGGCCTACTCTACTCCCTCATCACCGCTGCTGTATTCC 160382 160383 AAGTCTTCATCAAGTGGCTCATTGGTGGACTTCGCCCTCACTTCCTCGCCGTCTGCAAGCCTGTCATCCC 160452 160453 CGCCGACATTCTCGCCAGCGTTGGCAATTCAGACAACGGCGTCGAGGCAGGCAGCGCCTATGGCAACGTT 160522 160523 GCCAATGGTTACAGACAAATCATGTTTGACAGGAGCATCTGCACCGGTGATCGCAACGAGATCAACGACA 160592 160593 GTCTTGAGTCCATGCCGTCCGGCCACACTACTGCTGCTTTTGCCGGCTTCGTCTTCCTCTACCTGTACCT 160662 160663 CAACGCAAAGCTCAAGGTCTTTGCAAACTACCACCCCGCAATGTGGAAGATCATTGCATTGTACGCTCCT 160732 160733 ATTCTCGGTGCCTGTTTGATTGGCGGTGCCCTCACCATTGACGAATACCACAACTGGGTATGTACTGTTT 160802 160803 TACTTTATCAGAAATACATGATACTAACATCAGAAATCAGTACGACATCCTCGCTGGCGCAGTGATTGGT 160872 160873 ACCATGATGGCATTCAGCGCCTACCGCATGACATACGCCTCCATCTGGGACTTCCGCTTCAACCACATCC 160942 160943 CTCTTCTACGCCACACTCCATTTATCTACGGCGCCGGCCCTAGCTCATTTGACGGCTTCCACGACGTCGT 161012 161013 CTTTACCCGCAAGGCTGGCTGGGGCACCCATGAGGGAGGTAGCTGGGGTGGCGCGCCTTTTGATGCTGCT 161082 161083 GATGGCCCCAGGGGCTCCATGATGCCACAGGCAGAGGGCCCTGCTGGTTCCCACGTGTCTAGGAAGCCTG 161152 161153 TTGGAACTGGTTCCAGGGGAGAGCACATGGTTTAGAGGCTGAAATCATTTCACTCTGAGTGAAGAATGGA 161222 161223 GGGAGCGAGAGTGTGATTTTCCAGAGGCTCAGTGGTTTTTTTTTCACTGTCCTGGTACTACCATTGGGAT 161292 161293 TGGCTTTACGTTTTTTTCCTAATACCGAGATTTTATACCCGTGTATACCTAATTTGTATCATTAATGACG 161362 161363 GCGACGATACCAACGGGCGTTTTTTTTACTTTTTCTCTTGTATAATTAGCTGAACGGATAATATCACTTT 161432 161433 GATGTTCTACTACAATCCA GCCATGATAGTCGAAGGCCTGGCCATTCTGTGTGATTTAAAGCGTAGATGA 161502 161503 GAATCTATCCAACGATACACTAATCCTTAGTAACCCTTCTCTGAGTCGATTTGTGGAATACCAGCGTGTA 161572 161573 ACTAGAATCAATTTATTTCCCAGCTGGAATTAAATAATCACACGTACTTAACTCCTAGTTTACCGCACAG 161642 161643 ATG 161645

\section{HPO6 scaffold_2:197552-199940}

200140 GCGATCAGTGGGAATTCTGTTTAGTGTTACCATCATAAATTCTCAGAGTATGCCTGTGGCTGTTGTTTCC 200071 200070 TACGCTTCTTCTAGTACCGTTCACTGAAACAACAGAATTACACATCCAGGACTGAAGTTMACTAAGGCGA 200001 200000 ATGCACATGTAGCTTCGGAAGGTGGAGCCGTAGCACCTAAATATAACCACGATACTACATATGGCATTCT 199931 199930 TCGTGTCTATAGATATCCTAGATCAGAATATCAATATGGAAAAGTATACTGAGCTCTCTGCAAATGCACT 199861 199860 CTTCAATGTCAATGGCATCGTCGCCGTCATCACGGGCGGCGGATCAGGTAGTCTACTCGGGATCGACAAG 199791 199790 GCCGAATCTGGCACTGAAACTCACAGGTATCGGACTGATGATGACCAAAGCGCTGGCTGCAAATGGTGCG 199721 199720 CACCGCATCTACATCATCGGCCGTAGAGAGGATGTCCTACTTGAAGCGGCCGCCAGCATCGACCCAAAAG 199651 199650 TCGTTATTCCTCTACCAGGAGACATAACCTCTCAAGACACACTGCTTGACATGGCAGCAAAAGTTGAATC 199581 199580 GGAAACAGGCTACGTCAATCTCGTCATTGCAAACGCCGGCATCATGGGCCCAAGACCACTCAAAGCCGCC 199511 199510 CCGGGTAGTCCCATACCCTCAATCAGCGAGTACCGAGCACACGCCCTACAGACACCCATGCATGATTTCA 199441 199440 CGCAAACTTACGCTGTAAATGCGACAGGCGTTTACTACACAGCTCTAGCTTTCCTCAACCTCCTCGATGC 199371 199370 TGGCAACACCAAAGGCAACCTGGGAGCCGACATGCGCTCCCAAATCATTGCTACCTCCAGCATCGGCGGC 199301 199300 TTCTCGCGCCTCGCAGGCGCCTCATTTGCATACAACAGCAGCAAAGCCGCAGTCACGCACATGATGAAGA 199231 199230 TGATGGCTACATCGTTCGCTCCATATCGCATCCGCTGCAACGTGCTGGCCCCAGGCATCTTTCCGTCTGA 199161 199160 CATCACGACTGGCATCATCGGGAACTTGGATCCGGGGCAGAGCGGTAGCGTGAGCAAGGAGGTGATACCA 199091 199090 GCGGAGAGGACAGGCAATGAGAGAGATCTTGCCGGGGCGGTGCTATGGATGGCGGGGTTGGCGGGGGCGT 199021 199020 ATCTGAATGGAAGTGTGATTGTGGTGGATGGAGGGAGATTGAGTATGCTACCGTCGACGTATTGACAATC 198951 198950 TTCTGTGCGGTTTTACCGAGCCATCGCTATTGAGTCAATAGCAATCGGAGGACAGATTACAAAGAGTAAA 198881 198880 TATATACATTGTAGTCTTAGAATAGGTATGACAACTAGACTAGTAGTCCATTACAGACGCATGCCTATGA 198811 198810 CGCAGCATTCGCGCGCTAGCGGCAGCGGCCCGTGCCATGCCTGCCGCTGCGGAGTTGAAGCCACACCTCC 198741 198740 GAAAGAAACAAAGTCTACCACGACGACTACTCGCTCCAGATTGTTCCATTTTTACTAATGATGCGCGCAT 198671 198670 GACCCTGTTCTAACAATAAATATGCCTGTACAAACAAACAGGCTCAGCTCTAATGAGCTCATCCATTCCC 198601 198600 CGGGGTTTCTTGGTGCAGTAGCACGCTTCTGGCAGGTGTGTGTAGTCTTGCCGACATGCTGGGCCGGTTT 198531 198530 CGAATAGCTAATGGGGACTCTTGGGGTACAAGTAGCGCTCGTATGCTTCAGATTATATTGGAATAGCGAT 198461 198460 GCTAGTATGCGGATATATAGGGGTATGTGAACTACAAAGGCCAAAAGGCTAGGAATCTTGGGGACAGACG 198391 198390 CACACTTACACCATGAACAGATACAATTCTTCGCCGAACCCTTCCATCGCATGTTTTTCCTGGATAACCT 198321 198320 CGCGATCAACTACCCCCACGCCGAGATCGAGCGCGTATCGGTAACGTGGCTGTTTATCTACGCGGCAGCC 198251 198250 GTGCCATTGGGTATACTTGTTGTATGGGCTCTTGCATTCCGCCCAGGAACACACAAAGCGCACGTCACTA 198181 198180 TTCTCGGGCTGGTAATCAGTCTGATTCTCACAAGCTTCATCACCGATGTGATCAAGAACGCCGTCGGCAG 198111 198110 ACCCCGACCCGACCTCATTGCGCGATGCAAACCCGCACCTGGCACCCCGGCCCACCAGCTCGTCACGTAC 198041 
198040 GAAATCTGTACTGAAACAGATCATCATACCTTGCACGATGGATGGCGCAGTTTTCCCAGCGGTCATAGCA 197971 197970 GTTTCGCCTTCGGCGGACTGGGTTACCTTTCCCTCTTCATTGCAGGCCAATGCCACGTTTATCGTCCCCG 197901 197900 TGCCGACCTCGCTCGCGTCCTGTTGGCTCTTATACCTTTGCTCGGCGCCGCGCTCATCGCCATTTCCCGC 197831 197830 TGCGAAGACTACAGACACGATGTCTACGACGTTACTGTCGGGTCGTTGATCGGAATGACAATTGCGCATT 197761 197760 ATACATACAGGAGGTATTATCCTGCTCTCAGGCACAGGCTGTGTGCTACGCCGTTTCCTAATCCTGCGGA 197691 197690 TGACAAGGGATGGGGGAAGGTCAAAGGGGATGAGGAAAGTTTGAGAGATGTGCAGGAGTTTGAGTTGAGT 197621 197620 GAGTTTGAAGAGGAGGAGAGGGAAAGCGGTGAGGGGAGGCCGTTGAATGGAGGGAGGAGACAGCATTGA 197551 197550 GAGTACAGTGGTGATTMGTGCTTMATGATTTGATMAAAGTGTTTTGTAACGCGTATAATCATGGC 197481 197480 TTTCTCGTGTTGTTCGTTGGTTGATGTCTGCAAGACGTCCTATGAGGTATGTAGATGGGCAGAGAC 197411 197410 CTATGGCTTGTTICATGAGGACTGCCTGTTCTTTAGTCCACGTAGAGGACTAAAT 197352

\title{
HPO7 scaffold_14:381359-382662
}

\begin{abstract}
382862 CAACGCTCGTCCTCCAAGACTCGCCGCACAGCGCTTGATACACGTGCCAAGGTCAATTGCGTCTAAGCCC 382793 382792 CCGTCTATGCGCCCGTCATCTTGATCCGTCCCGGACGTGGCGTGCTCGTGCCAGCTGCTCGACTGAACA 382723 382722 TTTACCTCGCCTTGCCTCCGCCTCGCTGCTGGCAGCCCCGTCTTCTTCACCGCGGCAAACATGCAGTCGT 382653 382652 TCAAGACCATGAGTCGGCCGTCGTCGCGCCTCATTGCCTCCTATATCTTTGACTGGATCGTCATCATCGC 382583 382582 CATTGCTGCCGTCGCCGGCGGCTGGGAATTCCTCGAGCCCTTCCGCCGACCCTTCTCTCCCGTCGATCTC 382513 382512 AACATCTCCTACCCGCATCAGTTCAACGAAAAGATCCCCACATGGCTGCTTGTCGTCGTCTCGCTTGTCA 382443 382442 TCCCTGCCGCCATCATCCTGGTCGTCTGTCTTGTCTTTGTCCCGGGTCCAACCGCTGAGCGTGGAACGCC 382373 382372 AAAGTCGCTCATTTGGAGGAGGAAGCTCTGGGAGTGGAACACGGGATGGATGGGCCTGGCTCTCTCCCTT 382303 382302 GCCACGGCCTTTTTGATCACCCAGGGTATGAAGAACTTGTTTGGAAAACCGAGACCGGATCTGCTGTCGA 382233 382232 GATGCAAGCCCGACCTCGATCGCATTGCCGAATTCGCCATCAATCCCATTGTCGGAGACATCTTTGACCC 382163 382162 GGCCTGGGTGCTCGTTACTTCGGGTATCTGTACCCAGACCGACAACGATCTCCTGAAGGACGGCTTCAAG 382093 382092 TCGTTCCCCAGCGGACACTCTAGCTGTAAGCCATCTCGTCTTCCCTTTCTTTCGTACCCGTTCACTAACC 382023 382022 CAGTACTCCTGCAGTCTCATGGGCCGGCCTGCTCTACCTCACCCTCTTCCTCGCCTCCAAATTCTCCGTT 381953 381952 GCAATCCCCTTCCTCCCGCACCGCCCCTTCTCTACGAACCCGGCCTACACCTCGGCTGTGGCTCCTTCCA 381883 381882 ATCTGAAGAGACAAGCCACCCTCCCCATGCACAAGCAAGACACCTCCCTCTCCTCCCCGAACTCGTACGC 381813 381812 CGATGATGCCGTAGTCCCCATCCGCTACCAAAACGCCGCACCACCCGTCTACACGCTCGTCCTCATCCTC 381743 381742 GTCCCCATCTGCGCCGCAATCTACATTACTAGCACCCGCTACACCGACTTCCGCCACTTTGGCTTCGACA 381673 381672 TGCTCTTCGGCTCCCTCATTGGCATCACCTGCGCCTGGTTCTCCTTCCGCTGGTACCACCTGCCCATCAC 381603 381602 GCGGGGTGCAGGCTGGGCCTGGGGTCCCCGCAGCTACCAGCGCGCCTGGGGCATTGGCGTCGGCCGCGGC 381533 381532 TCGTACGTCGGCACAGAGGGATGGAGCAAGGCCAGGAAACGCACGGATACACGTGCTGCTGTGCAATCGG 381463 381462 TCGACGAAAGCGAATTGGGCGTCTTGAATGCAAATGGTGTGCCGCATGCGGGGAATCCCCCTAGTTCTAG 381393 381392 ACAGTCGAGGACAGCAGGCTCGCACGATGTTTAGAATATGCATGCAAAATACTCTAGTTGAAACCTGCCA 381323 381322 TCCTGAATAGTTATTATATACAAGAGAAAAAAAGAGGCCTCGCTACGTTCCGCAGGTGAAAATGGCAAAA 381253 381252 CAGAACCAGATTTTATATACGAGACGACTTACATGATGAATTGTAATTAGATATCCCTGTCCAATGCAC 381183 381182 CTTTTTATTTATTCTTGATAT 381159
\end{abstract}

\section{HPO8 scaffold_3:1031353-1032149}

1031153 AAAGAACCCTTGAGAGGCCCATTGTGAAGAgCAGAGTGACAGTATGCTAGAATCAGCAAAGTGATGCC 1031222 1031223 CTTCCCGGCACTATTCCAGACCATGGAGGGGGTGGGGGCGCGCCTTGCACGCGCCACGCCAAGGCCGGCA 1031292 1031293 GGGTCTCGCGCGGCTATGCGCCACCATCAACATCATCGTCATTCACCTTGCAGCTCCAGCATGGACGGCC 1031362 1031363 CCCCGCTTGCCTCGCTTTCCCTTACCCATGTGCACTATGTTGGTAGACCCAGATGGCTGTGTCGCGCACA 1031432 1031433 GTGCTGACATGCTTAGAACCCAGCAGACCGCGTCTCTTTCTTGTGCGCATGGCTCGCCCTCGTACCGCAG 1031502 1031503 GCGTTGTGTGTAGTCTATGCGACGCTGATATGGTCGAACCGCGAGATTGAGATCTTCCTCATGTTCGCAG 1031572 1031573 GGCAAATGTCCTGCGAAGCCCTCAATTGGGTGCTGAAGAGATACATCAAGGAAGAGCGACCACGGGGTAT 1031642 1031643 GCGCAGAGCACTCTAACTTCTCACCTTCCAAACAATGTACTGACGGCTACACCTCCAGAGATGCATGGCA 1031712 1031713 AGGGCTATGGAATGCCTTCGTCACATGCACAATTCGTCTCCTTCTTCTCTGTCACTCTCACCCTCTTCCT 1031782 1031783 CCTTTTCCGCCACGTCCCGCACCCTACCGATACCCACACCCCCTTCTCCTTCGGTGGTCGCCTTGTCCTC 1031852 1031853 TCGCTTCTCGCACTAGCCAGCGCCGGTGCTGTAGCCGTCAGTCGTATTTATCTGAGCTACCACACCCCGA 1031922 1031923 AGCAGGTTGCAGTTGGTTGTGGAGCTGGAGCCGTTTTTGCGTTGGTATGGTTCTTGTTCACAACATATCT 1031992 1031993 GCGGAGAGCTGGTTGGATTGAGTGGGCGCTCGAGACATGGCTCTTTAGAGCACTTCGTGTCAGAGATCTC 1032062 1032063 GTGATACAAGAGGACTTGGTTGATTCTGGGTGGGCAAGATGGGAAGACAGGAGGAAGCGACAGGTGCTTG 1032132 1032133 TGAATCAAGGCAAGAAGCTGAAGTAAACTTTGGTACATACTCGGTCTATTTAACCCTAAGCATACGCTAT 1032202 1032203 TGCCAGTAATATCCGTCACCTGGACGCTGTTATAGGTACATGAGACCGTTTCAAGAATCTAGACTAGAC 1032272 1032273 TACCGTACCGACAGCATGCAACAGCCGAAGATATTTGATTCATCTTTCTGACATTCTTGACCAGCAGTG 1032342 1032343 CTGTTCC 1032349

\section{HPO9 scaffold_9:213955-215764}

213755 CAGCTCGGCCGTTCCGAGCCAGCGCTTACCTTAGCCCATGCGCAATACACTGCCAAACACTACTACACAG 213824 213825 CAGCACAGCAAACCACCACCACGACCACTACCCCTTTGCGCGCACGCCCGCCCCGCCCCGCGCCTGGACA 213894 213895 TGCACAGTCGACTGAACCGCCTTCGTCTCCGCTGCAACTGTTGCGACCCTCGCCGCCGCCATGCACCCGC 213964 213965 CGCAACATCAACATGAGGCGGGGCCCCAGCCGGACTCGACGGCTCCGTTGAAACCCAAGTTGGACGCAGG 214034 
214035 CAATCAGGGCCACGATCACTATGCCCAGCGGCTGCCCAAATGGCGCAATTCGCTGCGAAATCGCCTCATT 214104 214105 CCCATTGTGCGCTGGGAGACGCCGTGGCTGGCGCTGCTGCAGGACAAGCTGCGCTCGCCCTTCCTCGACT 214174 214175 CGTACTTTGCCTACACTGCCAACCTCGGCACCCACACCTTCTTCATGGTCTTCCTGCCCATCCAGTTCTG 214244 214245 GTGCGGCTACACCAGCGTAGGCCGAGCGTACGTCGCGCGCTGTTGTCCTTGGCCGTACTGCCATGTCTGA 214314 214315 CGTGCACAGGACTGTCTTCATGCTCGCCGCCGGCGTCTACTTCACCGGCTTCTTGAAGGACCTACTCTGC 214384 214385 TTACCGAGGCCGCTATCGCCGCCTCTTGCTCGCATCTCCATGTCTGGTTCCGCTGCGCTTGAATACGGAT 214454 214455 TCCCCTCGTCTCATTCGGCCAATGCCGTCTCCGTAGCCTTCTACGCCATTTACATGTTGCGCCAGTCTGC 214524 214525 CCAAGAGGGCAGCACTAACCTAAACATGGGCCTCCAGGCGCTCTTTTACTTTTATGCACTGTCCATCATC 214594 214595 GCCGGCCGCTTGTACTGCGGCATGCACGGTTTCCTCGACGTCATAGTGGGCAGTGTTATGGGCGCGCTCA 214664 214665 TCACGGCATTCCAACTCGTATATGGCGACTGGATGGACTCGTGGGTCTTTAGCGGCAATTCCCTGCATAT 214734 214735 CTTTATCGCTACCCTGGTAATCTGTGTTCTTGTCCGCGTCCATCCGGAGCCTGCCGATGACTGTCCTTGC 214804 214805 TACGACGATAGCGTGTCGTTCGCTGGTGTCGTCATAGGCATTAACCTTGGTGCCTGGCACTATGCCCAAA 214874 214875 CCGGCTACGCCCTGCAAGATGCATATCCGTCTTCGGTCCCCTTCAGCTTGGAAGAGATGGGATGGTTGAA 214944 214945 AGCAATGATTCGTATCGTCTTGGGTGTCGTTGTCATCTTCGTCTGGAGAGCGACCATGAAGCCTGCTCTG 215014 215015 TTCACCGTACTGCCTCCCATCTTCCGTTTGCTTGAGCAAGCTCGTTGGAATATGCCCCGTGCCTTCTTCT 215084 215085 TGAACGCTTCCAAGTACAGCTCCATTAAACCGTTCGCAGATGACGATAATGTCATTCCACCTGCTTCGGA 215154 215155 GCTGCCGCATATGCTGAAGAACCTCGCACACCCACGTAAGCGGTCCGTCTCGGTTGGTCCACAATCTGCT 215224 215225 GCAGATGCATATGAGACGCTCGCATACCGCAACCGTCGGCGACGAGAAAGCGTCAACTCGTTGGATGGCG 215294

215295 CTCTTCCAGAGAACTCCACCTGGGTCCCTAGTTCAACACCTCTACACACGCCCAAAGTGGAGAAATCGGA 215364 215365 CCCGCTGCTTGGTGCCGGCCTCCTGCCAACACCAATGGCGTCTCGAGTACATTCGTATGAACAGATGATG 215434 215435 GGCACTGGTAAAGTGCAACTGCCCGAGAAGAGCACAATGACGCCCCCAGAGAGCGACACAGACGTTGCAG 215504 215505 GCAATGTCTATGAAGTCACGCAGGAGCCGACCGAAGAGGAGAACGAGAAGCGCGAGATTTTCATGAAGCT 215574 215575 GACGACGCCACGAGTACGATACGACGTTGAGGTTGTAACAAAGTTAATCGTTTACGCTGGTATGTCAATC 215644 215645 ATGTCAAGCACAATAGCCCAAACGGACTGCTAATCTACATTAGGTATTGCATACATAGCGGTTGCAGGAA 215714 215715 ACCCTATTTTGTTCGAGTTCCTGGGATTAGGCATGGGCATCGAGGCATAGTTTACCTGGCTCTCATATTT 215784 215785 CGTTTTGCTCTTTGTACATATACCAGTATTAGTTTATTGCTCCTAGATGGGATGCACCTAATAAAGTATT 215854 215855 CTTCTTCCAGTGCATGAGGTTCAAGATGCTCGCGGAACTTTGCACCAACATCCACCAACACGAATCATGG 215924 215925 TAAGAATTAAAATTMAAAGAAAAAAAAGAAAAAAAGG 215964 